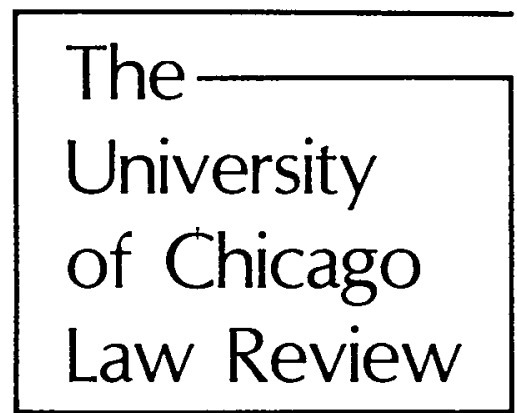

1991 by The University of Chicago

\title{
The Plaintiff s' Attorney's Role in Class Action and Derivative Litigation: Economic Analysis and Recommendations for Reform
}

Jonathan R. Macey $\dagger$ and Geoffrey P. Miller $\dagger \dagger$

Table of Contents

Introduction $\ldots \ldots \ldots \ldots \ldots \ldots \ldots \ldots \ldots \ldots$

I. The Role of the Entrepreneurial Attorney ........

A. The Economic Rationale for Class Action and

B. The Role of the Entrepreneurial Attorney in Class Action and Shareholder's Derivative Suits

1. The economic theory of agency and its application to standard litigation ...........

a) Monitoring ..................... 13

b) Bonding $\ldots \ldots \ldots \ldots \ldots \ldots \ldots \ldots \ldots \ldots \ldots \ldots \ldots \ldots$

c) Incentives ................... 17

d) Residual loss ................ 19

2. Application of agency cost theory to class and derivative cases.

$\dagger$ Professor of Law, The University of Chicago. The John M. Olin Foundation provided financial support for Professor Macey's work on this project.

t† Kirkland \& Ellis Professor of Law, The University of Chicago. The Sarah Scaife Foundation provided financial support for Professor Miller's work on this project.

The authors would like to thank Albert W. Alschuler, Douglas G. Baird, John C. Coffee, Jr., Richard A. Epstein, Michael W. McConnell, Thomas R. Meites, Daniel N. Shaviro, participants at a University of Chicago Law School Work-in-Progress Workshop and a New York University Faculty Workshop for helpful comments, and Amanda Newton and Erika Samuels for valuable research assistance. 
a) Monitoring ................. 19

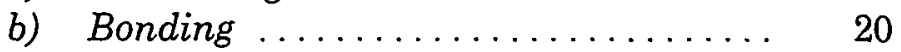

c) Incentives.................. 22

II. Regulations Allocating Litigation Authority ....... 27

A. Notice and Opt-Out Rights in Class Actions .. 27

B. Control of Derivative Litigation ........... 34

1. Director demand ................. 34

a) Demand required cases........... 35

b) Demand excused cases ............ 37

2. Special litigation committees ........... 38

C. Conflicts Between Representative Plaintiffs and Plaintiffs' Attorneys ................... 41

D. Judicial Review of Settlements and Fee Requests .......................... 44

1. Judicial review of settlements ......... 44

2. Judicial review of fee requests ......... 48

a) Lodestar method ................ 50

b) Percentage method ................ 59

III. Regulation of the Named Plaintiff ............ 61

A. General Defects of the Rules ............. 63

1. Enforcement by defendants ........... 63

2. Reduction in the supply of representative plaintiffs $\ldots \ldots \ldots \ldots \ldots \ldots \ldots \ldots \ldots . \ldots 6$

B. Typicality ...................... 69

1. Obtaining class or derivative status ...... 69

2. The contemporaneous ownership rule in derivative suits . . . . . . . . . . . . . 76

3. Justiciability considerations . . . . . . . . . $\quad 79$

C. Adequacy ....................... 84

1. Financial support of the litigation ....... 85

2. Competence of representation .......... 91

IV. Plaintiffs' Attorney's Ethics . . . . . . . . . . . . . . . 96

A. Maintenance . . . . . . . . . . . . . . . . . 97

B. Solicitation $\ldots \ldots \ldots \ldots \ldots \ldots \ldots \ldots \ldots \ldots \ldots$

C. Fee-splitting . . . . . . . . . . . . . . . . 102

D. Appearance of Impropriety .............. 103

E. Appropriate Use of Ethical Considerations .... 105

V. An Auction Approach to Class Action and Derivative Litigation ... . . . . . . . . . . . . . . . . . . . . . 105

A. Description of an Auction Model .......... 106

B. Advantages of the Auction Approach ........ 108

C. Problems With the Auction Approach ....... 110

Conclusion ........................... 116 


\section{INTRODUCTION}

Plaintiffs' attorneys in class action and derivative suits occupy an uneasy place in the American legal system. The traditional image of the lawyer is of an independent professional providing advice and advocacy on behalf of a client. The attorney, in this view, is an agent of the client and subject to the client's control in all important matters. Plaintiffs' class action and derivative attorneys do not fit this mold. They are subject to only minimal monitoring by their ostensible "clients," who are either dispersed and disorganized (in the case of class action litigation) or under the control of hostile forces (in the case of derivative litigation). Accordingly, plaintiffs' class and derivative attorneys function essentially as entrepreneurs who bear a substantial amount of the litigation risk and exercise nearly plenary control over all important decisions in the lawsuit.

The absence of client monitoring raises the specter that the entrepreneurial attorney will serve her own interest at the expense of the client. The existing regulatory system attempts to prevent such abuse-and to reduce what have been termed "agency costs"-in three principal ways. First, it allocates certain elements of litigating authority to persons other than the plaintiffs' attorney-absent class members, managers of corporations involved in derivative suits, representative plaintiffs, and the courts themselves. Second, it contains a number of special features ostensibly designed to weed out inappropriate representative plaintiffs. The representative plaintiff must assert claims that are typical of the claims being asserted, and must represent the class or corporation adequately. Third, plaintiffs' attorneys are subject to applicable rules of legal ethics that purport to constrain the attorneys' behavior in order to safeguard clients' interests.

We believe this regulatory structure is poorly designed in a number of respects, particularly when applied to "large-scale, small-claim" litigation in which the overall liability is large but the individual interests of the class members or corporate shareholders are small. The existing regulations are extraordinarily ineffective at aligning the interests of attorney and client; indeed, they often impair the interests of the clients they are ostensibly designed to protect. Many regulatory shortfalls can be traced ultimately to a single fundamental error: the inappropriate attempt to treat entrepreneurial litigation as if it were essentially the same as standard litigation, in which the client exercises substantial influence. Even when the regulatory system acknowledges that en- 
trepreneurial litigation poses special problems, it frequently attempts to resolve those problems by forcing class action and derivative litigation back into a standard model. The inevitable result is regulatory failure, simply because entrepreneurial litigation cannot be transformed into the traditional model even by brute regulatory force.

We propose revising the regulatory system in a number of ways. Our proposals have a common goal: to control agency costs with sensible rules that take into account the fact that the plaintiffs' attorney-not the client-controls the litigation. For example, the existing regulatory regime requires that all absent class members be given notice of a pending damages action and an opportunity to opt out of the suit-regardless of the size of the claim. ${ }^{1}$ The high cost of notifying absent class members when potential recovery is very small deters entrepreneurial attorneys from bringing meritorious suits. Thus, the rule harms, rather than protects, absent class members. We suggest that notice of class action in such cases should not be required for small claimants in advance of some authoritative disposition on the merits.

Another problem area is judicial review of settlements and fee requests, which is often haphazard, unreliable, and lacking in administrable standards. Although review of settlements is necessary so long as the entrepreneurial attorney's interests differ from those of the client, we suggest that review could be improved by the use of guardians ad litem to represent the interest of the class in largescale, small-claim cases. As to fee requests, we join other recent commentators in finding that, despite serious drawbacks, a percentage-of-recovery method (in which the plaintiffs' attorneys are awarded some percentage of the class recovery as fees, either on a fixed percentage basis or according to some more complex sliding scale) is superior to the currently favored lodestar approach (which allows attorneys to recover according to the number of hours they spend on a case). The lodestar approach has three principal, related defects: it involves enormously burdensome circulation costs; it encourages attorneys to exaggerate their hours; and, because it guarantees that the attorneys will receive their fees if successful, it fails to give plaintiffs' attorneys the proper incentive to strike a settlement agreement that maximizes recovery for the plaintiff class.

1 See Phillips Petroleum Co. v Shutts, 472 US 797, 812 (1985); Eisen v Carlisle \& Jacquelin, 417 US 156, 173-77 (1974). 
We also criticize the current system for regulating the identity of the named plaintiff. The existing requirements of typicality (under which the named plaintiff's claim must be similar to that of the other class members or shareholders) and adequacy (under which the named plaintiff must be capable of competently and adequately representing the absent class members or the corporation $)^{2}$ often exclude appropriate representative plaintiffs and reduce artificially the supply of attorneys able to serve the class or corporation. Given that the named plaintiff has little control over how the suit is conducted, the analysis should focus not on the appropriateness of the named plaintiff but rather on the reliability and competence of the plaintiffs' attorney.

Further, the regulatory system should acknowledge explicitly what is already the case, namely that ethics rules on solicitation, maintenance, fee-splitting and the acceptance of impropriety have virtually no current force or rationale in the large-scale, smallclaim setting and are routinely circumvented with only the thinnest veneer of compliance. We recommend that these ethics rules be jettisoned in this group of cases. Instead of the current attempt to force the ethics analysis into standard, but inappropriate, doctrinal categories, the regulatory system should investigate whether the attorney's behavior poses real dangers to the interests of the class or corporation.

Underlying many of these observations is a more basic critique of the existing regulatory system's requirement that there be an actual identified individual plaintiff in large-scale, small-claim cases. Because these cases are dominated by entrepreneurial attorneys, the identified plaintiff operates almost always as a mere figurehead. The named plaintiff does little-indeed, usually does nothing-to monitor the attorney in order to ensure that representation is competent and zealous, or to align the interests of the attorney with those of the class or corporation. On the other hand, the requirement that there be an actual named plaintiff artificially limits the supply of attorneys able to bring large-scale, small-claim cases because in many cases "appropriate" representative plaintiffs are hard to find. The quality of representation is thereby diminished, and the private enforcement of law impaired. Further, attor-

2 FRCP 23(a) governs class actions. See FRCP 23(a)(3) (claims or defenses of representative plaintiff must be "typical of the claims or defenses of the class"); FRCP 23(a)(4) (the representative parties must "fairly and adequately protect the interest of the class"). FRCP 23.1, which governs derivative litigation, has an analogous adequacy requirement but does not contain an analogous typicality requirement. Courts insist on typicality when applying R.ule 23.1, however. See Davis v Comed, Inc., 619 F2d 588, 592-97 (6th Cir 1980). 
neys are routinely forced to circumvent ethical restrictions on solicitation and maintenance in order to obtain named plaintiffs as their ticket into profitable litigation. We believe that the costs of requiring an actual named plaintiff greatly outweigh the benefits. Accordingly, we recommend that actual, identified named plaintiffs not be required in large-scale, small-claim litigation. Instead, a plaintiffs' attorney should be allowed to bring "Jane Doe" or "Richard Roe" complaints on behalf of a class or corporation.

Although we make several recommendations for-ways in which the existing regulatory structure could be changed to deal more effectively with the unique problems posed by entrepreneurial litigation, we believe that a more fundamental change may be in order. We draw on the economic theory of agency costs to suggest that the special problems of entrepreneurial litigation could be substantially overcome if the legal system were to allow some form of auction for plaintiffs' claims, under which attorneys (and others) could bid for the right to bring the litigation and gain the benefits, if any, that flow from success. A pure form of auction would simply sell the plaintiffs' claims outright to the winning bidder, with the proceeds to be distributed immediately to the class or corporation. Under such an approach, the winner of the auction would have litigation incentives that are very similar to those which a claimholder would have in traditional, two-party litigation. There would be no need for any rules on typicality or adequacy of representation or for judicial scrutiny of settlements and fee awards. Class members would receive a certain and quick recovery rather than an uncertain and delayed one. The result would be more effective private enforcement of the law. Other possibilities we discuss involve partial bids or bids for lead counsel rights based on the percentage of the recovery that the attorney would be willing to take as a fee; these may be more feasible to implement, although they retain some of the problems of misalignment between the interests of the attorney and client. ${ }^{3}$

\footnotetext{
${ }^{3}$ District Judge Vaughn Walker of the Northern District of California has recently conducted an auction of lead counsel rights based on fee percentages. See In re Oracle Securities Litigation, 131 FRD 688 (N D Cal 1990) (setting up the bidding process); In re Oracle Securities Litigation, 132 FRD 538 (N D Cal 1990) (awarding lead counsel rights to one of four bidders). Even more recently another distinguished district court judge, Milton I. Shadur, expressed strong support of the auction approach, referring to Judge Walker's opinion in Oracle Securities Litigation as "extraordinarily interesting" and observing that "[i]n the best tradition of imitation as the sincerest form of flattery, if a like situation were to present itself to this court on another occasion, it would give serious consideration indeed to following Judge Walker's lead at the very beginning of the litigation." In re Telesphere International Securities Litigation, 1990 US Dist LEXIS 16665 n 12 (N D Ill). See also
} 
We do not advocate the auction approach as a panacea to the problem of attorney-client conflicts in class and derivative suits. There are a number of problems with an auction approach, including difficulties in defining the claim to be sold, the possibility that adequate financing will not be available to bidders, the problem of obtaining the cooperation of class members whose claims have been sold, and issues of consolidation of cases brought in different jurisdictions. Although we recognize these problems as serious, we believe there is considerable merit to the auction approach.

The Article is structured as follows. Part I discusses the economic theory of agency as applied to the attorney-client relationship, addresses the special role of the entrepreneurial attorney in class and derivative suits, and illustrates the important differences between class or derivative actions and standard client-dominated litigation. Part II addresses the regulations allocating litigating authority between plaintiffs' attorneys and other interested parties such as absent class members, corporate managers in derivative suits, the representative plaintiff, and the courts. Part III considers the rules governing the selection of representative plaintiffs, including the requirements of typicality and adequacy. Part IV considers the regulation of the plaintiffs' attorney's ethics. Finally, Part $V$ analyzes the costs and benefits of an auction approach to entrepreneurial litigation in large-scale, small-claim cases.

\section{The Role of the Entrepreneurial Attorney}

Over the past decade a number of scholars, including most prominently Professor John Coffee, have recognized that the single most salient characteristic of class and derivative litigation is the existence of "entrepreneurial" plaintiffs' attorneys. ${ }^{4}$ Because these

Janet Cooper, Do the Merits Matter? A Study of Settlements in Securities Class Actions 208 (John M. Olin Program in Law and Economics, Stanford University Law School, 1990) (on file with U Chi L Rev).

- See John C. Coffee, Jr., Rethinking The Class Action: A Policy Primer on Reform, 62 Ind L J 625 (1987); Coffee, The Regulation of Entrepreneurial Litigation: Balancing Fairness and Efficiency in the Large Class Action, 54 U Chi L Rev 877 (1987); Coffee, Understanding the Plaintiff's Attorney: The Implications of Economic Theory for Private Enforcement of Law Through Class and Derivative Actions, 86 Colum L Rev 669, 676 (1986); Coffee, The Unfaithful Champion: The Plaintiff as Monitor in Shareholder Litigation, 48 L \& Contemp Probs 5, 12 (Summer 1985); Coffee, Rescuing the Private Attorney General: Why the Model of the Lawyer as Bounty Hunter Is Not Working, $42 \mathrm{Md} \mathrm{L} \mathrm{Rev} \mathrm{215,} \mathrm{235-36}$ (1983). The first commentator to refer to plaintiffs' attorneys in class and derivative suits as "entrepreneurs" appears to have been Kenneth Dam. See Kenneth W. Dam, Class Actions: Efficiency, Compensation, Deterrence, and Conflict of Interest, $4 \mathrm{~J}$ Legal Stud 47, 60 (1975); Dam, Class Action Notice: Who Needs It?, 1974 S Ct Rev 97, 121. 
attorneys are not subject to monitoring by their putative clients, they operate largely according to their own self-interest, subject only to whatever constraints might be imposed by bar discipline, judicial oversight, and their own sense of ethics and fiduciary responsibilities. In this section we begin by describing the economic rationale for class action and shareholder's derivative lawsuits. We then discuss the role of the entrepreneurial attorney in such lawsuits by placing it in the context of the economic theory of agency, and by contrasting it with the role of the attorney in standard litigation in which the client exercises a substantial degree of influence over the attorney's actions.

\section{A. The Economic Rationale for Class Action and Shareholder's Derivative Litigation}

Any theory of the entrepreneurial attorney requires an initial investigation into the dynamic structure and economic rationale for the two procedural contexts within which such attorneys flourish. In both the class action and the shareholder's derivative suit, the attorney's client is not actively involved in the conduct of the litigation on the plaintiff's side. But in other respects these devices are quite different in theory and rationale.

The class action is a tool for overcoming the free-rider ${ }^{5}$ and other collective action ${ }^{6}$ problems that impair any attempt to organize a large number of discrete individuals in any common project. These kinds of problems are prevalent in situations when a large number of people have been injured by another person's conduct, but when the injury to many of these individuals is small. In the absence of a class action device, such injuries would often go unremedied because most individual plaintiffs would not themselves have a sufficient economic stake in the litigation to incur the litigation costs. Of course, some particularly aggrieved individual might attempt to bring a large group together in a single lawsuit by using standard joinder and intervention devices. ${ }^{7}$ But bringing large numbers of additional parties in by this method would be very

- Freeriding, as the name implies, simply refers to a situation where a person can obtain a benefit (or avoid a cost) without paying for it. See Iain McLean, Public Choice: An Introduction 11-12 (Basil Blackwell, 1987) (discussing connection between freeriding and the problem of public goods); Mancur Olson, Jr., The Logic of Collective Action 1-2 (Harvard, 1965).

- Collective action is used in the public choice literature to refer to any procedure for making decisions by groups of people. See McLean, Public Choice at 11 (cited in note 5). See generally Olson, The Logic of Collective Action (cited in note 5).

7 See FRCP 20 (permissive joinder of parties) and FRCP 24 (intervention). 
costly. Organizing the conduct of litigation with large numbers of additional parties would be a nightmare. The organizer, moreover, would have no effective way of obtaining reimbursement from other plaintiffs for these costs.

The class action procedure partially overcomes these difficulties by providing an effective and inexpensive procedure for joining large numbers of individual plaintiffs. ${ }^{8} \mathrm{~A}$ representative plaintiff can file an action and seek class certification, which has several prerequisites. Among other things, the class must be "so numerous that joinder of all members is impracticable"; there must be "questions of law or fact common to the class"; the claims or defenses of the representative parties must be "typical of the claims or defenses of the class"; and the representative party must "fairly and adequately protect the interests of the class." In addition, the representative plaintiff must establish the prerequisites for one of three separate subcategories of class action. The role of the entrepreneurial attorney is most prominent in the so-called " $(\mathrm{b})(3)$ " class action, in which "questions of law or fact common to the members of the class predominate over any questions affecting only individual members, and ... a class action is superior to other available methods for the fair and efficient adjudication of the controversy."10

- See Deposit Guaranty National Bank v Roper, 445 US 326, 338 (1980) ("[t]he use of the class-action procedure for litigation of individual claims may offer substantial advantages for named plaintiffs; it may motivate them to bring cases that for economic reasons might not be brought otherwise"); United States Parole Commission v Geraghty, 445 US $388,402-03$ (1980) (justifications for the class action "include the protection of the defendant from inconsistent obligations, the protection of the interests of absentees, the provision of a convenient and economical means for disposing of similar lawsuits, and the facilitation of the spreading of litigation costs among numerous litigants with similar claims"); Richard A. Posner, Economic Analysis of Law 536-37 (Little, Brown, 3d ed 1986) (class action achieves economies of scale in litigation); Arthur R. Miller, Of Frankenstein Monsters and Shining Knights: Myth, Reality, and the "Class Action Problem", 92 Harv L Rev 664 (1979) (emphasizing social benefit of providing small claim adjudication); Judith Resnik, From "Cases" to "Litigation" (unpublished manuscript; on file with U Chi L Rev).

- FRCP 23(a). The rule also permits class actions in which many individual defendants are joined; these cases are uncommon, however.

10 FRCP 23(b)(3). A second type of class action involves cases in which the prosecution of separate actions would create a risk of inconsistent adjudications with respect to individual members of the class, thus establishing incompatible standards of conduct for the party opposing the class, or where adjudication with respect to individual class members would impair or preclude the ability of nonparties to protect their interests. See FRCP 23(b)(1). A third type of class action involves cases where the party opposing the class has acted or refused to act on grounds generally applicable to the class, thereby making injunctive or declaratory relief appropriate with respect to the class as a whole. See FRCP 23(b)(2). 
The economic rationale for the (b)(3) class action-as a method for overcoming free-rider and other collective action problems-stands in sharp contrast to the rationale for the shareholder's derivative suit. ${ }^{11}$ Shareholder's derivative actions are not premised on collective action problems in the litigation. On the contrary, they presuppose the existence of a corporate form that is already organized to overcome such collective action problems. The corporation has standing and is fully competent to bring legal actions to redress injuries to its rights. The problem, rather, is with collective action within the corporate form itself. As scholars since Berle and Means have observed, ${ }^{12}$ corporate managers typically have only a small ownership stake in the firms they manage. ${ }^{13}$ Thus, their interests deviate from those of shareholders: they may prefer to consume excessive perquisites or practice their golf whereas shareholders would want them to work diligently at maximizing profits. ${ }^{14}$

The shareholder's derivative suit is one of many devices in corporate law for controlling these conflicts between managers and shareholders. Many cases arise in which a corporation has an enforceable legal claim against others for harm to the corporation. Like other matters affecting the corporation, pursuit of the claim is left initially to the managers. But if the suit would potentially harm the managers' personal interests, the managers may be unwilling to prosecute the claim, even when doing so would serve the best interests of the corporation. The classic case is the action for breach of fiduciary duty against corporate directors. Obviously the directors cannot be trusted to cause the corporation to sue themselves. The derivative action allows a representative shareholder in such circumstances to take over the litigation from recalcitrant managers and prosecute it on behalf of the corporation. Unlike the

"For a discussion of policies underlying the derivative remedy, see John C. Coffee, Jr. and Donald E. Schwartz, The Survival of the Derivative Suit: An Evaluation and a Proposal for Legislative Reform, 81 Colum $L$ Rev 261, 302-09 (1981) (expressing concern for the long-range viability of derivative litigation).

${ }_{12}$ Adolf A. Berle, Jr. and Gardiner C. Means, 2 The Modern Corporation and Private Property (CCH, 1932) (separation of ownership and control in large corporations).

13 This fundamental observation underlies not only the "liberal" theory of the corporation which stems from Berle and Means, see, for example, Melvin Aron Eisenberg, The Modernization of Corporate Law: An Essay for Bill Cary, 37 U Miami L Rev 187 (1983) (pointing to management abuse stemming from separation of ownership and control), but also the law and economics analysis of corporate law, see, for example, Frank H. Easterbrook, Managers' Discretion and Investors' Welfare: Theories and Evidence, 9 Del J Corp 540 (1984) (noting various devices in corporate law and finance to control actions by managers who do not serve shareholder interests).

${ }^{14}$ As we discuss at length below, see notes 53-79 and accompanying text, this problem is analyzed in economic terms under the rubric of "agency costs." 
class action, in which the relief is given to the plaintiff class members, any relief recovered in a derivative action (net of expenses including attorneys' fees) is returned to the corporation.

In federal court litigation, derivative actions are controlled procedurally by Rule 23.1, which applies to derivative actions "brought by one or more shareholders ... to enforce a right of a corporation .... the corporation ... having failed to enforce a right which may properly be asserted by it."15 The complaint must state "the efforts, if any, made by the plaintiff to obtain the action the plaintiff desires from the directors ... and, if necessary, from the shareholders ...., and the reasons for the plaintiff's failure to obtain the action or for not making the effort."16 Like the class action plaintiff, the derivative plaintiff must "fairly and adequately represent the interest of the shareholders," and any settlements are subject to judicial approval. ${ }^{17}$ Similar rules apply for state court derivative suits. ${ }^{18}$

Both the class action and the shareholder's derivative lawsuit can thus be explained and rationalized in terms of modern economic theory. This view does not mean, however, that such litigation is necessarily beneficial either to the putative plaintiffs or to society. It is clear that class action and derivative suits do contribute to private enforcement of certain laws. But this begs the question of whether the laws themselves are ones that ought to be enforced, or ought to be enforced by private litigation rather than, for example, by some administrative agency. The role of class action and derivative litigation in this broader societal setting is an important topic for research,$^{18}$ but is outside the scope of this paper. The following discussion assumes that private enforcement of the applicable substantive laws represents sound social policy, or at least a policy preferred by those charged with making and enforcing the laws.

15 FRCP 23.1.

Is Id.

17 Id.

18 See, for example, Del Chanc Ct R 23.1.

10 For one interesting study critical of the effect of derivative litigation, see Daniel $R$. Fischel and Michael Bradley, The Role of Liability Rules and the Derivative Suit in Corporate Law: A Theoretical and Empirical Analysis, 71 Cornell L Rev 261 (1986) (event study finding that instigation of derivative litigation did not positively affect share prices). For an argument that the private incentives to litigate in class and derivative cases may often be inadequate in terms of social benefits, see Coffee, 86 Colum $\mathrm{L}$ Rev at 677-98 (cited in note 4). 
B. The Role of the Entrepreneurial Attorney in Class Action and Shareholder's Derivative Suits

The role of the entrepreneurial attorney in class-and derivative litigation can best be understood in terms of the economic theory of agency costs. ${ }^{20}$ Accordingly, we first discuss agency cost theory in general and apply that theory to the analysis of standard litigation. We then contrast the nature of the agency problems in traditional litigation with the special agency problems that arise in class and derivative litigation.

1. The economic theory of agency and its application to standard litigation.

The attorney in litigation is, in theory and legal form, the agent of the client. ${ }^{21}$ As agent, the attorney is charged with the duty to advance the client's interests "zealously within the bounds of the law."22 Yet attorneys do not always fulfill this responsibility, because their interests are rarely perfectly aligned with those of the client. The client pays the bill; the lawyer does the work. Many of the regulatory structures applicable to lawyers are designed to ensure that lawyers act as faithful agents of clients and do not abuse the client's trust.

The lawyer's role as agent of the client can be analyzed from an economic perspective with modern tools of agency cost theory. Although this theory has roots far back in the history of economic thought, the modern analysis of agency costs stems from the work of Ronald Coase ${ }^{23}$ and, more recently, of Michael Jensen and William Meckling. ${ }^{24}$ Jensen and Meckling define the agency relation-

20 Professor Coffee appears to be the first scholar expressly to apply agency cost theory to class litigation. See Coffee, 62 Ind L J at 628-34 (cited in note 4); Coffee, 54 U Chi L Rev at 883-89 (cited in note 4). Our debt to Coffee should be obvious. However, we extend his analysis in several respects, including our discussion of bonding devices in the attorneyclient relationship, our elaboration of the incentive problems under various compensation regimes, and our analysis of the differences between traditional litigation settings and class and derivative suits. For an early, but insightful, discussion of agency problems in entrepreneurial litigation, see Dam, $4 \mathrm{~J}$ Legal Stud at 58-59 (cited in note 4).

${ }^{21}$ See Geoffrey P. Miller, Some Agency Problems in Settlement, 16 J Legal Stud 189 (1987).

22 American Bar Association, Model Code of Professional Responsibility (Model Code) Canon 7, reprinted in Thomas D. Morgan and Ronald D. Rotunda, Selected Standards on Professional Responsibility 1-69 (Foundation, 1989). See also note 30.

23 Ronald H. Coase, The Problem of Social Cost, 3 J L \& Econ 1 (1960). .

24 Michael C. Jensen and William H. Meckling, Theory of the Firm: Managerial Behavior, Agency Costs and Ownership Structure, 3 J Fin Econ 305 (1976). Although Jensen and Meckling restrict their agency cost theory to analysis of corporate financial structure, 
ship as "a contract under which one or more persons (the principal(s)) engage another person (the agent) to perform some service on their behalf which involves delegating some decision making authority to the agent." 25 In such cases, as Jensen and Meckling observe, the interests of the agent are likely to deviate from those of the principal. This deviation of interests may not serve either principal or agent ex ante, and both, accordingly, may expend resources to overcome it. Jensen and Meckling identify two principal means for reducing agency costs: monitoring by the principal and bonding by the agent. ${ }^{26}$ To these we might add a third, namely devices that align the incentives of the agent more closely with those of the principal.

a) Monitoring. The effectiveness of monitoring depends on the observability of the agent's performance. Monitoring costs will be slight when the agent's performance can be readily observed by the principal so that the principal can reliably and cheaply measure the marginal product of the agent's actions. ${ }^{27}$ Two strategies can be used singly or in combination to measure the agent's performance. First, the performance can be observed directly by a principal capable of judging the marginal product of the performance. Second, the marginal product can be determined by the outcome of the agent's actions to the extent that the actions uniquely determine the outcome. ${ }^{28}$ But often neither of these conditions holds: the principal cannot readily determine marginal product by observing the agent's actions (either because the actions themselves are not readily observable or because the principal cannot evaluate the marginal product of the actions observed), and the principal cannot reliably measure marginal product by outcome because the agent's actions merely contribute to, but do not determine, the observed outcome. In these situations monitoring will be relatively more expensive and less effective. The principal may have to rely on some proxy for the agent's performance that is relatively easy to observe but inexact. Observing such a

they recognize that the basic elements of the theory are applicable to a much broader range of economic transactions. Id at 309. See also Kenneth J. Arrow, The Economics of Agency, in John W. Pratt and Richard J. Zeckhauser, eds, Principals and Agents: The Structure of Business 37 (Harvard Business School Press, 1985).

${ }^{25}$ Jensen and Meckling, $3 \mathrm{~J}$ Fin Econ at 308 (cited in note 24).

28 Id.

${ }^{27}$ This assumes that the principal and agent have adopted appropriate contractual terms such that the agent's compensation is tied to marginal product.

${ }^{28}$ Arrow, The Economics of Agency, in Pratt and Zeckhauser, eds, Principals and Agents at 37 (cited in note 24). 
proxy, however, would be only partially effective at eliminating shirking or abuse of trust by the agent.

In the traditional lawsuit, monitoring the lawyer is likely to be costly and therefore incomplete. The client, as principal, cannot easily observe the lawyer's efforts because much of the lawyer's work is performed outside of the client's supervision. Even when the client can observe the lawyer's work-for example, by reviewing a draft of a brief or attending oral argument-the client typically lacks the expertise to determine whether the attorney is actually doing a good job on the client's behalf. And except in a few unusual situations in which results turn entirely on the lawyer's efforts-such as simple incorporations and other changes in legal status that are granted as a matter of course provided proper applications are filed-the client cannot accurately measure the lawyer's marginal product by outcome. Good lawyers lose cases and bad lawyers win them. Although the client has some ability to monitor the lawyer - the client can assess the attorney's reputation before hiring her, can examine work product, and can request second opinions from other attorneys-the attorney inevitably retains a relatively large area of discretion in which shirking or abuse is possible.

The legal regulatory system contains a variety of provisions designed to reduce monitoring costs and thereby enhance the client's ability to supervise her attorney. The most obvious examples are the rules on admission to and retention of membership in the bar itself. Because good standing in the bar carries with it assurances regarding the lawyer's propensity to act as a competent and faithful fiduciary, it provides a readily observable proxy for qualities that the client might otherwise find quite difficult to measure (such as whether the lawyer possesses an adequate knowledge of the law, or whether the lawyer has behaved scrupulously toward other clients in the past).$^{28}$ Of course, the standards for admission and retention of membership in the bar are quite inexact, are set relatively low, and do not sort between quality levels above the minimum floor. Good standing may not be a particularly informative proxy for competence or integrity. Nevertheless, it may have some value.

29 See Hayne E. Leland, Quacks, Lemons, and Licensing: A Theory of Minimum Quality Standards, $87 \mathrm{~J}$ Pol Econ 1328 (1979) (minimum quality standards can be economically efficient in markets with large information asymmetries between buyer and seller, but quality standards are likely to be too high if set by the affected industry or profession itself). 
Other rules that reduce agency costs by enhancing monitoring are found in the codes of attorney ethics. The lawyer is obligated to keep the client reasonably informed about the status of the matter $^{30}$ and to abide by the client's decisions on important matters such as whether to accept an offer of settlement. ${ }^{31}$ These rules are based on the theory that a client who is informed about the representation and given the power to make the key decisions will be a more effective monitor than one who is unaware of a matter or who is unable to affect its prosecution. Client monitoring is further enhanced by the rule that the client may discharge her attorney at any time. ${ }^{32}$

Finally, the costs of monitoring may be reduced by ethics rules prohibiting conduct that can reliably be identified as contrary to the interests of the client. The attorney is not permitted to charge a vexatious or unreasonable fee, ${ }^{33}$ divulge the confidences or secrets of the client, ${ }^{34}$ fail to exercise due diligence on the client's behalf, ${ }^{36}$ or commingle funds with client accounts. ${ }^{36}$ These types of behavior are considered so inherently harmful to the client's interest that they can be prohibited outright by the regulatory system, relieving the client of some of the responsibility for supervising the attorney. ${ }^{37}$

b) Bonding. Where monitoring costs are high, the optimal strategy may be for the agent to engage in some form of bonding to

\footnotetext{
so See Model Code EC 7-8, EC 9-2; American Bar Association, Model Rules of Professional Conduct (Model Rules) Rule 1.4, reprinted in Morgan and Rotunda, Selected Standards on Professional Responsibility at 82-177 (cited in note 22). Although there are substantive differences between the two provisions, the analysis of the attorney's obligation to keep the client informed and to abide by the client's decisions on basic matters is similar under both systems.

The Model Code and Model Rules are model statutes promulgated by the ABA for use by state bar regulatory authorities. The Model Code was adopted in 1969, and the Model Rules were adopted in 1983. See generally Charles W. Wolfson, Modern Legal Ethics 56-63 (West, 1985).

"1 See Model Code EC 7-7; EC 7-8; Model Rule 1.2. But see Model Code DR 7101(b)(1) (a lawyer may, "where permissible, exercise his professional judgment to waive or fail to assert a right or position of his client").

${ }^{32}$ See Model Code DR 2-110(B)(4); Model Rule 1.16, Comment [4].

ss Model Code DR 2-106(A); DR 2-106(B); Model Rule 1.5(a).

s4 See Model Code Canon 4; DR 4-101; Model Rule 1.6; Model Rule 1.9(b).

ss See Model Code DR 6-101(A)(3); EC 6-4; Model Rule 1.3.

${ }^{36}$ Model Code DR 9-102; Model Rule 1.15.

${ }^{37}$ Of course, attorney breaches of these ethical obligations are unlikely to result in sanctions unless the client discovers them. Thus, some monitoring by clients is required for these prohibitions to have their desired effect. But see Model Code DR 1-103(A) (lawyer possessing unprivileged knowledge of violation by another lawyer of disciplinary rules "shall" report such knowledge to authority empowered to investigate and act on such violations).
} 
assure the principal that the agent will carry out her duty to the principal faithfully even in the absence of effective monitoring. Such bonding can be by means of explicit contracts, as in the case of bond covenants, ${ }^{38}$ or by implicit structural features of the principal-agent relationship.

Bonding mechanisms can readily be identified in the case of legal services. First, lawyers enjoy an exclusive right to practice law. The license to practice carries with it the ability to earn income considerably in excess of what the attorney would be able to earn by other uses of her time, both because the attorney receives compensation for the relatively large opportunity and out-ofpocket costs of legal education, and because the attorney probably receives some monopoly rents flowing from the exclusion of nonattorneys from the practice of law. ${ }^{39}$ The attorney who engages in egregious abuse of the client's trust risks losing these extra profits as a result of suspension or disbarment. The attorney's interest in maintaining the right to practice thus operates as a bonding device to assure clients that the attorney will observe at least minimal fiduciary standards.

Second, lawyers invest in reputation. They do so, for instance, by scrupulously serving their clients over a long period of time, by engaging in extensive public service activities, and by hiring the best and the brightest law school graduates. If these costly activities are successful in establishing a reputation, the law firm will be able to charge higher rates-thus obtaining an economic return from its investment in reputation. At the same time, the firm that has built up a reputation has a strong interest in maintaining that reputation by continuing to observe high ethical and quality standards. ${ }^{40}$ Thus, reputation also acts as a bonding device-albeit an

ss See Clifford W. Smith, Jr. and Jerold B. Warner, On Financial Contracting: An Analysis of Bond Covenants, $7 \mathrm{~J}$ Fin Econ 117 (1979) (analyzing how bond covenants, i.e., contractual promises made by a corporation to the holders of its bonds, control agency costs).

${ }^{38}$ There are no reliable studies of the extent of such monopoly rents. Studies of other licensed professions, however, have claimed to demonstrate the existence of monopoly profits. See, for example, Keith B. Lefler, Physician Licensure: Competition and Monopoly in American Medicine, 21 J L \& Econ 165 (1978); Lawrence Shepard, Licensing Restrictions and the Cost of Dental Care, $21 \mathrm{~J} \mathrm{~L} \mathrm{\&} \mathrm{Econ} \mathrm{187,} 200$ (1978) (where regulatory authorities have constructed competitive barriers to practice, dentists have systematically raised fees by 12-15 percent).

10 The role served by reputation is enhanced by the fact that lawyers often obtain clients through referrals from other lawyers. 
imperfect one $e^{41}$ - that assures clients that agency costs will not be excessive. ${ }^{42}$

c) Incentives. A third approach to reducing agency costs, which may be conceptualized as a specialized form of bonding, is to design incentive structures that reduce the disparity of interest between principal and agent. ${ }^{43}$ The need for monitoring decreases as the interests of principal and agent coalesce. One obvious means for improving the alignment of interests between principal and agent is to pass some of the risk of the enterprise on to the agent. The optimal amount of risk sharing will depend on the parties' relative degrees of risk-aversion as well as other factors. ${ }^{44}$

Incentive structures in the attorney-client relationship act as partial, but quite incomplete, substitutes for client monitoring and attorney bonding. The standard hourly fee eliminates an incentive the lawyer might have under other fee arrangements to work insufficient hours on the case. Yet the hourly fee also permits opportunism by attorneys. They may incur excessive hours, pad the bill, ${ }^{45}$ or encourage clients to go to trial (and thus incur additional fees) when settlement would be in the clients' best interests. ${ }^{46}$

The contingent fee partially aligns the interests of lawyer and client by giving the lawyer an economic interest in the outcome of the case, resulting in the sharing of risk that may benefit both parties. ${ }^{47}$ Yet the contingent fee also gives the attorney an incentive to pay insufficient attention to cases where the marginal return to the attorney's time is low relative to other cases in the attorney's port-

"1 Reputations are inexact, suffer from time lag effects, and are subject to being "cashed in" by firms willing to sacrifice their reputations in exchange for increased shortterm profits.

42 See Janet Kiholm Smith and Steven R. Cox, The Pricing of Legal Services: A Contractual Solution to the Problem of Bilateral Opportunism, 14 J Legal Stud 167, 169 (1985) ("[c]redible signals of reputation may reduce product or service quality uncertainty for prospective clients").

13 See Milton Harris and Artur Raviv, Optimal Incentive Contracts with Imperfect Information, $20 \mathrm{~J}$ Econ Theory 231 (1979).

" See Steven Shavell, Risk Sharing and Incentives in the Principal and Agent Relationship, 10 Bell J Econ 55 (1979) (if agent is risk-averse, her optimal fee depends to some extent on the outcome, but never leaves the agent bearing all the risk).

${ }^{45}$ See, for example, Kirchoff v Flynn, 786 F2d 320, 324 (7th Cir 1986); Smith and Cox, $14 \mathrm{~J}$ Legal Stud at 167-68 (cited in note 42); Charles W. Wolfram, The Second Set of Players: Lawyers, Fee Shifting, and the Limits of Professional Discipline, $47 \mathrm{~L}$ \& Contemp Probs 293, 302 (Winter 1984).

16 See Miller, $16 \mathrm{~J}$ Legal Stud at 203 (cited in note 21).

47 See Kirchoff, 786 F2d at 325; Patricia Munch Danzon, Contingent Fees for Personal Injury Litigation, 14 Bell J Econ 213 (1983) (contingent fees found to be superior to hourly fees when the plaintiff is risk-averse and the attorney is risk-neutral); Murray L. Schwartz and Daniel J.B. Mitchell, An Economic Analysis of the Contingent Fee in Personal-Injury Litigation, 22 Stan L Rev 1125, 1152 (1970) (contingent fee does not perfectly align interests of client and attorney, but does reduce risk). 
folio, and to settle early for a lower amount than the attorney could obtain for the client by putting more time and effort into the case. ${ }^{48}$

The legal regulatory system also seeks to align the interests of attorney and client. The lawyer's basic ethical obligation under Canon 7 of the Model Code of Professional Responsibility is to be a "zealous" advocate of the client's interest (provided, of course, that the lawyer remains within the bounds of the law). ${ }^{49}$ The obligation of zeal in representing the client is, effectively, an obligation to act as if the client's interests were those of the attorney. One may, of course, question the efficacy of a mere hortatory principle, especially one stated as a "canon." However, we believe that cultural or institutional values do play a role in influencing behavior, at least at the margin. Lawyers who have been socialized into the ideals of a profession that values zealous service of the client's interests are more likely to act in accordance with such ideals than will individuals who have not been socialized in the same value structure.

The ethics rules contain several provisions designed to align interests of attorney and client that are backed with greater sanction than the ideal of Canon 7. Consider the rules generally prohibiting attorneys from representing clients with differing or conflicting interests. ${ }^{50}$ Similarly a lawyer is generally prohibited from representing a client if her own interests could impair the representation. ${ }^{51}$ The conflict-of-interest rules exclude from representation a class of attorneys especially likely to have interests that deviate substantially from the interests of their clients. Thus certain egregious misalignments of attorney-client interests are ruled out.

48 See, for example, Chesny v Marek, 720 F2d 474, 477 (7th Cir 1983), rev'd on other grounds, 473 US 1 (1985) (giving numerical example of an inappropriate settlement resulting from an economic conflict of interest); Kevin M. Clermont and John D. Currivan, Improving on the Contingent Fee, 63 Cornell L Rev 529, 536 (1978).

19 Model Code Canon 7. The ideal of zealous advocacy in the Model Code is substantially moderated in the Model Rules. See Model Rule 1.3 ("A lawyer shall act with reasonable diligence and promptness in representing a client."); id, Comment [1] ("A lawyer should act with ... zeal in advocacy upon the client's behalf [but] is not bound to press for every advantage that might be realized for a client.").

so See Model Code DR 5-105 (simultaneous conflicts); Model Rule 1.7 (same); Model Rule 1.9 (conflicts with former clients); Model Rule 1.10 (imputed disqualification of lawyers in firms).

${ }^{31}$ See Model Code DR 5-101; DR 5-102 (generally requiring withdrawal when the lawyer becomes a witness in litigation); DR 5-103 (disapproving attorney acquisition of an interest in litigation); DR 5-104 (limiting business relationships between attorneys and clients); Model Rule 1.8 (same). 
d) Residual loss. These three devices for controlling the misalignment of interests between principal and agent-monitoring, bonding, and incentives-are themselves costly. It would not be in the interest of either principal or agent to eliminate all potential for behavior by the agent that does not serve the principal's interests. Monitoring, bonding, and incentives will be utilized only up to the point where the marginal cost of overcoming the misalignment of interests between principal and agent equals the marginal cost of the misalignment itself. Jensen and Meckling observe, therefore, that there will always be a residual loss inherent in the agency relationship. ${ }^{52}$ The problem for the agency relationship is to design a structure for the relationship that minimizes total agency costs, which are equal to the sum of monitoring costs, bonding costs, incentive costs, and the residual loss.

2. Application of agency cost theory to class and derivative cases.

As applied to legal representation in general, the regulatory system seems to have designed a moderately successful structure, even though client monitoring and bonding remains costly and imperfect. Existing regulations fail their intended purposes, however, in the context of large-scale, small-claim litigation.

The existing regulatory system cannot effectively deal with agency costs that arise in class action and derivative litigation because plaintiffs in the class action and derivative context are often completely incapable of monitoring the attorney. ${ }^{53}$ In addition, standard bonding and incentive techniques are much less effective in class and derivative litigation.

a) Monitoring. Members of the plaintiff class in a large class action or shareholder's derivative suit often have claims so small that the litigation is a matter of relative unimportance to them. ${ }^{54}$ Even though the claims in the aggregate may be very large,

${ }_{62}$ Jensen and Meckling, $3 \mathrm{~J}$ Fin Econ at 308 (cited in note 24).

ss The client's inability to monitor the attorney in class and derivative litigation is wellunderstood. See, for example, Greenfield v Villager Industries, Inc., 483 F2d 824, 832 n 9 (3d Cir 1973); Cooper, Do the Merits Matter? at 83-86 (cited in note 3) ("[t]he client disappears in securities class actions as a result of the same collective action problems that led to the invention of class actions in the first place"); Dam, $4 \mathrm{~J}$ Legal Stud at 58-59 (cited in note 4); David Rosenberg, Class Actions for Mass Torts: Doing Individual Justice by Collective Means, 62 Ind L J 561, 582 n 86 (1987).

s4 Instructive in this regard is the response rate to notice of settlement in many class cases. Even though the notice of settlement usually informs members of the plaintiff class 
the small size of the individual claims creates enormous free-rider effects: no rational plaintiff would take on the role of litigation monitor because she would incur all the costs of doing so but would realize only her pro rata share of the benefits.

Indeed, even if plaintiffs wanted to monitor the litigation, they would experience severe difficulties in doing so because they are often entirely unaware that the litigation is pending until after a settlement has been reached. ${ }^{\mathrm{s}}$ Even where an individual class member is aware of pending litigation, it is far from clear that she could have much influence on the class attorney because the attorney must act for the benefit of the class as a whole and therefore is not obliged to follow the unilateral wishes of any individual class member when those wishes deviate from the attorney's sense of optimal litigation strategy. ${ }^{.6}$

These collective action and free-rider effects allow the plaintiffs' attorney in class and derivative cases to operate with nearly total freedom from traditional forms of client monitoring. Moreover, enhancing client monitoring by keeping clients informed and deferring to their wishes on strategy is infeasible. The costs of communicating with the dispersed plaintiff class are high to begin with. Even if the class members are informed about a particular litigation problem, organizing a procedure for making a decision would be difficult and costly, especially if, as is usually the case in litigation, the choice involved is not a simple bipolar decision in which a simple majority vote procedure would suffice. And even if a decision procedure for the class were devised and implemented, the outcome of the class's deliberations would not necessarily be optimal, given that class members with small stakes have little incentive to research the problem or to deliberate at any length.

b) Bonding. The inefficacy of client monitoring in class and derivative suits is mirrored by a reduced role for bonding as a device for overcoming agency costs in these contexts. Plaintiffs' attorneys are, to be sure, members of the bar who would lose their livelihoods if they were excluded from the right to practice law. However, in the absence of a client actively interested in the litigation, plaintiffs' attorneys have less cause to fear bar discipline for

\footnotetext{
that they have won money and need merely fill out a brief form to obtain it, many plaintiffs never claim their share of the fund. See, for example, Zimmer Paper Products, Inc. v Berger \& Montague, 758 F2d 86 (3d Cir 1985) (12 percent response rate); Herbert B. Newberg, Class Actions CS7-50 (McGraw-Hill, 1977 \& Supp 1984).

${ }^{s s}$ See notes $82-100$ and accompanying text.

${ }^{B 6}$ See notes $119-23$ and accompanying text.
} 
misconduct simply because no one is likely to refer them to the disciplinary authorities if they misbehave. While a referral could conceivably be made by a judge or defense attorney, these parties do not have a direct personal stake in sanctioning a plaintiffs' attorney who has abused the trust of his or her clients. Indeed, the interests of defense attorneys' clients are often served if the plaintiffs' attorney breaches a duty to her clients by, for example, settling for a relatively low sum early in the litigation in order to obtain a high fee per hour invested in the case. ${ }^{67}$ Thus, despite the putative obligation to report violations of the disciplinary rules, ${ }^{58}$ defense attorneys are unlikely to be reliable sources of information regarding plaintiffs' attorneys' disciplinary violations.

The lack of client monitoring in the class and derivative context also reduces the efficacy of reputational bonding, which, as noted above, lowers agency costs in traditional litigation settings. Because clients do not pick their attorneys in class and derivative suits, plaintiffs' attorneys have little incentive to invest in reputations for probity and reliability in order to attract clients. The attorneys themselves are responsible for initiating the litigation and do not rely on clients to come to them with cases. Plaintiffs' attorneys do have an incentive to build a reputation, but the parties they wish to impress are not the clients. Rather, they have an interest in being known among other plaintiffs' attorneys as persons of ability, drive, perseverence, and long-range commitment to engaging in class and derivative litigation. Such a reputation can serve them in good stead in the competition among plaintiff's' attorneys for rights to pursue particular lawsuits. ${ }^{59}$ Plaintiffs' attorneys benefit from developing reputations among the defense bar for toughness and perseverence, but also for willingness to "deal" by negotiating settlements that minimize the costs to defense counsels' clients. ${ }^{60}$ Thus, while some elements of plaintiffs' attor-

${ }^{87}$ Similarly, trial judges interested in clearing their dockets and keeping up with arduous trial schedules are unlikely to object to premature settlements. See notes 130-34 and accompanying text.

${ }^{88}$ See Model Code DR 1-103(A) (mandatory duty to disclose that another attorney has violated a disciplinary rule if that information is unprivileged); Model Rule 8.3 ("A lawyer having knowledge that another lawyer has committed a violation of the rules of professional conduct that raises a substantial question as to that lawyer's honesty, trustworthiness or fitness as a lawyer in other respects, shall inform the appropriate professional authority.").

so See Coffee, 86 Colum L Rev at 713 (cited in note 4); Coffee, $42 \mathrm{Md} \mathrm{L} \mathrm{Rev} \mathrm{at} \mathrm{248-61}$ (cited in note 4).

0 See Herbert B. Newberg, 3 Class Actions $\$ 5515 . b$ at 456 (McGraw-Hill, 1977) (defendant should consider the "reputation and experience of counsel for the class representative" in deciding whether to propose a settlement). 
neys' desired reputations-toughness, ability, and perseverence, for example-may well correlate with service to clients, in other respects the reputations desired by plaintiffs' attorneys are not coextensive with client.interests-for example, a reputation for a willingness to "deal" with defense attorneys, even at the expense of their own clients' best interests.

c) Incentives. Finally, consider incentive effects in class and derivative litigation. The lack of monitoring and the relative inefficacy of bonding in these settings would not be especially problematic if the interests of plaintiffs' counsel were closely aligned with those of their clients. Unfortunately, there is a substantial deviation of interests between attorney and client. The nature of the conflict varies depending on the type of litigation involved and the procedure used in the jurisdiction for determining the attorney's fee. But at least under the existing regulatory system, the conflict remains significant in all cases. ${ }^{61}$

In "common fund" cases, where the plaintiffs' attorney generates a fund for the benefit of the class, the majority of American courts award fees out of the fund based on the lodestar calculation. ${ }^{62}$ Under this approach, the hours reasonably expended by the lawyer are multiplied by the lawyer's reasonable hourly fee to cal-. culate a lodestar. The lodestar is then adjusted by a multiplier to account for a variety of factors including, most significantly, the risk of the litigation. Attorneys in these cases thus have an incentive to run up excessive hours, delay the litigation unnecessarily, or even to exaggerate the number of hours expended in order to obtain a larger fee. ${ }^{63}$ Plaintiffs' attorneys may also wish to settle for a relatively low sum on the eve of trial, knowing that in so doing they obtain most of the benefits they can expect from the litigation while eliminating their downside risk. ${ }^{64}$ These abuses are checked,

a1 These conflicts could be substantially reduced or eliminated by an auction of the claim. See notes $326-29$ and accompanying text.

${ }^{62}$ The seminal case on the lodestar approach is Lindy Bros. Builders v American Radiator \& Standard Sanitary Corp., 487 F2d 161 (3d Cir 1973). See Robert T. Mowrey, Attorney Fees in Securities Class Action and Derivative Suits, 3 J Corp L 267, 334-48 (1978); Alexander Hammond, Stringent New Standards for Awards of Attorney's Fees, 32 Bus Law 523, 525-27 (1977).

${ }^{\text {es }}$ For a case in which the court suspected the plaintiffs' attorneys of excessive work or falsification of hours, see In re Fine Paper Antitrust Litigation, 98 FRD 48, 172, 177-78 (E D Pa 1983), modified on other grounds, 751 F2d 562 (3d Cir 1984). Some courts are beginning to question the lodestar method because of these dangers. See, for example, In re Oracle Securities Litigation, 131 FRD 688, 689 (N D Cal 1990); In re Chrysler Motors Corp. Overnight Evaluation Program Litigation, 736 F Supp 1007, 1015 (E D Mo 1990).

64 See Coffee, 86 Colum L Rev at 717-18 (cited in note 4). 
to a degree, by the required judicial scrutiny of fee awards and settlements in class and derivative litigation. ${ }^{65}$ Nevertheless, agency costs in cases where fees are calculated using the lodestar method are no doubt substantial.

Further, plaintiffs' attorneys may sometimes substantially reduce their risk by reaching an understanding with defense counsel early on about the contours of the eventual settlement. Then they can expend a mutually acceptable number of additional hours on the case, charging them against the settlement fund under the lodestar calculation. The social disutility of this procedure is obvious; it represents an essentially meaningless exercise that ties up the resources of plaintiffs' counsel, defense counsel, and others such as witnesses who must submit to depositions that all parties understand will never be used in court. The principal losers are members of the plaintiff class who must pay over part of their recovery to counsel for work that serves no purpose other than to justify an enhanced attorney's fee.

The other method of calculating attorneys' fees in common fund cases, which has become more popular recently, ${ }^{66}$ is the "percentage" method, in which fees are awarded based on some fixed percentage of the fund. There are obvious incentive problems with this arrangement as well. First, plaintiffs' attorneys will earn windfall profits, at the expense of the class members, in cases presenting large damages and low proof costs. More generally, it would appear that the percentage method effectively guarantees that

os See notes 124-83 and accompanying text. For an optimistic assessment of the value of judicial scrutiny, see In the Matter of Superior Beverage/Glass Container Consolidiated Pretrial, 1990 US Dist LEXIS $14756,{ }^{*} 13$ (N D IIl) (judge observed that fee padding under the lodestar regime was unusual, and to the extent it occurs, "careful judges and their staffs should be able to spot the worst, if not all, abuses").

s See, for example, In re Oracle Securities Litigation, 131 FRD 688, 689 (N D Cal 1990) (lodestar approach is "now thoroughly discredited by experience"); In re Chrysler Motors Corporation Overnight Evaluation Program Litigation, 736 F Supp 1007, 1009 (E D Mo 1990); In re Union Carbide Corporation Consumer Products Business Securities Litigation, 724 F Supp 160, 170 (S D NY 1989). But see, for example, Superior Beverage/Glass Container Consolidated Pretrial, 1990 US Dist LEXIS 14756 at*8 (rejecting as "overly simplified and shortsighted" any rule for awarding fees on a straight percentage basis without regard to hours billed).

The current rise of the percentage method represents something of a reprise, since prior to the ascendency of the lodestar method in the 1970 s the percentage method was the prevailing method for calculating fees in common fund cases. See, for example, John P. Dawson, Lawyers and Involuntary Clients in Public Interest Litigation, 88 Harv L Rev 849, 876 (1975); Douglas G. Cole, Counsel Fees in Stockholders' Derivative and Class Actions-Hornstein Revisited, 6 U Richmond L Rev 259, 283-85 (1972); George D. Hornstein, Legal Therapeutics: The "Salvage" Factor in Counsel Fee Awards, 69 Harv L Rev 658, 66465 (1956). 
plaintiffs' attorneys will be systematically. compensated at a rate higher than the rate they would demand in an efficiently functioning competitive market. To illustrate this point, consider the thought process of a plaintiff's' attorney in deciding whether to bring a given cause of action. The attorney operating in a percentage-of-the-recovery system will never bring an action when the expected opportunity costs to the attorney of bringing the suit (as measured by the value the attorney places on his or her time) exceed the expected award of attorneys' fees (equal to the present value of the expected recovery for the class multiplied by the fee percentage used in the jurisdiction and further discounted by the attorney's estimate of the probability of success in the litigation) ${ }^{67}$ The plaintiffs' attorney faces a distribution of cases in which one tail-representing cases where the expected payoff to the attorney falls short of the attorney's expected costs-is cut off. ${ }^{68}$ On the other hand, the attorney can be expected to bring all cases where the expected payoff equals or exceeds the attorney's expected costs.

Among the cases that are brought will be a wide range of cases in which the expected payoff exceeds the attorney's expected costs. Because the applicable fee percentage is not adjusted downward in such cases-as it would be in an efficiently functioning market for contingency fee representation ${ }^{69}$ - these excess profits are not dissipated by competition. In theory, a court could reduce a percentage award downward in such cases, but such judicial reductions would not necessarily be reliable, and would add an additional level of complexity and cost to fee calculations. Thus; plaintiffs' attorneys can be expected to reap systematic excess profits, of which windfall cases are only the most noteworthy examples, under a percentage method..$^{70}$ These excess profits are earned at the expense of the plaintiff class.

87 We use the concept of opportunity costs in the technical economic sense as" including a reasonable profit.

as These cases, moreover, will never be brought even though members of the plaintiff class have valid legal claims that would receive vindication if a higher percentage fee were available. The auction approach we advocate in Part $\mathrm{V}$ would overcome this problem because the bidders could purchase the claims, or acquire the litigation rights, for whatever they are worth.

Whether the market for contingency fee representation is in fact competitive is another story. For an argument that contingent fees are generally not set competitively, see Lester Brickman, Contingent Fees Without Contingencies: Hamlet Without the Prince of Denmark?, 37 UCLA L Rev 29, (1989).

70 See In re Oracle Securities Litigation, 131 FRD 688, 696 (N D Cal 1990) (noting that lawyers would receive "more in fees than they would have bargained for" if they were paid 
The second incentive problem in percentage-of-the-recovery cases is settlement. Attorneys compensated on a percentage method have an incentive to settle early for an amount lower than what might be obtained by further efforts. ${ }^{71}$ The attorney who puts in relatively few hours to obtain an early settlement is likely to earn a much greater compensation per hour of effort than an attorney who expends greater efforts and litigates a case to the point where the plaintiffs' recovery is maximized. ${ }^{72}$ Again the plaintiff class loses.

Consider now common benefit and fee-shifting cases. Common benefit cases are typically shareholder's derivative suits in which the plaintiffs' attorney does not generate a fund, but rather causes the defendant to do something that confers a nonpecuniary benefit on the corporation. ${ }^{73}$ Fee-shifting cases are brought under a statute providing that prevailing plaintiffs in certain types of litigation may obtain reimbursement for their reasonable attorneys' fees from the defendant. ${ }^{74}$ In common benefit and fee-shifting cases the attorneys' fee comes from the defendant rather than from the class recovery. ${ }^{25}$ Unlike common fund cases, therefore, there is a counter-party in common benefit and fee-shifting cases with an incentive to bargain over the fee in order to keep it within reasonable limits.

This feature, however, does not effectively obviate the attorney-client conflict. Defendants in common benefit and fee-shifting cases typically wish to minimize the sum of three costs: the costs of the relief on the merits, the costs of their own attorney's fees, and the costs of the plaintiffs' attorney's fees. Defendants are typically indifferent about how the total cost of litigation is distributed among these elements. Plaintiffs' attorneys, on the other hand,

at a rate under the percentage-of-recovery method that is higher than what they would have demanded in a competitive market).

${ }^{71}$ See, for example, Chesny v Marek, 720 F2d 474, 477 (7th Cir 1983); Saylor v Lindsley, 456 F2d 896, 900-01 (2d Cir 1972); Dam, $4 \mathrm{~J}$ Legal Stud at 56-58 (cited in note 4).

${ }^{72}$ See Miller, $16 \mathrm{~J}$ Legal Stud at 189 (cited in note 21) (emphasizing the analysis of the settlement figure for the claim as a whole, including the attorneys' share and the client's share).

${ }^{73}$ See Mills v Electric Auto-Lite Co., 396 US 375, $391-92$ (1970).

7" See Thomas D. Rowe, Jr., The Legal Theory of Attorney Fee Shifting: A Critical Overview, 1982 Duke L J 651.

${ }^{73}$ The corporation typically pays the fee in successful derivative litigation. This practice can be reconciled with the general American Rule on fees, under which each client pays his or her own attorney, see Alyeska Pipeline Service Co. v Wilderness Society, 421 US 240, 247 (1975), on the theory that victory in the litigation establishes that the plaintiffs' attorney was actually representing the corporation after all, and thus it is appropriate to require the corporation as "client" to pay the fee. 
have an interest in increasing their own fees, even at the expense of a reduction in the relief afforded to the putative client. Thus the conditions are present for a bargain under which the plaintiffs' attorneys agree to a lower overall settlement on the merits of the litigation in exchange for a higher fee. ${ }^{76}$

A related problem occurs when the defendant offers a relatively generous settlement on the merits on condition that the plaintiffs' attorney agrees to waive any fee request (or to accept a low fee). ${ }^{77}$ This conflict has led some courts and commentators to call for a mandatory rule separating the fee negotiation from the settlement on the merits in fee-shifting cases. ${ }^{78}$ Whether such a rule could be effectively enforced is open to question, however. ${ }^{79}$ Moreover, separating the fee negotiation from the merits determination raises the possibility that plaintiffs' attorneys who believe that a favorable settlement will eventually be reached will string out litigation well past the point where settlement first becomes possible in order to justify a higher fee request. Splitting the fee and merits negotiations is no panacea for the agency problems in the common benefit and fee-shifting contexts.

The regulatory system incorporates a number of special features designed to cope with the pervasive agency problems in class

${ }^{76}$ See, for example, Posner, Economic Analysis of Law at 537 (cited in note 8); Andrew Rosenfield, An Empirical Test of Class-Action Settlement, 5 J Legal Stud 113, 117 (1976) (empirical study suggesting that attorneys who settled class actions rather than taking them to judgment received an average fee premium of $\$ 104,000)$; Wolfram, $47 \mathrm{~L}$ \& Contemp Probs at 299-302 (cited in note 45 ).

${ }^{77}$ See Wolfram, $47 \mathrm{~L} \&$ Contemp Probs at 300-01 (cited in note 45).

${ }^{78}$ See, for example, Prandini v National Tea Co., 557 F2d 1015, 1021 (3d Cir 1977); Comment, Settlement Offers Conditioned Upon Waiver of Attorneys' Fees: Policy, Legal, and Ethical Considerations, 131 U Pa L Rev 793 (1983); Deborah L. Rhode, Class Conflicts in Class Actions, 34 Stan L Rev 1183, 1251 (1982); Wolfram, 47 L \& Contemp Probs at 299302 (cited in note 45). But see Evans v Jeff D., 475 US 717, 738 n 30 (1986) (upholding permissibility, under some circumstances, of simultaneous negotiation of fees and merits in civil rights litigation). Compare Miller, $16 \mathrm{~J}$ Legal Stud at 206-09 (cited in note 21) (effects of simultaneous fee and merits settlement negotiations are ambiguous).

${ }_{79}$ Presumably a rule against simultaneous negotiation of fees and merits would be effective against settlement offers on the merits conditioned on the plaintiffs' attorney waiving or reducing her request for fees, given that the plaintiffs' attorney could be expected to bring such offers to the attention of the court. However, generous fee offers coupled with reduced merits relief would be more difficult to police: the plaintiffs' attorney and the defendant could agree privately on such a settlement, with the defendant performing its part of the bargain by settling (or not objecting to) the fee request after the merits relief is presented to the court. Obviously in such cases the defendant might renege on the agreement and object to the fee request. But if the parties are repeat players, such behavior might well redound to the defendant's long-term detriment by precluding such deals in the future. See Arthur R. Miller, Attorneys' Fees in Class Actions 222 (Federal Judicial Center, 1980); Wolfram, 47 L \& Contemp Probs at 312 (cited in note 45). 
action and derivative suits. The next section discusses one way in which the system has adjusted for these problems: by allocating the authority to make decisions regarding the litigation to someone other than plaintiffs' attorney.

\section{Regulations Allocating Litigation Authority}

Class action and derivative suits present obvious problems for control of litigation on the plaintiffs' side. Four situations are of special interest: (1) notice and opt-out rights in class action cases; (2) rights by corporate managers to control derivative litigation; (3) conflicts between representative plaintiffs and plaintiffs' attorneys; and (4) judicial scrutiny of settlements and fee requests. For each category, we discuss the existing rules, critique those rules, and recommend changes that would better align the interests of attorney and client.

\section{A. Notice and Opt-Out Rights in Class Actions}

As we have seen, the putative clients in class action and derivative litigation are unable to monitor the activities of their attorneys or to make any of the key litigation decisions. ${ }^{80}$ In place of client control, Federal Rule 23(c)(2) requires that in (b)(3) class actions the members of the class must receive "the best notice practicable under the circumstances, including individual rotice to all members who can be identified through reasonable effort." The notice must inform the class members that they have the right to opt out of the class, and that if they do not opt out they will be bound by the judgment. ${ }^{82}$ The Supreme Court held in Eisen v Carlisle \& Jacquelin that no matter how large the class, or how small the average claim, individualized notice is required for all class plaintiffs who can be identified with reasonable effort. ${ }^{83}$

There is little to recommend the Eisen rule from the standpoint of economic analysis. The pecuniary costs of notice in large class actions can run well over half a million dollars. ${ }^{84}$ In addition,

so See notes 54-56 and accompanying text.

s1 FRCP 23(c)(2).

${ }^{82}$ Id. Prior to its revision in 1966, the rule had provided that class members must opt in to the action or be excluded.

s 417 US 156, 173-77 (1974). See Oppenheimer Fund, Inc. v Sanders, 437 US 340 (1978) (representative plaintiff, and not defendant, should generally bear cost of notice); Phillips Petroleum Co. $v$ Shutts, 472 US 797 (1985) (notice required by due process).

st In Eisen itself, the Court's ruling would have required that individualized notice be mailed to approximately $2,250,000$ individuals at a cost of $\$ 225,000$. Eisen, 417 US at 16667. These were 1974 costs, however, when a first-class stamp was only six cents. Id at 167 . 
the costs of identifying absent class members and preparing the notice, as well as the opportunity costs to class members of interpreting the notice, can be substantial. These costs would be justifiable if they were outweighed by compensating benefits that might exist in a case with substantial individual claims. In the large-scale, small-claim class action, however, the benefits of notice appear minimal at best. It is doubtful whether notice has any social utility other than that of informing the class members of the claim. Most plaintiffs are unlikely to place any significant value on such information.

Upon receiving and reading notice of the suit, the typical plaintiff in a large-scale, small-stakes class action has a choice between two courses of action. She can do nothing, in which case she will receive a check in the mail if the suit is successful and will incur no costs if the suit fails. Or she can go to the trouble of opting out of the action, in which case she will receive nothing whether or not the suit is successful. ${ }^{85}$ Such a decision is not hard to make. Nearly 'everyone who understands the nature of this choice will elect to do nothing and thereby remain part of the class action. ${ }^{86}$ Accordingly, notice has little realistic value to class members in large-scale, small-stakes class actions.

We submit that in such cases the members of the plaintiff class would ordinarily be far better off dispensing with notice. Moreover, looking only at cases that are filed understates the dis-.

The costs of similar notice today would be considerably higher. See Mountain States Telephone and Telegraph Co. $v$ District Court, 12 Class Action Rep 305 (D Colo 1989) (notice to more than one million potential class members would cost over $\$ 500,000$ if mailed individually; court required notice to be inserted in defendant's billing envelopes at cost of approximately $\$ 300,000$ ). See also P.D.Q. Inc., of Miami v Nissan Motor Corp. in U.S.A., 61 FRD 372, 377 (S D Fla 1973), aff'd as In re Nissan Antitrust Litigation, 577 F2d 910 (5th Cir 1978) (estimated notice costs of $\$ 300,000$ ).

ss Of course, a class member could opt out and bring her own suit, but given the small nature of most class claims, this option is completely infeasible for the average class plaintiff. See Note, Developments in the Law-Class Actions, 89 Harv L Rev 1318, 1558 (1976).

${ }^{86}$ Statistics on opt-outs tend to substantiate this inference. See, for example, Steiner $v$ Fruehauf Corp., 121 FRD 304, 306 (E D Mich 1988), affd as Priddy $v$ Edelman, 883 F2d 438 (6th Cir 1989) (out of "thousands" of notices mailed to class plaintiffs, only 15 opted out); Fisher Brothers, Inc. v Mueller Brass Co., 630 F Supp 493, 498 (E D Pa 1985) (out of 37,000 plaintiffs to whom notices were mailed notice only 46 opted out); In re Cuisinart Food Processor Antitrust Litigation, 38 Fed Rules Serv 2d 446, 454 (D Conn 1983) (out of 1.5 million putative class members, only 89 opted out specifically in order to avoid the res judicata effect of the judgment; 825 opted out for other reasons). The relatively high opt-out rate observed in Phillips Petroleum, 472 US at 801 (3,400 plaintiffs opted out of a class of 33,000 royalty holders of oil and gas leases) was probably due to the existence of a discrete group of large claim holders in the plaintiff class who might benefit from individualized litigation. 
advantages of notice to members of the class that it is ostensibly designed to help. The predictable effect of Eisen is to prevent many lawsuits from being filed in the first place because of the added costs of notice. ${ }^{87}$ Potential class plaintiffs in such actions would unambiguously prefer to dispense with notice because doing so is the only feasible means for obtaining any recovery at all.

The Court in Eisen need not have reached the result it did. The plain language of Rule 23(c)(2) does require individualized notice to all class members who can be identified with reasonable effort. This seems fairly compelling at first blush. Yet the Supreme Court has not insisted on rigid adherence to plain language when the result would be absurd. ${ }^{88}$ Moreover, Rule 23(c)(2) itself implies that cost-benefit analysis should not be avoided altogether in the administration of the notice requirement. Under the federal rules, notice need only be sent to those class members who can be identified with "reasonable effort." The reasonable effort requirement must refer to some type of pragmatic calculus as to when the marginal costs of identifying further class members exceed the marginal benefits of doing so. It would be anomalous indeed if the drafters of the rule intended a cost-benefit analysis with respect to the identification of class members, but insisted on rigid and even self-defeating adherence to a notice requirement when it came to actually mailing out notice to class members so identified. In short, the Court in Eisen had the interpretive flexibility to read Rule $23(c)(2)$ in a practical and sensible way; regrettably, it failed to do so.

There are, to be sure, constitutional issues underlying the notice requirement. Due process generally requires that persons subject to litigation receive notice "reasonably calculated, under all the circumstances, to apprise interested parties of the pendency of the action and afford them an opportunity to present their objections." ${ }^{39}$ Dispensing with notice altogether in the class action context, even with respect to class members who can be identified relatively cheaply, would no doubt raise a serious constitutional

${ }^{87}$ See Report and Recommendations of the Special Committee on Class Action Improvements, 110 FRD 195, 208 (1986).

${ }^{88}$ See, for example, Public Citizen v United States Dept. of Justice, 491 US 440, 109 S Ct 2558, 2566-67 (1989); United Steelworkers of America v Weber, 443 US 193, 201-02 (1979); Philbrook v Glodgett, 421 US 707, 713-14 (1975).

${ }^{80}$ Mullane $v$ Central Hanover Bank \& Trust Co., 339 US 306, 314 (1950) (invalidating notice by publication to known beneficiaries of a common trust fund). See also Tulsa Professional Collection Services, Inc. v Pope, 485 US 478 (1988); Mennonite Board of Missions v Adams, 462 US 791 (1983). 
question. In Phillips Petroleum Co. $v$ Shutts, the Court expressly stated that notice-by which it apparently meant notice by mail-is constitutionally required in large-scale, small-claim class actions. ${ }^{90}$ But, the result in Shutts appears questionable at best. The Supreme Court has made quite clear that in the notice-of-litigation context, as in other due process clause analysis, the relevant analysis involves a balancing of costs and benefits. ${ }^{91}$ Cases in which the Court has required actual notice have typically involved two factors not present in large-scale, small-claim class actions. First, the property rights at issue have typically been substantial in size or importance to the party claiming the protections of the due process clause. ${ }^{92}$ Second, Supreme Court cases prior to Shutts typically involved situations in which a party stood to forfeit the property right if he did not receive notice of the proposed state action. ${ }^{93}$ It is not surprising, therefore, that in these cases the Court held that mail service was "an inexpensive and efficient mechanism that is reasonably calculated to provide actual notice." ${ }^{\text {9 }}$

In the large-scale, small-claim class action context, by way of contrast, the claims of the individual class members are very small. Eisen itself is typical; the named plaintiff in that case asserted damages of only $\$ 70 .^{95}$ Because plaintiffs in these cases are typically unaware that they even have a claim against the defendant, there is virtually no possibility that loss of the claim will cause damages to the plaintiff that exceed the value of the claim itself. The plaintiff's interest in receiving individualized notice is accord-

so 472 US 797, 812 (1985) ("[t]he plaintiff must receive notice plus an opportunity to be heard and participate in the litigation, whether in person or through counsel"). Shutts was a class action on behalf of approximately 33,000 plaintiffs with average claims of $\$ 100$. Id at 801 .

o1 See especially Pope, 485 US at 489-90 (when assessing the propriety of actual notice "consideration should be given to the practicalities of the situation" and to "the effect that requiring actual notice may have on important state interests"; reliance on publication notice alone is permissible if actual notice is unduly "burdensome or impracticable.").

${ }^{82}$ See, for example, Matter of Estate of Pope, 733 P2d 396, 397 (Okla 1987), rev'd as Pope, 485 US 478 (debt owed by decedent to medical center for hospital expenses in excess of $\$ 14,000$ ); Mennonite Board, 462 US at 794 (real property sold at tax sale for $\$ 1,167$ ).

${ }^{\circ}$ See, for example, Pope, 485 US at 481 (permanent cutoff of creditor's claim against assets of decedent's estate); Mennonite Board, 462 US at 793-94 (permanent loss of lien against real property); Greene $v$ Lindsey, 456 US 444, 446-47 (1982) (permanent loss of right to challenge eviction proceedings).

or Pope, 485 US at 490.

os Eisen, 417 US at 161. Cases involving large numbers of small claims are legion. For a recent example, see In re Anchor Securities Litigation, Fed Secur L Rptr (CCH) I 95,481 at 97,511 (E D NY and S D NY 1990) (settlement of $\$ 2.3$ million had to be divided, after deducting attorneys' fees award, among 17,595,000 shares). 
ingly considerably smaller in this context than in other situations. Further, while class action plaintiffs who are not provided with notice and who therefore do not have the opportunity to opt out may lose the theoretical right not to be bound by the res judicata effect of any eventual judgment, they also benefit substantially by gaining the right to participate in the funds received by the plaintiff class in any settlement or judgment. In the class action context, the right forfeited by becoming party to the proceedings is a matter of only slight importance at best. The analysis suggests that due process should not require individualized notice of small claimants prior to judgment or settlement in this specialized class action context. ${ }^{96}$

The continued viability of the large-scale class action after $E i$ sen is largely due to the fact that the notice requirement is routinely circumvented. Plaintiffs' counsel can avoid notice costs by classifying the litigation as a (b)(2) class action ${ }^{97}$ - where the party opposing the class has acted or refused to act on grounds generally applicable to the class, making injunctive or declaratory relief appropriate with respect to the class as a whole-for which advance notice of class certification is not usually required. ${ }^{98}$ And class action certification is typically put off until the last possible minute, often until the eve of trial ${ }^{99}$ or until the parties reach a settlement on the merits. ${ }^{100}$

Delaying certification benefits both the defendant and the plaintiffs' attorney, and thus presents great appeal to the parties who actually control the litigation. The plaintiffs' attorney benefits by not having to pay the high up-front costs of notice, and by not expending these costs subject to a risk of nonsuccess in the litiga-

${ }^{26}$ See Note, Civil Procedure-Class Actions-Amending Rule 23 in Response to Eisen v. Carlisle \& Jacquelin, 53 NC L Rev 409, 416-17 (1974).

${ }_{97}$ See note 10 and accompanying text. For cases recategorizing (b)(3) actions, see, for example, Stoetzner v US Steel Corp., 897 F2d 115, 119 (3d Cir 1990); Wetzel v Liberty Mutual Insurance Co., 508 F2d 239, 253 (3d Cir 1975).

${ }^{98}$ Notice is not required for (b)(2) class actions, but may be ordered by the judge as a matter of discretion. See Mark C. Weber, Preclusion and Procedural Due Process in Rule 23(b)(2) Class Actions, 21 Mich J Ref 347, 388 (1988). However, judges rarely require notice in (b)(2) cases. See Bryant G. Garth, Conflict and Dissent in Class Actions: A Suggested Perspective, $77 \mathrm{Nw}$ U L Rev 492, 514 (1982).

See, for example, Stoetzner, 897 F2d at 119.

${ }^{100}$ See, for example, In re Bendectin Products Liability Litigation, 749 F2d 300, 302 (6th Cir 1984); Malchman v Davis, 706 F2d 426, 429-30 (2d Cir 1983); Weinberger v Kendrick, 698 F2d 61, 73 (2d Cir 1982); County of Suffolk v Long Island Lighting Co., 710 F Supp 1422, 1424-25 (E D NY 1989), aff'd, 907 F2d 1295 (2d Cir 1990); Note, 89 Harv L Rev at 1559 (cited in note 85) ("class interests may be advanced by delaying notice until a settlement is imminent and the defendant may be willing to pay the costs [of notice]"). 
tion. ${ }^{101}$ Defendants benefit from putting off class action certification for a number of reasons.

First, defendants are likely to strike a more favorable settlement in advance of certification than afterwards. The reason is that the plaintiffs' attorneys are presumably likely to settle for less in advance of certification because doing so reduces their costs; these savings will be shared with the defendants.

Second, defendants may want to hedge their bets during the early phases of the litigation when they lack information about the strength or weakness of the plaintiffs' case and of opposing counsel. Defendants would prefer class certification of a case in which the plaintiffs' attorney is either incompetent or willing to settle out at a low figure. Defendants in such cases expect to pay only relatively minor damages. Accordingly, they have an interest in allowing the action to proceed on a class basis because certification offers res judicata protection against further litigation on the claim. On the other hand, defendants would prefer to avoid class certification in cases where the plaintiffs' attorney is competent, vigorous, and unwilling to settle on terms favorable to the defendant. As the litigation progresses, defendants obtain a better sense of the plaintiffs' attorney's competence and settlement strategy, and thus are able to make a more informed estimate of the costs and benefits of opposing the plaintiff's motion for class certification.

Third, defendants may want to put off certification in order to preserve the option of buying off the named plaintiff (or, more realistically, attorney) with a favorable settlement. ${ }^{102}$ These benefits to defendants of delaying the class certification decision often outweigh the advantages of forcing an early decision on certification that could either strike out the class allegations or force the plaintiffs' attorney to pay the costs of notification.

Delay of class certification until a settlement is reached on the merits remedies much of the harm inflicted by Eisen. Ordinarily in

\footnotetext{
201 In many states, the plaintiffs' attorney is formally required to insist on repayment of class certification costs by the named class representative, but in practice the costs are virtually always paid by the attorney alone. See notes 252-56 and accompanying text.

${ }^{202}$ See Raymond A. Fylstra, Settlement of Class Action Cases Prior to Class Certification, 69 Ill Bar J 24 (1980) (suggesting that in some cases the plaintiffs' attorney makes class allegations in the complaint in order to "enhance his personal bargaining leverage intending to blackmail the defendant"); Donald G. Kempf and Roger L. Taylor, Settling Class Actions, 13 Litigation 26, 28 (1986); Note, 89 Harv L Rev at 1540 (cited in note 85) (representative plaintiff can increase leverage by filing a class suit and then dropping the class allegations when her personal objectives have been met).
} 
class suits a mailing would be required for identifiable class members in order to allow them to state their claims of damages. A single mailing of checks is often not feasible because the amount of damages may vary across class members depending, for example, on how many shares of stock they purchased and what the market price was at the time of their transactions. Thus, because two mailings are often required in any event, sending notice together with a description of the proposed settlement and a questionnaire about damages does not represent a major inefficiency. In some cases, however, where all plaintiffs are identically situated, the notice requirement continues to impose significant inefficiencies by requiring multiple mailings where one would suffice.

The fact, however, that Eisen is frequently circumvented is no justification for continued adherence to the case. It would be preferable to retain the Eisen requirement for class actions in which cost of notice is small relative to the size of the claims, but to jettison it for large-scale, small-claim class actions. ${ }^{103}$ In such cases it should be sufficient for the court to order publication notice and individual notice for relatively large claims, but to defer individual notice to small claimants until after judgment or settlement. If appropriate, the only notice small claimants need receive is a letter containing a check (or other relief such as vouchers, coupons, or securities) and informing them of the results of the litigation.

\footnotetext{
${ }^{103}$ Determination of whether a particular lawsuit falls within the category of a largescale, small-claim class action can appropriately be left to the discretion of the trial court. It would not be difficult, however, to develop a serviceable definition by rule for purposes of administering the notice requirement. For example, one could define the category as encompassing class actions in which at least 1,000 class members are alleged to suffer injuries. smaller than $\$ 250$. Individual notice would not have to be sent to these individuals with small claims. If, however, a subclass of plaintiffs with injuries exceeding $\$ 250$ each can reasonably be identified, then it would be appropriate for the court to order individualized notice for these larger claimants. The use of subclasses for notice would be particularly useful in the securities context, which often involves a large number of individual investors with small claims and a relatively small number of institutional investors with larger claims. Notifying such larger claimants would serve due process values, and would also facilitate potential monitoring of the plaintiffs' attorney by sophisticated claimants with relatively substantial stakes.
}

See also the 1977 proposal by the Justice Department's Office for Improvements in the Administration of Justice, which would have established a special procedure for class actions in which the number of class members exceeds 200 , each injury is not greater than $\$ 300$, and damages equal $\$ 60,000$ or more in the aggregate. See Note, Notice Cost Problems Under Rule 23(b)(3) and (c)(2) after Oppenheimer Fund, Inc. v. Sanders, 1979 Duke L J 882, 906 (citing Office for Improvements in the Administration of Justice, United States Department of Justice, Effective Procedural Remedies for Unlawful Conduct Causing Mass Economic Injuries (1977)). 


\section{B. Control of Derivative Litigation}

The preceding discussion has concerned only control of litigation by absent plaintiffs in the class action setting. Different but analogous problems arise in shareholder's derivative litigation. The differences stem from the distinctions already noted between derivative and class action litigation. ${ }^{104}$ These differences between class action and derivative suits generate different dynamics as to control of the lawsuit by the absent client. In the derivative context the problem is not that the client-the corporation-is uninterested and disorganized. To the contrary, the client is typically both highly organized and very interested. Rather, the problem is that the client is under the control of parties-namely corporate managers-who are hostile to the litigation. If the client were allowed free rein to control the lawsuit, the derivative action would be vitiated as a corporate control mechanism: the corporate management would routinely cause the suits to be dismissed or compromised on terms favorable to them but not necessarily favorable to the corporation or its shareholders.

In an attempt to alleviate this problem, the regulatory system divides control of the litigation between the corporation and the derivative plaintiffs' counsel. This allocation of control manifests itself in rules governing director demand and special litigation committees. These rules allow the corporate management to control the litigation when such control would be in the best interest of the corporation. When management control ceases to be in the corporation's interest, the rules permit the derivative plaintiffs' attorneys to take over. We believe that these rules work reasonably well as a means of controlling the entrepreneurial attorney.

\section{Director demand.}

Under Delaware law, as under the law of virtually all the states, a derivative suit plaintiff is required to make a demand on directors that they cause the corporation to institute the lawsuit in question unless such a demand would be futile. ${ }^{105}$ Demand is ex-

104 See notes 11-16 and accompanying text.

${ }^{105}$ See Del Chanc Ct $R$ 23.1. For an insightful analysis of the demand requirement, see Comment, The Demand and Standing Requirements in Stockholder Derivative Suits, $44 \mathrm{U}$ Chi L Rev 168 (1976).

Federal Rule of Civil Procedure 23.1, which requires particularized allegations as to whether demand was made, is sometimes referred to as containing a demand "requirement" but it clearly does not. Such a requirement would raise serious questions as to the rule's constitutionality under the Erie doctrine, because director demand appears substantive for 
cused only where the directors have a personal interest in the litigation that is adverse to the corporation. What follows is an evaluation of the demand requirement as a device for controlling agency costs in derivative suits.

a) Demand required cases. From the standpoint of economic analysis, the demand requirement appears quite justifiable as applied to cases in which the directors are not so personally interested in the litigation as to make them unreliable champions of the corporate interest. It seems obvious that corporate directors are better situated than plaintiff's' attorneys to initiate and control litigation to enforce corporate rights.

The directors have a greater stake in the corporation and accordingly are in most cases aligned in interest with the shareholders. Directors usually own some stock in their corporations and are interested in preserving their reputational capital by not being associated with firms that perform poorly. Representative shareholders, on the other hand, may have only a minimal interest in the corporation, especially if their shareholdings are small or part of a highly diversified portfolio. Moreover, representative shareholders, like named class plaintiffs, typically exercise virtually no control over the activities of the plaintiffs' attorney. The real party in interest is an attorney with no stake in the corporation at all other than an interest in extracting a fee from it.

The directors possess far greater expertise to evaluate the corporation and its affairs than do plaintiffs' attorneys. This expertise can be used to analyze whether litigation would be in the corporation's best interest. It is not difficult to imagine cases in which, while the corporation may have a potential right of action against another person, the best interests of the shareholders would not be served by immediate recourse to the courts. The potential defendant may be involved in complex and long-term relationships with the corporation-relationships that provide opportunities for adjusting disputes cheaply and effectively outside the formal legal process. Litigation may harm the corporation because sensitive business information will have to be disclosed in discovery. Litigation will tie up time and energies of corporate managers that might better be spent on other tasks. There are many good reasons of business judgment for a corporation not to bring suit even though

Erie purposes. The better view is that the rule simply states the type of allegations that must be made in federal court to satisfy the court that the demand requirement arising under some applicable substantive law has been satisfied. 
it may have a colorable right of action, or even though an outside attorney considers the matter sufficiently promising to warrant bringing the suit on a contingent basis.

Finally, the directors are chosen by shareholders, whereas the plaintiff's' attorney is a volunteer. There is no reason to suppose that the plaintiffs' attorney is the best person to conduct the litigation simply because she happened to identify it and indicated a willingness to take it on. Thus, other things equal, it would appear preferable to allow the directors to pick the attorney, rather than permitting an attorney to acquire the right to litigate the corporation's claim simply by volunteering.

These reasons provide overwhelming support for a rule requiring a plaintiffs' attorney to make a demand on the directors before bringing a derivative suit in situations where the directors do not face a conflict of interest in their decision. If the directors decide to institute suit after receiving the demand, the action is taken over by the corporation, which is presumably better situated to bring the action than plaintiffs' counsel. If the directors refuse the demand, this determination is ordinarily final unless the shareholder can establish that directors did not act out of informed business judgment. ${ }^{108}$

The demand requirement does have costs. For example, the rule deters the flow of beneficial information to corporate directors because to the extent that they expect the corporation to take over the litigation, outside attorneys are unlikely to research potential corporate causes of action or to bring known claims to the attention of the directors. This cost is presumably relatively slight, given that insiders are in the best position to research the corporation's rights. Furthermore, there will be cases in which the existence of a potential plaintiff waiting in the wings, as it were, will benefit the corporation because directors can use the threat of litigation in order to extract larger concessions from potential defendants. Yet the existing regulatory system does not provide a reliable means by which potential derivative plaintiffs can be compensated for their services to the corporation in threatening litigation; accordingly, such services are unlikely to be provided as often as the corporation might wish. One useful reform might be to

${ }_{108}$ Zapata Corp. v Maldonado, 430 A2d 779, 784 (Del 1981). For a different approach to judicial review of the directors' refusal of demand in federal common law cases, see Kamen v Kemper Financial Services, Inc., 908 F2d 1338, 1343-44 (7th Cir 1990), cert granted, 111 S Ct 554 (1990) (no special deference owed to directors' decision in demandrefused cases). 
allow potential deriviative plaintiffs to recover compensation for the benefit of their services in such cases, but it would often be difficult if not impossible to determine the value of the potential plaintiff's contribution.

Despite these costs, however, the demand requirement appears fairly well-crafted to maximize corporate welfare in cases where the directors do not have a personal interest in the potential litigation that is possibly adverse to the interest of the corporation.

b) Demand excused cases. Where, however, the directors are personally interested in and hostile to the litigation, they cannot be relied on to serve the best interests of the corporation. The demand requirement ceases to serve its intended purpose. The classic case, as already noted, is that in which the directors or other top corporate managers are the potential defendants in a suit for breach of fiduciary duty. A rigid demand requirement would be counterproductive because self-interested directors could use their powers under the demand rule to derail the litigation, by, for example, delaying their response to the demand, taking over the litigation and then dismissing it, or compromising it on terms favorable to their own interests.

Delaware corporate law, like that of other states, copes with this situation in a relatively sensible fashion by excusing demand when the plaintiffs' well-pleaded allegations, taken as true, raise a reasonable doubt as to (1) the disinterestedness or independence of a majority of the board, or (2) the directors' exercise of proper business judgment in approving the challenged transaction. ${ }^{107}$ Stated as a general rule, this approach appears to be quite carefully crafted to carve out a limited territory in which the benefits of director demand are outweighed by the possibility that interested directors will abuse their rights under the demand requirement to the detriment of the corporation. In these situations, it is better for the litigation to be turned over to the derivative plaintiffs' attorney for zealous prosecution.

Much depends on the way in which the rule is implemented in practice, however. The deferential "abuse of discretion" standard of judicial review of decisions dismissing derivative complaints for

${ }_{107}$ See Grobow v Perot, 539 A2d 180, 186 (Del 1988); Pogostin v Rice, 480 A2d 619, 624 (Del 1984); Aronson v Lewis, 473 A2d 805, 818 (Del 1984). As a procedural matter, demand excused cases are handled by the provision in both FRCP 23.1 and Del Chanc Ct R 23.1 permitting the representative plaintiff to allege the steps "if any" she took to obtain the action desired as well as the "reasons . . . for not making the effort." 
failure to make demand ${ }^{108}$ raises a possibility that chancery court judges may sometimes manipulate the demand rules to dismiss cases they want to dispose of for other reasons.

\section{Special litigation committees.}

The demand requirement is the principal means for involving the putative client-the corporation-in the fundamental litigation decisions in a derivative suit. Even if demand is excused as futile, however, corporate managers may seek to reenter a derivative lawsuit at a later date by constituting a special litigation committee of presumptively impartial directors that may then seek to wrest control of the litigation away from plaintiffs' counsel.

In the classic case of Zapata Corp. $v$ Maldonado, ${ }^{109}$ a derivative action for breach of fiduciary duty was brought against ten officers or directors of the Zapata Corporation. Four years after the suit was commenced, the director-defendants appointed two new "outside" directors and constituted them as an "Independent Investigation Committee" to investigate the lawsuit and determine what action the corporation should take. The committee determined that the derivative action was inimical to the corporation's best interest and should be dismissed. The Delaware Supreme Court held that a corporate board retains a degree of power to manage derivative litigation even if demand is excused as futile at the outset of the litigation. The relevant inquiries for the trial court are, first, whether the special committee acted independently and whether its conclusions had reasonable factual basis, ${ }^{110}$ and, second, whether the court determines, in the exercise of its own business judgment, that the corporation's motion to dismiss should be granted. ${ }^{111}$

Zapata has something to recommend it, in that the court attempted to devise a reasonable compromise that would maximize the likelihood of outcomes beneficial to the corporation. If the continued conduct of a particular derivative lawsuit would indeed be inimical to the best interests of the corporation, the policies underlying the derivative lawsuit would best be served by allowing dismissal of the action. An independent committee of the board of

\footnotetext{
108 See Grobow, 539 A2d at 186.

100430 A2d 779 (Del 1981).

110 Id at 788 .

${ }^{111}$ Id at 789. See also Joy $v$ North, 692 F2d 880, 892-93 (2d Cir 1982) (analyzing standards for applying the court's own business judgment).
} 
directors would appear to be a reasonable body in which to vest that dismissal power.

The court in Zapata, however, was rightly sensitive to the possibility that sham committees of "outside" directors who were actually under the influence of corporate insiders could terminate a derivative action that was in fact in the best interests of the corporation. The court attempted to deal with this danger by requiring the trial court to exercise its own business judgment in reviewing the actions of special committees, rather than deferring to the business judgment of the committee, as would be the rule for other types of corporate action. The virtue of the Delaware Supreme Court's approach is that it does not rely on barren generalizations or rigid applications of traditional litigation rules to the unique context of derivative litigation. Rather, the court's allocation of litigation authority between the directors and plaintiffs' attorneys attempts a realistic accommodation of competing considerations in light of the underlying economic rationale for derivative litigation, as well as the agency problems that confront plaintiff-shareholders and their attorneys.

However, the rule in Zapata suffers from several shortcomings. First, the court did not articulate with any precision the substantive standard that a trial court should apply in exercising its own business judgment. Thus, there is an unfortunate element of indeterminacy in the Zapata test. Trial courts might find the Zapata test a convenient means for disposing of cases on the merits, even though conceptually the business judgment analysis should not reflect the court's evaluation of the case on the merits but rather whether the control of the litigation should be left in the derivative plaintiffs' attorney's hands.

Second, the idea that a trial court can exercise "business judgment" is anomalous. Trial judges are not businesspeople; they do not possess the practical experience and exposure to the special needs of the corporation that characterizes the business judgment of corporate managers. The court's reference to "business judgment" may well implicitly bias the analysis in favor of management. The trial court will naturally feel an inclination to defer to the views of corporate directors, who do exercise business judgment in other contexts, as to whether the continuation of the litigation would be in the best interest of the firm.

A more appropriate rule for evaluating the recommendations of special litigation committees could easily be crafted using the common jurisprudential devices of substantive standards and burdens of proof. The appropriate substantive standard is whether the benefits to the corporation of continuing the litigation exceed the 
costs of doing so. ${ }^{112}$ Observe that this standard is quite different from an analysis of the merits of the litigation. ${ }^{113}$ In many cases the standard could be met even though the corporation has a relatively low probability of success on the merits. If, for example, the corporation has only a 20 percent chance of victory, but stands to win a net judgment (after deducting the fees of the plaintiffs' attorney) of $\$ 10$ million if it does win, then the approximate value of the case to the corporation ex ante is $\$ 2$ million. In such a case, the derivative litigation should be dismissed only if the costs to the corporation from continuing the litigation exceed $\$ 2$ million. These costs would not include attorneys' fees, the major component of expenses in most standard litigation settings, because no fees will be owed if the case fails and the fees in the event of success are already included in the calculation.

Application of this substantive standard depends on difficult questions of proof and complex factual inferences. Thus much turns on the burden of proof. In our view, the burden should be on corporate management to demonstrate that the costs of continuing the litigation exceed the benefits. Even though the special litigation committee is ostensibly independent, it is clear that in many cases the independent directors have close ties with the defendant directors. ${ }^{114}$ Further, by prosecuting the litigation, the plaintiffs' attorney demonstrates in a highly reliable way that the suit has favorable prospects for generating value for the corporation. The fact pattern suggests a probability that the litigation is indeed in

112 See Joy, 692 F2d at 892. A court's investigation of these matters need not be limited to an analysis of whether the procedures and methodologies used by the special litigation committee were appropriate. The question of whether litigation is in the corporation's best interest would appear to be well within a court's analytical capacities. Indeed, a court is probably better situated to make this investigation than a special litigation committee in many cases. We disagree, therefore, with the New York approach to special litigation committees, which restricts the judicial inquiry to matters of procedure and methodology. See Auerbach $v$ Bennett, 47 NY2d 619, 393 NE2d 994, 1002-03 (1979).

113 See Joy, 692 F2d at 892 (The point of the Zapata analysis is "not to render a decision on the merits, fashion the appropriate legal principles or resolve issues of credibility ... The court's function is thus not unlike a lawyer's determining what a case is 'worth' for purposes of settlement.").

${ }_{114}$ See id at 888; Miller v Register and Tribune Syndicate, Inc., 336 NW2d 709, 716-18 (Iowa 1983); James D. Cox and Harry L. Munsinger, Bias in the Boardroom: Psychological Foundations and Legal Implications of Corporate Cohesion, 48 L \& Contemp Probs 83, 103-04 (Summer 1985). Delaware Chancellor William Allen has recently recognized that outside directors are often closely affiliated with management and therefore do not always provide an effective check against abuse. See William T. Allen, Independent Directors In MBO Transactions: Are They Fact or Fantasy?, 45 Bus Law 2055, 2056-58 (1990) (arguing, however, that outside directors may operate as an effective check). 
the corporation's best interest. The burden of proof should be on those parties seeking to demonstrate that it is not.

A final question concerns the payment of the costs of the independent committee. These costs may be substantial, since the committee ordinarily retains highly qualified counsel to conduct an extensive investigation into the litigation. ${ }^{115}$ In our view, these costs should not automatically be paid by the corporation. If the special litigation committee operates as a tool of the defendant directors, rather than an impartial fiduciary of the corporate interests, it would be appropriate to require the defendants to pay the costs of the committee in the event they are eventually held liable. Assessment of the special litigation committee's costs, like other costs of the litigation, should be committed to the discretion of the trial court.

\section{Conflicts Between Representative Plaintiffs and Plaintiffs' Attorneys}

A third situation in which control over litigation becomes problematic arises when the named plaintiff actually asserts rights to control the litigation rather than passively allowing her name to be used as the "key to the courthouse door."116

Cases presenting overt conflict between the named plaintiff and plaintiffs' counsel in both class actions and derivative suits are relatively uncommon for obvious reasons. First, because the named plaintiff has only a small stake in the outcome of the litigation, it is usually not worthwhile for her to follow the litigation or go to the trouble of challenging counsel. Second, the named plaintiff is almost always chosen by the attorney. ${ }^{117}$ Plaintiffs' attorneys are unlikely to use as a named plaintiff someone they know to be quarrelsome, at least if they can find a more compliant person. Nevertheless, conflicts between the named plaintiff and plaintiffs' counsel do arise, ${ }^{118}$ and when they do the courts face the dilemma of how to resolve them.

115 See, for example, Kaplan $v$ Wyatt, 484 À2d 501, 511 (Del Chanc 1984), aff'd, 499 A2d 1184 (Del 1985) (special litigation committee interviewed more than 140 people worldwide, and law firm retained by the committee expended between 2,000 and 5,000 hours of attorney time and received compensation of approximately $\$ 500,000$ ).

${ }_{126}$ Saylor $v$ Lindsley, 456 F2d 896, 900 (2d Cir 1972).

${ }^{117}$ See Coffee, 86 Colum L Rev at 681 (cited in note 4).

118 See, for example, Reed $v$ General Motors Corp., 703 F2d 170, 171 (5th Cir 1983) (23 out of 27 named plaintiffs and 40 percent of class objected to settlement agreement); Officers for Justice v Civil Service Comm'n, 688 F2d 615, 618, 623 (9th Cir 1982) (one of eleven named plaintiffs objected to settlement through retained private counsel); Parker $v$ 
In traditional litigation the issue would be simple. As noted already, ${ }^{119}$ the standard model views the lawyer as agent of the client. The lawyer must defer to the client's wishes or withdraw from the representation. There are no exceptions in the Model Code or Model Rules for class action or derivative cases. Read literally, the ethics codes require class action and derivative lawyers to defer to the named plaintiff's wishes.

Such a literal reading, however, would be inappropriate in this context. The client's control in traditional litigation settings is justified by the fact that the client is the best representative of her own interests. In class and derivative litigation, however, the named plaintiff cannot reliably be assumed to be the best representative of the class's interest. Because the named plaintiff's interest in the litigation is much smaller than that of the class as a whole, the alignment between named plaintiff and class or corporation can easily be swamped by other factors. The named plaintiff may have a personal interest in the litigation flowing from sources as diverse as ideology, spite, vanity, or the wish to obtain a disproportionate share of the settlement fund. Further, the named plaintiff is subject to possible influence from defense counsel or counsel in the plaintiffs' consortium who are at odds with the named plaintiff's counsel. And the named plaintiff herself might extort benefits from her counsel by threatening to dismiss the counsel or to make inappropriate litigation decisions. Although the named plaintiff must provide "adequate" representation of the class and must have a claim that is "typical" of the class claims, these requirements are neither effective regulatory devices ${ }^{120}$ nor effective means of protecting the absent class members. These dangers suggest strongly that absent class members would not be adequately protected if the named plaintiff were given unilateral control over the litigation.

On the other hand, a rule that would exclude the named plaintiff from any control rights in the event of disagreement with class counsel would present countervailing considerations. Given the named plaintiff's strong incentive to remain passive and allow counsel to control the litigation, there is good reason for concern about counsel's performance when the named plaintiff brings a dis-

Anderson, 667 F2d 1204, 1207 (5th Cir 1982); Pettway v American Cast Iron Pipe Co., 576 F2d 1157, 1167 (5th Cir 1978).

110 See notes 21-52 and accompanying text.

${ }^{120}$ We discuss the typicality and adequacy requirements at length at notes 250-92 and accompanying text. 
pute to the attention of the court. ${ }^{121}$ In some circumstances class counsel may be a less reliable advocate of the class's interests than the named plaintiff. The most obvious case is where the attorney stands to earn a substantial fee immediately by not appealing, but must wait for payment and expend additional effort if an appeal is taken. In such cases, at least where the appeal does not present significant downside risks for the class, allowing class counsel unilaterally to cut off appeal rights for the class over the objections of the named plaintiff does not adequately protect the interests of absent class members.

These problems are illustrated by the leading case in this area, Pettway $v$ American Cast Iron Pipe Co. ${ }^{122}$ Pettway was an employment discrimination class action in which the named plaintiffs and a number of class members wished to appeal the trial court's judgment denying backpay to a substantial proportion of the plaintiff class. The court articulated a sensible test for sorting out the respective litigating powers of named plaintiff and plaintiffs' attorney:

The proper exercise of the district court's discretion [in determining whether to substitute class counsel at the behest of the named plaintiff] will depend on the facts and circumstances of each case. Among the factors that should be considered by the court are (1) the adequacy of representation of the named plaintiffs, including any apparent or potential conflicts of interest they might have with the remainder of the class, (2) the extent to which other class members support or oppose the [decision], and the extent to which [the action in question] may be necessary to protect the interests of absent class members, (3) the adequacy of representation provided by the class attorney and any conflicts of interest between the class attorney and the class, and (4) the reasonableness of the decision ... including an assessment of the possibility of success on the merits. ${ }^{123}$

${ }^{121}$ See Saylor, 456 F2d at 900 (emphasizing importance of consultation with named plaintiff over important litigation decisions).

${ }^{132} 576$ F2d 1157 (5th Cir 1978).

${ }^{12 s}$ Id at 1178. With regard to the second factor, see Kincade $v$ General Tire \& Rubber Co., 635 F2d 501, 504 (5th Cir 1981). The fourth factor suggests that courts should be wary of allowing named plaintiffs to upset settlements on the merits if the court determines such settlements to be substantively fair to the class. See, for example, Officers for Justice, 688 F2d at 615; McDonald v Chicago Milwaukee Corp., 565 F2d 416, 426 (7th Cir 1977); County of Suffolk $v$ Long Island Lighting Co., 710 F Supp 1428, 1437 (E D NY 1989). 
Applying this test, the court of appeals held-correctly, in our view-that the appeal should be allowed even over the objection of class counsel. The interest of the named plaintiffs in backpay was substantial, and did not differ in any obvious way from the interests of other class members who had been denied backpay relief. Many of class members objected to the attorney's decision. The attorney had a clear conflict of interest; an appeal would require additional attorney time and effort and (apparently) would delay the receipt of attorney's fees. And the appeal presented substantial potential benefits and little downside risk for the class members who had been denied backpay. All of the factors bearing on allocation of litigating authority strongly pointed toward overriding class counsel on the circumstances of that case.

As illustrated by the Pettway case, the existing regulatory system contains a reasonable set of rules for allocating litigating authority between named plaintiffs and plaintiffs' attorneys-rules that are not subject to the defect of being forcibly assimilated with the regulatory structure applicable in other litigation settings, in which the client's decisions on basic strategy are final.

\section{Judicial Review of Settlements and Fee Requests}

So far we have discussed the allocation of decisionmaking authority between the plaintiffs' attorney and (1) absent class members in class actions, (2) the corporation in derivative suits, and (3) named or representative plaintiffs in both types of actions. Now we address the role of the trial court in reviewing settlements and requests for attorneys' fees.

1. Judicial review of settlements.

Most class action and derivative litigation is settled prior to judgment. ${ }^{124}$ When such litigation is settled, the problem of agency costs appears in a particularly problematic form. As already discussed, the plaintiffs' attorney often faces a severe conflict of interest in settling class and derivative litigation. In common fund cases where the attorney earns a percentage of the judgment, the attorney has an incentive to settle early at a relatively low figure in order to maximize her profit. ${ }^{125}$ In common fund cases in which the

\footnotetext{
124 See Thomas M. Jones, An Empirical Examination of the Resolution of Shareholder Derivative and Class Action Lawsuits, 60 BU L Rev 542, 544-45 (1980); Note, 89 Harv I Rev at 1536 (cited in note 85).

${ }^{125}$ See notes 71-72 and accompanying text.
} 
attorney is compensated according to the lodestar formula, the attorney has an incentive to delay reaching a settlement in order to increase the hours upon which the compensation is calculated. ${ }^{128}$ The attorney may also agree to an inappropriately low settlement on the merits in exchange for the defendant's implicit or explicit promise to allow the attorney to expend additional risk-free hours in order to build up a fee. ${ }^{127}$ In common benefit and fee-shifting cases the attorney has an incentive both to delay settlement and to agree to inappropriately low settlements in exchange for generous negotiated attorney's fees. ${ }^{128}$ The plaintiffs' attorney may also attempt to direct a disproportionate share of the settlement fund to the named plaintiff in order to compensate her for acting as representative of the class or corporation. ${ }^{\mathbf{1 2 9}}$

The regulatory response to these conflicts is to require judicial scrutiny of proposed settlements. ${ }^{130}$ Unfortunately, judicial approval appears to be highly imperfect as a protection for the plaintiffs' interests, for a several reasons. ${ }^{131}$ First, and most important, the judge herself has a powerful interest in approving the settlement. Judges' calendars are crowded with cases, and despite various reform efforts, ${ }^{132}$ the workload only seems to increase. ${ }^{133}$ If the

${ }^{128}$ See note 63 and accompanying text.

${ }^{127}$ See notes 64-65 and accompanying text.

${ }^{128}$ See notes 76-79 and accompanying text.

120 See, for example, Holmes $v$ Continental Can Co., 706 F2d 1144, 1146 (11th Cir 1983) (half of class backpay award went to 8 named plaintiffs in class of 126; 39 other class members objected to settlement); Franks $v$ Kroger Co., 649 F2d 1216, 1225 (6th Cir 1981) (reversing a settlement in which the two named plaintiffs had received a total of $\$ 10,500$ and the plaintiff' counsel received $\$ 47,000$ in fees, while other class members received only employer's general agreement to treat its employees equally and a chance to present their individual claims before a magistrate).

130 See FRCP 23(e) ("A class action shall not be dismissed or compromised without the approval of the court, and notice of the proposed dismissal or compromise shall be given to all members of the class in such manner as the court directs."); FRCP 23.1 (derivative action "shall not be dismissed or compromised without the approval of the court, and notice of the proposed dismissal or compromise shall be given to shareholders or members in such manner as the court directs").

${ }^{131}$ See generally Coffee, 48 L \& Contemp Probs at 26-27 (cited in note 4); Judith Resnik, Judging Consent, 1987 U Chi Legal F 43, 101; Wolfram, 47 L \& Contemp Probs at 299 (cited in note 45); Note, Abuse in Plaintiff Class Action Settlements: The Need for $a$ Guardian During Pretrial Settlement Negotiations, 84 Mich L Rev 308, 310 (1985). For one of the more dubious settlements on record, approved by an able federal district judge, see In re Cuisinart Food Processor Antitrust Litigation, 38 Fed Rules Serv 2d 446, 449, 454-56 (D Conn 1983) (antitrust defendant agreed in settlement to give members of the plaintiff class coupons entitling them to purchase accessories directly from manufacturer at 50 percent discount from retail price; court rejected arguments by objecting class members that the settlement constituted marketing gimmick).

132 For discussion of whether caseload growth can be slowed by reducing court backlog, see George L. Priest, Private Litigants and the Court Congestion Problem, 69 BU L Rev 527 (1989).

133 See Richard A. Posner, The Federal Courts: Crisis and Reform 59-129 (Harvard, 1985); Report of the Subcommittee on the Role of the Federal Courts and Their Relation- 
judge approves the settlement, the result will be to remove a potentially complex and time-consuming case from the judge's calendar; if she rejects it she faces a substantial probability of further litigation. A judge faces virtually no prospect of reversal for approving a settlement, whereas a decision rejecting a settlement might well be appealed. Moreover, trial judges are heavily conditioned by the ethos of their jobs to view settlements as desirable; they routinely encourage settlement in other contexts. ${ }^{134}$ It would be unrealistic to expect trial judges to shift gears suddenly and view settlements with suspicion rather than approbation when they arise in the class action or derivative contexts.

Second, trial courts may simply lack information to make an informed evaluation of the fairness of the settlement. ${ }^{135}$ Typically, when a case is settled well in advance of trial, the only information available to the judge is found in papers filed in court-pleadings, briefs, and supporting materials filed on motions-and materials submitted to the judge in connection with the settlement hearing. Such evidence is likely to be highly incomplete and, in the case of materials submitted to support the proposed settlement, biased in favor of the settlement. ${ }^{136}$ The matters on which the judge must rule are also highly subjective and imprecise. Even if the judge had adequate information on which to decide, it would be difficult to make reliable estimates of the settlement value of a case.

Third, settlement hearings are typically pep rallies jointly orchestrated by plaintiffs' counsel and defense counsel. Because both parties desire that the settlement be approved, they have every incentive to present it as entirely fair. Objectors to the settlement, on the other hand, are uncommon; those who do object are often either disgruntled plaintiffs' attorneys who have fallen out with others in the plaintiffs' consortium, or naive class mem-

ship to the States, in 1 Federal Courts Study Committee: Working Papers and Subcommittee Reports 23-39 (July 1, 1990) (documenting enormous workload growth in the federal courts). The adverse psychological effect of these workload pressures on federal judges is apparently quite strong. See id at 40-45, 88-91.

${ }^{134}$ See FRCP 16(a)(5) (one objective of pretrial conferences is "facilitating the settlement of the case") and accompanying Advisory Committee Note.

135 See Note, 84 Mich L Rev at 321 (cited in note 131) (courts lack information about settlement value).

136. See Note, 89 Harv L Rev at 1558 (cited in note 85) (judge's lack of information may interfere with guardianship role). The judge could, of course, request additional information from the parties, but doing so would simply impose additional burdens on the judge without any assurance of a corresponding increase in the information available. 
bers who demonstrate their ignorance of the issues in dispute. The deck is heavily stacked toward approval of the settlement.

Trial courts happily play along with the camaraderie. In approving settlement, courts often engage in paeans of praise for counsel $^{137}$ or lambaste anyone rash enough to object to the settlement. ${ }^{138}$ Not surprisingly, it is uncommon to find cases where trial courts reject settlements that are presented to them by defense counsel and plaintiffs' attorneys. Given that settlements are nearly always approved, one might well question the efficacy of judicial review of class action and derivative settlements.

One possible reform of the existing system, which has been proposed by a few commentators, ${ }^{139}$ would be to appoint a guardian ad litem to represent the interests of the class during the settlement process. The guardian would be expected to object to settlements almost as a matter of course, or else to provide the court with a statement of why, in the guardian's opinion, the settlement, is fair to the plaintiff class. But guardians must be selected by somebody. If the judges and lawyers are biased toward settlement they are likely to select passive and compliant guardians. We believe, however, that the guardian proposal carries some promise, in that the court will hear the views of a presumably able advocate on behalf of absent class members, something that is almost entirely missing under current practice. The guardian could have access to discovery provided in the case, and would have the right to bring additional information to the attention of the trial court. Even if guardians did not succeed in increasing settlement amounts in more than a fraction of cases, their very presence in the litigation might encourage counsel to avoid settlements that are overly unfa-

197 See, for example, Mashburn v National Healthcare, Inc., 684 F Supp 660, 672 (M D Ala 1988) (taking judicial notice, in approving proposed settlement, that plaintiffs' counsel was "one of the most able and experienced trial lawyers in the State of Alabama"); Cuisinart, 38 Fed Rules Serv 2d at 453 (court trusted counsel's estimates of litigation costs because of the "experience and competence of counsel, on which the court ha[d] commented favorably on other occasions").

138 See, for example, Holden v Burlington Northern, Inc., 665 F Supp 1398, 1431 (D Minn 1987) ("Objectors['] proper concern for the class has unfortunately turned into an unbecoming personal invective. Objecting counsel have been obstreperous, as well as professionally insulting to their colleagues. They have leveled vicious and wholly unwarranted attacks upon their opposition. These assaults have neither enlightened the court nor enobled those who have made them.").

130 See Note, 84 Mich L Rev at 310-11 (cited in note 131). See also Josef D. Cooper and Tracy Kirkham, Class Action Conflicts, 7 Litigation 35, 36, 60 (Winter 1981) (suggesting possible utility of guardianship but noting difficulties with the idea); Note, 89 Harv L Rev at 1561-66 (cited in note 85) (suggesting need for an "absentee advocate" to monitor negotiations on behalf of class members not before the court). 
vorable to the plaintiff class, particularly if the guardian were given an economic incentive to oppose the settlements. Guardians might also have a salutary effect on judges by reducing their proclivity to approve all settlements.

On the other hand, a guardianship is not costless. Someone must pay the guardian's fee. The fee cannot be paid, at least initially, out of the settlement amount, because whether there will be a settlement is exactly the question in dispute. Nor would it be desirable to give the guardian a contingent interest in the settlement fund, because this would create a perverse incentive for the guardian to support settlements in order to assure a fee. The problems of funding the guardianship procedure are serious, although not insurmountable. More fundamentally, a guardianship would be desirable only if the benefits of such a mechanism exceed the costs, however those costs are paid. It is not obvious that a guardian would have a sufficient impact on the litigation to warrant the expense. However, the proposal does seem sufficiently attractive to justify an experiment with guardianship, perhaps in a single judicial district for a limited time period, to evaluate whether the benefits do in fact exceed the costs. ${ }^{140}$

\section{Judicial review of fee requests.}

In contrast to judicial review of settlements, where courts have acted more or less as rubber stamps, fee requests by plaintiffs' attorneys have at times received far more exacting judicial scrutiny.

It would appear that the degree of scrutiny given fee requests correlates closely with whether the request is presented to the judge as part of a settlement on the merits. Judges rarely reject fee petitions presented as part of a settlement. If they reject a fee settlement, they may find themselves wading through affidavits and time sheets in an effort to determine the appropriate fee themselves, something most trial judges would prefer to avoid. Worse, if the fee agreement is presented as part of a comprehensive settlement package, the trial judge risks upsetting the entire compromise if she rejects the fee request. Far better to approve the fee than to buy this kind of trouble. Moreover, fee petitions that are presented as part of a settlement package have in theory been bar-

140 Guardians have been appointed at the discretion of the trial courts in a few prior cases, but to the best of our knowledge no systematic program has yet been implemented. For cases using guardians on an ad hoc basis, see Haas v Pittsburgh National Bank, 77 FRD 382, 383-84 (W D Pa 1977); Miller v Mackey International, Inc., 70 FRD 533, 535 (S D Fla 1976). 
gained out between the attorneys for the opposing sides; they have the imprimatur of adversary testing. To be sure, the bargaining process is not entirely at arm's length; experienced trial judges are well aware of the possibility of tradeoff between attorneys' fees and merits relief. Yet this agency cost is rarely sufficient to upset a negotiated settlement given the other advantages the negotiated fee presents from the judge's point of view.

When the fee request has not been settled out, either because the attorneys cannot agree on the fee or because the fee is to be taken out of a common fund as to which the defendant has no settlement authority, judges often do reduce the fees requested by plaintiffs' attorneys by substantial amounts. ${ }^{141}$ This more searching judicial treatment appears to stem from several factors.

First, fee requests typically present the conflict between plaintiffs' attorney and client in the most vivid form. Especially in common fund cases, money awarded to the attorney comes directly out of the fund that would otherwise go to the class or corporation. Even in common benefit and fee-shifting cases the possibility of tradeoff between attorneys' fees and merits relief is readily visible to any experienced trial judge. The greater prominence of attorney-client conflicts in this setting may partially account for the heightened judicial scrutiny of fee requests.

Second, in common benefit and fee-shifting cases, the defendant is sometimes present in court strenuously objecting to the requested fee. Thus, some fee hearings are true adversary proceedings rather than the cheerleading sessions typical of settlement hearings. Predictably, judges are more likely to examine fee petitions closely in such cases, and to pare down requests that look excessive.

Third, trial courts have much less to lose by upsetting fee requests than by rejecting settlements. Unlike rejections of settlements, rejections of fee requests do not keep a potentially burdensome case on the judge's calendar. Further, the prospects of appeal are small, at least when the matter at issue is the judge's evaluation of the reasonableness of the hours, the hourly rate, or the multiplier. These are quintessential discretionary judgments that are

141 See, for example, In re Continental Illinois Securities Litigation, 750 F Supp 868 (N D Ill 1990) (drastically cutting fees requested by counsel in major securities litigation); Fox $v$ Glickman Corp., 253 F Supp 1005, 1013-15 (S D NY 1966) (slashing requested fees and chastising counsel for burdening court with disagreements among plaintiffs' attorneys); Robert T. Mowrey, Attorney Fees in Securities Class Action and Derivative Suits, $3 \mathrm{~J}$ Corp Law 267, 292 (1978) ("inability of all attorneys to . . . agree solidly on the size of the fee award has a potentially detrimental effect on the fee application"). 
reviewed on appeal on an abuse of discretion standard. ${ }^{142}$ An appeal will put off the moment when the plaintiffs' attorneys can receive compensation for their services. Since the trial court typically gives the plaintiffs' attorney something, albeit a lower amount than was requested, the rational strategy for plaintiffs' attorneys is usually to accept what they are given.

Fourth, trial courts possibly have something to gain from occasionally exercising their authority to reduce fee requests. The trial court's broad discretion to determine the amount of the fee award gives the judge enormous potential leverage with plaintiffs' counsel to control the conduct of the litigation and to deter conduct by plaintiffs' counsel that the trial court dislikes. A trial judge can maintain a reputation for toughness with the plaintiffs' bar by occasionally knocking down fee requests.

At least under the current system in which lawyers cannot "own" the claims, judicial review of fee requests would appear to be necessary because of the lawyer-client conflicts described above. Yet in addition to the general problems with judicial review of fee awards noted above, there are problems inherent in the methods by which those fees are calculated.

a) Lodestar method. The lodestar method for calculating fees requires the judge to multiply the reasonable number of hours expended by the reasonable hourly fee and then to adjust this "lodestar" amount, as appropriate, to account for special factors such as the risk of nonsuccess in the litigation. ${ }^{143}$

If a judge. is to engage in a bona fide effort to determine a proper lodestar fee, she must first determine the reasonable hours expended. This task involves an initial determination of how many hours were actually expended. The judge can rely to some extent on attorney time sheets, which the Supreme Court has declared to be virtually essential if a plaintiffs' attorney is to receive compensation in fee-shifting cases. ${ }^{144}$ But preparing time sheets is burdensome for attorneys, as is evaluating them for judges. ${ }^{146}$ And time

\footnotetext{
142 See, for example, United States $v$ Mississippi, 1991 WL 281 (5th Cir); Seaman $v$ Vaughan, 1991 WL 281 (11th Cir); Von Clark v Butler, 916 F2d 255, 258 (5th Cir 1990); State of Illinois $v$ Sangamo Construction, 657 F2d 855, 858 (7th Cir 1981); Ellis v Flying Tiger Corp., 504 F2d 1004 (7th Cir 1972).

143 The lodestar calculation is described at note 62 and accompanying text.

14 See Hensley $v$ Eckerhart, 461 US 424, 433 (1983).

${ }^{145}$ For one judge's description of the wearying task, see Continental Illinois, $750 \mathrm{~F}$ Supp 868, 878 (N D Ill 1990) ("I have examined each of the hundreds of pages of time entries submitted in support of the 41,955 hours of attorney and paralegal time claimed in the petition. I have also examined the 16-volume set of appendices containing copies of
} 
sheets can easily be prepared after the fact on the basis of the lawyer's imaginative reconstruction of events. ${ }^{148}$ The determination of the hours actually expended is itself not entirely reliable.

Next, the judge must determine how many hours were reasonable to expend under the circumstances. To do so, presumably, the judge must familiarize herself with the history of the case and place herself in the position of plaintiff's' counsel at each critical step in the litigation. This reconstruction is obviously a difficult undertaking. The judge must determine the reasonableness of the hours expended in light of the unique structural features of plaintiff's' class and derivative litigation, in which the work is typically conducted by a consortium of lawyers and law firms under the general guidance and direction of lead counsel. ${ }^{147}$ The loose structure of plaintiffs' class and derivative litigation suggests the need for a relatively large amount of time spent in coordination and monitoring activities. ${ }^{148}$ Such work does not necessarily represent an ineffciency; it may well avoid even greater expenditure of hours as a result of duplication of effort or lack of coordination. Yet courts are ill-equipped to determine whether the level of coordination and monitoring activities undertaken by lead counsel is appropriate under the circumstances.

The judge's evaluation of the reasonableness of the hours is subject to the bias of hindsight. Avenues of research or litigation strategy that did not pan out might look considerably less sensible after the fact than they did at the time. And judges, no less than the rest of us, undoubtedly often underestimate the amount of time it will take to perform a given task-especially when the task involved is to be performed by others. Judges often disallow hours with what might be seen as less than full-scale analysis of the issue. ${ }^{149}$ At other times they approve without question fee requests

every pleading or memorandum on which more than 20 hours time was spent. It may be that only an exercise of this kind can convince one of the futility of attempting to decide what amount of time was necessarily spent on a case of this breadth and duration.").

${ }^{148}$ See, for example, Report of the Federal Courts Study Committee 104 (April 2, 1990); A. Miller, Attorney's Fees in Class Actions 269 (cited in note 79) (working of excessive hours and inflation of time sheets reported to be common abuses in class action litigation).

${ }^{147}$ See Coffee, $42 \mathrm{Md} L \mathrm{Rev}$ at 248-52 (cited in note 4).

${ }^{148}$ See, for example, In re Anchor Securities Litigation, Fed Sec L Rptr (CCH) II 95,481 at 97,511 (E D NY and S D NY 1990) ("the fact that there were seven different law firms involved required some duplication of effort for different lawyers to become familiar with the lawsuit and for communication between firms").

140 See, for example, Harman v Lyphomed, Inc., 734 F Supp 294 (N D Ill 1990); In re AIA Industries Inc. Securities Litigation, 1988 US Dist LEXIS 2952, *7 (E D Pa). 
which seem extraordinarily high, at least at first blush. ${ }^{150}$ Plaintiffs' attorneys have little means for predicting how many of their hours the judge will allow, other than guesses based on the trial judge's reputation as "tough" or "lenient" on fees. ${ }^{151}$ The assessment of the reasonable hours, in short, is exceedingly inexact and often apparently arbitrary in operation.

Similar, although perhaps less severe, difficulties attend the determination of the reasonable hourly rate. There is no readily determinable, publicly announced market rate for lawyers that a judge can examine to fix the value of a plaintiffs' attorney's services. To determine hourly rates, the judge must evaluate how much lawyers of similar experience and skill charge in the community. Yet the typical judicial inquiry into these matters is superficial at best. Usually the plaintiffs' attorney will submit affidavits from a few lawyers in town as to what their hourly rates are. Those friendly affidavits are not statistically significant, and no doubt state the affiant's public hourly rate without consideration of the possibility of negotiated fees at lower rates. It is, moreover, quite difficult to compare lawyers, evaluating whether one attorney possesses experience and skill similar to another-especially when the attorney providing the affidavit is used to working on an hourly basis while the plaintiffs' attorney operates principally under contingent fee arrangements. The upshot is that judges evaluating reasonable hourly rates utilize only the roughest of proxies for the actual market value of an attorneys' services.

Finally, as if the inquiry to this point were not difficult enough, there is the possibility of a multiplier. If the reasonable hours and reasonable hourly rates are hard to measure, the multiplier calculation is all but standardless. Most jurisdictions accept risk as a factor for consideration, ${ }^{152}$ but the determination of the

150 The reader can draw her own conclusions from the fees in In re Cuisinart Food Processor Antitrust Litigation, 38 Fed Rules Serv 2d 446, 450-52 (D Conn 1983) (approving escrow fund of more than $\$ 700,000$ for fees when attorneys had apparently done little more than file a complaint piggybacking on government enforcement actions, engage in some discovery, and negotiate a settlement).

${ }_{161}$ Judge Weinstein, for example, while favorably inclined toward class action litigation in general, has developed a reputation for being bearish on fees. At present writing, members of the plaintiffs' bar are scrambling to avoid nationwide certification of asbestos personal-injury litigation before Judge Weinstein, apparently because of his reputation on fees. See Stephen Labaton, Judicial Struggle in Asbestos Cases, NY Times D2 (August 6, 1990).

162 The Supreme Court somewhat ambiguously approved the use of risk enhancement in Pennsyluania v Delaware Valley Citizens' Council for Clean Air, 483 US 711 (1987). Justice White's plurality opinion in that case approved the use of risk multipliers only under stringent restrictions including a maximum one-third enhancement. See id at 723-31. Justice O'Connor's opinion concurring in the result suggested a two-part test that first asks 
level of risk is done exceedingly impressionistically. The trial court's assessment of risk, based on presumably ample experience at the bench and bar, is certainly worthy of respect. But trial courts are not particularly well-suited to determining the degree of risk ex ante in a lawsuit. As in the case of the reasonable hours inquiry, they are subject to possible hindsight bias, in that once a case is successful it appears less risky than may have been the case at the outset. ${ }^{153}$ Trial courts may also experience what we might call subjective bias; their assessment of the riskiness of the litigation may be colored by their knowledge of their own contemporaneous assessment of the lawsuit. The trial judge, for example, may have decided early on in the litigation that the plaintiff was virtually certain to win significant relief. At issue, however, is not what the trial court believed, but what the plaintiffs' attorney reasonably believed. Because the plaintiffs' attorney will not know at the time how the trial court views the case, the trial court's contemporaneous evaluation is not particularly relevant to the risk analysis.

Further confusing the risk analysis, some trial courts conclude that if a particular case attracted numerous attorneys, the case could not have been particularly risky ex ante. ${ }^{184}$ This is a fallacy, however, because the number of attorneys in a case is a function of their reasonable expectations-including their expectations of obtaining a risk multiplier if the suit is successful.

The ex ante perspective evokes another fundamental objection to the use of a single multiplier in calculating the fee award. Applying a single risk factor to all the hours expended on the lawsuit is a rough measure, at best, of the true riskiness of the attorneys' activities. During the course of the litigation the attorney will constantly readjust her assessment of the probability of success on the merits and the likelihood of settlement, based on the success or failure of motions, the results of discovery, and the behavior of the

whether the relevant legal market adds a premium for contingency, and, second, whether in the absence of an enhancement for risk the plaintiff would have faced substantial difficulty in finding counsel. Id at 731-34 ( $O^{\prime}$ Connor concurring). At least one lower court has followed her opinion. King $v$ Palmer, 906 F2d 762, 765 (DC Cir 1990).

${ }^{183}$ See Kirchoff $v$ Flynn, 786 F2d 320, 325 (7th Cir 1986) (noting the "inequities of retrospective rate setting").

${ }^{164}$ For example, In re Continental Illinois Securities Litigation, 750 F Supp 868, 895-96 (N D Ill 1990); Anchor Securities, Fed Sec L Rptr (CCH) I 95,481 at 97,511; Harman $v$ Lyphomed, Inc., $734 \mathrm{~F}$ Supp 294, 298 (N D Ill 1990). For cases that get the analysis right, see In re Oracle Securities Litigation, 131 FRD 688, 693 (N D Cal 1990) (suggesting that uncertainty about compensation affects not only the litigation at hand but also incentives to litigate in future comparable cases); In re Folding Carton Antitrust Litigation, 84 FRD 245, 275-76 (N D IIl 1979) (same). 
defendant's attorney. In theory, the multiplier should be adjusted to account for the risk of the litigation at the particular time the hour is spent.

The multiplier, and in particular the risk adjustment, are extraordinarily uncertain in application. Not surprisingly, the cases are all over the map. Courts in some cases award multipliers as high as three or more; ;155 in other cases they deny multipliers at all even though the plaintiffs' attorney's only hope of fees depended on the success of the litigation. No study of which we are aware has identified any consistent pattern in the use of risk multipliers. ${ }^{156}$ Accordingly, as presently administered, the risk multiplier is little short of a wild card in the already uncertain game of assessing fees under the lodestar calculation. ${ }^{167}$

A final problem in this area is that of judicial scrutiny of feesharing agreements among plaintiffs' attorneys. ${ }^{158}$ The leading case here is In re "Agent Orange" Product Liability Litigation. ${ }^{169}$ The court in Agent Orange invalidated an arrangement, which had been freely and voluntarily agreed to by all the plaintiffs' counsel, under which those attorneys who advanced funds to support the litigation would be reimbursed threefold out of the attorneys' fees award if the litigation were successful. The principal grounds for decision were (1) that this agreement distorted the award of fees under the lodestar calculation by awarding counsel who had advanced funds excessive hourly compensation relative to counsel who had not supported the litigation and (2) that the arrangement gave investor-attorneys impermissible incentives to settle early at too low a figure. ${ }^{160}$ The court ruled, further, that all future feesplitting agreements of this type must be disclosed immediately to

${ }^{165}$ See, for example, In re Oak Industries Securities Litigation, 12 Class Action Rep 536 (S D Cal 1986) (multiplier of 4.04); Trustee of the Florence Katz Trust v La Petite Academy, Inc., 12 Class Action Rep 539 (E D Pa 1989) (multiplier of 3.47).

${ }_{18}$ The Federal Courts Study Committee has recently suggested that federal courts might handle the risk of loss by adopting " $a$ uniform enhancement factor or a schedule of factors for different types of cases." Report of the Federal Courts Study Committee at 104 (cited in note 146). While such a uniform treatment would provide consistency and predictability, it would sacrifice accuracy because it would treat many cases alike that in fact are different.

${ }^{167}$ See In re Union Carbide Consumer Products Business Securities Litigation, $724 \mathrm{~F}$ Supp 160, 170 (S D NY 1989) (fixing fees according to the lodestar calculation "often seem[s] to take on the character of so much Mumbo Jumbo").

${ }^{168}$ We here consider the impact of such fee-sharing agreements on the lodestar calculation. See notes 314-17 and accompanying text for discussion of the ethical problems with fee-sharing agreements.

188818 F2d 216 (2d Cir 1987).

${ }^{180}$ Id at $224,225-26$. 
the trial court. ${ }^{161}$ Such agreements will be readily available to challenge by defense counsel in future cases.

The decision in Agent Orange is unfortunate, ${ }^{162}$ especially given Judge Weinstein's able opinion at the trial level, upholding the agreement as being necessary in light of the practical needs for effective representation of class rights. ${ }^{163}$ Judge Weinstein is clearly correct that the fee-splitting agreement should have been upheld. It was, after all, freely agreed to at arm's length by wellinformed and competent parties. There is every reason to suppose that a threefold return on the funds invested was a reasonable compensation in light of the risks involved in the litigation. The noninvestor attorneys who came in after the fact were attempting to upset an agreement that had their full assent ex ante. The fact that the agreement was unpalatable to these attorneys ex post should be entirely irrelevant. To be sure, the attorneys did allocate the lodestar award amongst themselves, but this hardly seems problematic. The purpose of lodestar fees is to compensate attorneys and induce private enforcement of the law; this purpose was fully satisfied by the allocation to which the attorneys had agreed. ${ }^{164}$

The only rationale with even surface plausibility for upsetting the fee allocation agreement is that it compromised the interests of the absent class members, but it did not. On the contrary, it served their interests by providing a means by which the expensive and risky litigation could be continued. The court mistakenly concluded that the agreement created excessive settlement incentives. The enhanced settlement incentives it gave to the investing attorneys were offset by a concomitant decrease in the settlement incentives for the noninvestor attorneys, including the lead counsel. Arguably such an arrangement was far preferable, from the standpoint of the absent class members, to an arrangement under which all members of the plaintiffs' consortium have roughly equivalent settlement incentives. The likely effect of the Agent Orange deci-

\footnotetext{
101 Id at 226.

${ }^{102}$ For a caustic critique of the appeals court's decision, see Coffee, 54 U Chi L Rev at 902-04 (cited in note 4).

${ }^{103}$ In re "Agent Orange" Product Liability Litigation, 611 F Supp 1452, 1461-62 (E D NY 1985), rev'd, 818 F2d 216 (2d Cir 1987).

${ }^{104}$ See, for example, Venegas v Mitchell, $110 \mathrm{~S} \mathrm{Ct} 1679$ (1990) (the Civil Rights Attorneys Fees Awards Act, 42 USC $\$ 1988$ (1982), which provides authority to the court to award a "reasonable" attorneys fee, does not invalidate a contigency fee agreement between a plaintiff and an attorney under which the attorney's compensation exceeds the statutory award).
} 
sion in future cases will be to induce plaintiffs' consortia either to exaggerate the investor-attorneys' hours or to assign these individuals work that others could perform more efficiently, in order to justify giving them extra compensation that the court can accept. ${ }^{168}$

Accordingly, judicial scrutiny of fee-sharing arrangements within the plaintiffs' consortium should be minimal. ${ }^{168}$ Unless there are exceptionally good reasons to upset such an arrangement, the trial court should accept it as written. ${ }^{167}$ Indeed, we would suggest that the fee-sharing arrangements among plaintiffs' counsel should be of no concern whatever to the court and, in the absence of unusual factors, should not even be disclosed. Agent Orange should not be followed in future cases.

Even if the Agent Orange case were to be dispatched to an unmarked grave, however, the problems with the lodestar calculation itself remain. Here, there are a number of possible mechanisms to reduce the uncertainty of the calculus. First, the fear of excessive fee requests in common fund cases might be handled by the appointment of a guardian ad litem to protect the absent class members or corporation. ${ }^{168}$ A guardianship would offer many of the same benefits - and pose many of the same problems-as a guardianship to protect absent parties in settlements, as discussed above. Guardians have been appointed in a few cases, although the practice appears to be uncommon. ${ }^{168}$

Existing .legal practice reflects several strategies for reducing the burden of fee calculations. The Supreme Court has warned that the fee determination should not become a collateral trial. ${ }^{\mathbf{1 7 0}}$ The message, apparently, is that the factfinder should not be as careful in fee determinations as it is in determining damages or other matters going to the merits of the litigation. And at least one

${ }^{18 s}$ For an earlier, and equally poorly reasoned, decision with the same general tenor as Agent Orange, see Lewis v Teleprompter Corp., 88 FRD 11, 17, 21-22, 24 (S D NY 1988) (rejecting 10 percent finder's fee to attorney for supplying named plaintiff, which had been freely agreed to by other attorneys).

${ }^{18 s}$ See Coffee, $54 \mathrm{U}$ Chi L Rev at 903 (cited in note 4) (advocating a "rule of judicial benign neglect" in such cases).

${ }_{167}$ This appears to be the rule in other jurisdictions. See, for example, Valente $v$ Pepsico, Inc., Fed Sec L Rptr (CCH) II 96,921, at 95,863 (D Del 1979); In re Ampicillin Antitrust Litigation, 81 FRD 395, 400 (D DC 1978).

${ }^{188}$ See A. Miller, Attorneys' Fees in Class Actions at 230-34 (cited in note 79); Newberg, Class Actions at CS13-9 (cited in note 54).

${ }^{168}$ For two cases in which the court did appoint a guardian, see Haas $v$ Pittsburgh National Bank, 77 FRD 382, 383 (W D Pa 1977); Miller v Mackey International, Inc., 70 FRD 533, 535 (S D Fla 1976).

${ }^{170}$ Hensley $v$ Eckerhart, 461 US 424, 437 (1983). 
judge has experimented with time-saving methods for determining a reasonable fee, such as sampling techniques into the reasonableness of the hours or the use of uniform blended hourly rates. ${ }^{111}$ Yet the use of second-class procedures for fee determinations, while it may reduce the burden on courts and litigants, simultaneously aggravates the already marked uncertainty in the fee calculation. There is no immediately obvious reason why the courts should give short shrift to fee calculations as compared with other judicial responsibilities. At issue in the fee calculation are legal rights no less important than other rights stemming from the disposition of the case on the merits or from the damages calculation.

One possible way of avoiding many of the problems associated with the calculation would be to increase the use of expert testimony at attorney fees hearings. Apart from the added cost, it is unclear why expert witnesses are rarely utilized in this context. ${ }^{172}$ An expert witness would more reliably determine the reasonable hourly fee than, for example, a judge who may rely on a few affidavits and memories of a law practice long-abandoned. Similarly, experts might be more capable than judges of assessing the reasonableness of hours expended-especially when the judge's past experience may have been in large firm practice with its very different patterns of supervision and control of litigation. Experts would provide useful information about the riskiness of the litigation ex ante. Of course, the contribution of an expert can vary depending on the witness's integrity, judgment, and knowledge. But regardless of the utility of expert witnesses generally, there is no reason to suppose that an expert witness would be any less useful in the attorneys' fee context than in many other litigation settings.

An alternative method for reducing the burden of fee calculations, with potentially less downside in terms of loss of factfinding reliability, would be for the trial court to appoint a special master for the purpose of assessing the fee. ${ }^{173}$ The master would have au-

${ }^{171}$ See Harman v Lyphomed, Inc., 734 F Supp 294, 298 (N D Ill 1990).

${ }^{172}$ But see, for example, Ramos v Lamm, 632 F Supp 376, 387 (D Colo 1986). For an unusual case in which the court appointed its own expert witness, see $M$. Berenson $C o$. $v$ Faneuil Hall Marketplace, Inc., 671 F Supp 819, 825 (D Mass 1987).

${ }^{173}$ The use of special masters is governed at the federal level by FRCP 53. Although appointment of a master is ordinarily "the exception and not the rule" even as to nonjury issues such as the calculation of attorneys' fees, FRCP 53(b), an appointment for assessing fees might be supported as involving a "matter of account" or as being analogous to a "diffcult computation of damages." Id. Alternatively, the court could encourage the interested parties to consent to the appointment of a master, in which case special justifications for the reference are not required. Id.

The use of special taxing masters is recommended, at least for larger courts, in the 
thority to require the production of evidence such as time sheets and could examine affidavits or take testimony. ${ }^{174}$ The master's findings would be controlling unless clearly erroneous ${ }^{175}$ and if stipulated to by the parties in advance would be final except as to matters of law. ${ }^{176}$ Although the special master's time would itself be costly, ${ }^{177}$ the costs could be justified if part of the burdensome factual inquiry could be passed to an individual whose time is presumably less valuable than that of a trial court judge. Special masters might prove particularly useful if individuals could be used on a repeat basis and thus developed expertise in fee calculations. Special masters with expertise in fee awards would resemble the taxing masters charged with awarding attorneys' fees in the United Kingdom. Although courts have not experimented extensively with special fee masters to date, ${ }^{178}$ the idea holds sufficient potential to warrant further study.

A special master would not resolve all the problems in the lodestar calculation, however. The hourly rate, hourly fee, and multiplier determinations would not necessarily be more certain if performed by a special master than by a judge, although a master might take more time on the task and, if appointed on a repeat basis, might possess somewhat greater expertise. Further, there are significant diseconomies in the use of masters, in that the reasonable hours and multiplier determinations depend heavily on the substance and history of the litigation. In jurisdictions (most prominently the federal courts) in which the judge typically oversees the litigation from the start, the judge would have a store of knowledge about the lawsuit that the master could not easily emulate. Referring the fee determination to a special master would also reduce the trial court's control over plaintiffs' attorneys, who would no longer fear retribution (or hope for reward) from the trial judge in the setting of fees.

Report of the Federal Courts Study Committee at 104-05 (cited in note 146). See also A. Miller, Attorney's Fees in Class Actions at 234-36 (cited in note 79) (use of masters on fee issues is "probably a useful and efficient step").

276 FRCP 53(c).

175 FRCP 53(e)(2).

178 FRCP 53(e)(4).

177 The costs would be paid out of the fund or by the parties as the court directs. See FRCP 53(a).

${ }^{178}$ But see In re Flight Transportation Corporation Securities Litigation, 685 F Supp 1092, 1094 (D Minn 1987) (in complex securities fraud litigation, court appointed a "Fee Review Committee" to audit the number of hours expended by each of 28 plaintiffs' firms and each firm's hourly rates; committee's efforts resulted in "substantial reductions in the original lodestar figure each firm had requested in their respective petitions"). 
b) Percentage method. The percentage method, although not perfect, is potentially a better way of calculating fees. As we have already noted, ${ }^{179}$ an alternative to the lodestar approach in common fund cases is to compensate the attorney with some fixed percentage of the recovery. If the lodestar resembles a standard hourly fee (albeit with significant differences), the percentage method resembles the ordinary contingent fee. Regardless of the merits of the case or the hours spent on the litigation, the plaintiffs' attorney under a percentage system receives a fixed proportion of the fund generated on the client's behalf.

The percentage method has several potential advantages over the lodestar method. ${ }^{180}$ First, and perhaps most importantly, it is easy to calculate: simply take the total award to the class or corporation, multiply it by the applicable percentage, and award that amount to the attorney. Compared to the arcane lodestar calculation, the advantages of the percentage approach are nearly selfevident. Similarly, the percentage method offers a bright-line rule and establishes reasonable expectations on the part of plaintiffs' attorneys as to their expected recovery. It thus provides some reduction in the risk of litigation, which might at the margin induce additional private enforcement of the law. And the percentage approach obviates the dangers that plaintiffs' attorneys will over-litigate cases where they have a high probability of success-especially cases where the defendant has essentially agreed to a settlement in advance of the work. For these and other reasons, a suitably designed percentage fee may be preferable to the currently dominant lodestar methodology. The recent mini-trend back to percentage fees ${ }^{181}$ is thus a potentially constructive development.

Nonetheless, the percentage method is also subject to serious deficiencies. First, as we have already demonstrated, ${ }^{182}$ the percentage method results in systematic excess profits for plaintiffs' attorneys-returns beyond what the attorney would earn in an efficiently functioning market. The reason is that attorneys will take only cases for which the ex ante returns are equal to or greater

170 See notes 66-72 and accompanying text.

180 Percentage fees are recommended for common fund cases in Court Awarded Attorney Fees: Report of the Third Circuit Task Force, 108 FRD 237, 255 (1985). The Federal Courts Study Committee advises "further study" of a percentage-of-the-recovery method in light of the "lodestar method's problems." Report of the Federal Courts Study Committee at 105 (cited in note 146).

181 See note 66 and accompanying text.

${ }^{182}$ See notes $68-70$ and accompanying text. 
than the opportunity costs of their time, and there is no market adjustment of the applicable compensation percentage to equilibrate supply and demand. Some of these excess returns would presumably be dissipated through the transactions costs of organizing larger plaintiffs' consortiums; others would be captured by plaintiffs' attorneys, especially those with sufficient influence at the plaintiff's' bar to obtain frequent appointments as lead counsel. In' either event, there is an element of welfare loss to society under the percentage system.

Second, the percentage method results in fewer cases being brought than would be brought in a well-functioning private market for-attorney services. The standard economic model of litigation predicts that plaintiffs will bring suit whenever their expected return from the litigation exceeds their expected costs. ${ }^{183}$ In traditional litigation settings, it would be rational for plaintiffs to sue even when, for example, their expected attorney fees represent a very high percentage of their expected recovery. The percentage method thus cuts off a large number of cases that the plaintiff would rationally prosecute in standard settings. For example, assume that in a jurisdiction with a 25-percent-of-the-recovery rule a given litigation is expected to generate a fund of $\$ 1,000,000$ with costs 'to the plaintiffs' attorney of bringing the litigation of $\$ 500,000$. This litigation would not be brought because the attorney expects fees of only $\$ 250,000$. If, on the other hand, the plaintiff were an invididual rather than a class or corporation under the control of hostile management, the litigation would be brought because it would generate an expected profit to the plaintiff of $\$ 500,000$.

It may seem perverse at first glance to encourage the prosecution of disputes where the transactions costs of obtaining relief are such a high percentage of the ultimate recovery. One might easily surmise that society would be better served if the defendant were allowed to keep the $\$ 1,000,000$, even if wrongfully obtained, on the theory that the defendant will put that sum to more socially beneficial uses than the drafting of briefs or the analysis and storage of millions of documents. On the other hand, there is no guarantee that this will be the case.

${ }^{183}$ For articulation of the standard model, see Posner, Economic Analysis of Law $\S 21.5$ at 522-28 (cited in note 8); John P. Gould, The Economics of Legal Conficts, $2 \mathrm{~J}$ Legal Stud 279 (1973); William M. Landes, An Economic Analysis of the Courts, 14 J L \& Econ 61 (1971); Richard A. Posner, An Economic Approach to Legal Procedure and Judicial Administration, 2 J Legal Stud 399 (1973). 
Moreover, litigation rules must be assessed in light of their probable effect on primary conduct. If defendants know that they can probably keep their wrongful gains, then more individuals will be induced to engage in socially undesirable actions. Thus, the social wealth effects of litigation with very high transactions costs are not easy to calculate even in theory. Meanwhile, the percentage method cuts off much litigation that would serve the economic interests of the putative clients. Such a rule may be necessary to protect against even larger wealth transfers from clients to attorneys, but the effect of cutting off bona fide claims seems at least a cause of legitimate concern about the social utility of the percentage method.

Although we prefer the percentage method to the lodestar calculation, it has several drawbacks. Accordingly, alternative arrangements-such as the auction procedure we describe in Part V of this Article-appear worthy of serious consideration and experimentation.

\section{Regulation of the Named Plaintiff}

So far we have discussed the allocation of litigation authority among various interested parties. Now we address the regulations restricting the powers and qualifications of one of those parties, the named plaintiff. We focus on this topic because the status of this named plaintiff presents the conflict between the reality of class and derivative litigation and the traditional image of litigation in the starkest possible light. The general thrust of the regulatory system as applied to named plaintiffs has been to treat these individuals as if they are not significantly different from plaintiffs in ordinary litigation. We conclude that named plaintiffs are-or should be-largely irrelevant in large-scale, small-claim cases and should be eliminated. Plaintiffs' attorneys should be allowed to file "Jane Doe" or "Richard Roe" complaints on behalf of unnamed, absent class members or shareholders.

The regulations governing the persons who are allowed to be named or representative plaintiffs in class and derivative litigation arise under four different sources of legal rules: the Federal Rules of Civil Procedure (and analogous state procedural codes), the codes of professional responsibility, Article III of the Constitution, and the due process clause. From a functional point of view, however, the regulation of named plaintiffs can be described by two general rules: first, that the claim of the named plaintiff must be typical of the claims of absent class members or other sharehold- 
ers; and second, that the named plaintiff must be capable of providing adequate representation of the class or corporation.

There is some conceptual and factual overlap between the typicality and adequacy requirements. In theory, they serve the common purpose of protecting absent class members or shareholders. Although Rule 23 lists them as separate and independent requirements that the named plaintiff must satisfy, ${ }^{184}$ typicality and adequacy are sometimes conflated in a general and amorphous inquiry into the adequacy of representation. ${ }^{185}$ Some courts and commentators have argued that the concepts do not have independent meaning, at least as applied in the administration of Rule $23 .^{186}$ Yet the requirements are conceptually distinct: ${ }^{187}$ typicality refers to the nature of the representative plaintiff's interest in the litigation and requires a relatively close fit between the representative plaintiff's interest and the interest of absent parties; ${ }^{188}$ adequacy refers to the ability and willingness of the named plaintiff to act as a competent champion of the class or corporation in the lawsuit.

We will criticize both the typicality and adequacy requirements as presently administered in large-scale, small-claim class action and derivative suits. The requirements are often in conflict with one another. A plaintiff whose claim is typical of the other class members or shareholders will often not be able to represent those absent plaintiffs adequately, and a plaintiff who can provide

384 See FRCP 23(a)(3), (a)(4). FRCP 23.1, governing derivative litigation, states that an action shall" not be maintained "if it appears that the plaintiff does not fairly and adequately represent the interests of the shareholders . . . " There is no analogous typicality requirement in Rule 23.1 itself, but courts insist on typicality in applying the requirement in Rule 23.1 that the named plaintiff "fairly and adequately" represent the shareholders. See, for example, Davis v Comed, Inc., 619 F2d 588, 597-98 (6th Cir 1980) (named plaintiff in derivative suit challenging sale of corporate property was not a proper representative because he wanted to acquire the property in question for himself); Baron $v$ Strawbridge \& Clothier, 646 F Supp 690, 695 (E D Pa 1986) (named plaintiff involved in attempted hostile takeover of corporation was not a proper representative). In addition, as we discuss at notes 223-28 and accompanying text, derivative plaintiffs must ordinarily establish that they were shareholders at the time of the alleged wrong to the corporation; this is evidently a partial typicality requirement.

${ }^{185}$ See, for example, Schatzman v Talley, 91 FRD 270, 273 (N D Ga 1981); James W. Moore and John E. Kennedy, 3B Federal Practice if 23.06-2 at 23-169 (Matthew Bender, 2d ed 1987).

${ }^{188}$ See, for example, Comment, Class Actions, Typicality, and Rule 10b-5: Will the Typical Representative Please Stand Up?, 36 Emory L J 649, 652 (1987); Comment, Federal Rule of Civil Procedure 23(a)(3) Typicality Requirement: The Superfluous Prerequisite to Maintaining a Class Action, 42 Ohio St L J 797 (1981) (independent significance should not be given to the typicality requirement).

${ }^{187}$ See, for example, Herbert B. Newberg, 1 Class Actions $\S 3.13$ at 164-65 (McGrawHill, 2d ed 1985).

${ }^{188}$ See Benjamin Kaplan, Continuing Work of the Civil Committee: 1966 Amendments of the Federal Rules of Civil Procedure (I), 81 Harv L Rev 356, 387 n 120 (1967). 
adequate representation will often have a claim that is not strictly typical of the other class members or shareholders. Even when the typicality and adequacy requirements can be reconciled, they often fail to serve their intended purposes and frequently result in perverse outcomes. Accordingly, we call for comprehensive revision, and in some cases the elimination, of the regulations governing the representative or named plaintiff in class and derivative suits.

\section{A. General Defects of the Rules}

There are two general regulatory defects that apply in almost all typicality and adequacy settings. Because these are cross-cutting considerations, we analyze them before turning to more particular problems under the typicality and adequacy rules.

\section{Enforcement by defendants.}

The enforcement responsibility for the typicality and adequacy rules lies principally with the defendant, an actor with incentives that are often diametrically opposed to those of the client whose interests are supposedly being protected. The defendant has little interest in ensuring that the representative plaintiff's claims typify the claims of the class or corporation, or that the representative plaintiff acts to ensure that the corporation or absent class members will be adequately represented. ${ }^{189}$ Indeed, the only situation in which the defendant could be expected to act as a faithful champion of the plaintiffs' interests on the issues of typicality and adequacy is when the party seeking representative status seeks to act in a way that would harm both the defendant and the other class members or shareholders. For example, if the representative plaintiff actually intends the litigation to force management to agree to a merger that is unfair to a corporation's shareholders, the defendant management and the company's shareholders will share an interest in cutting off the litigation. It seems safe to say, however, that cases in which the defendant and the class or corporation share a common interest adverse to the interests of the party seeking representative status will be quite rare.

\footnotetext{
189 See Sanderson $v$ Wirner, 507 F2d 477, 480 (10th Cir 1974); Umbriac v American Snacks, Inc., $388 \mathrm{~F}$ Supp 265, 275 (E D Pa 1975) ("defendants, who naturally have no interest in the successful prosecution of the class suit against them, are called upon to interpose arguments in opposition to class determinations verbally grounded upon a concern for the 'best' representation for the class while the implicit, but nonetheless real, objective of their vigorous legal assaults is to insure 'no' representation for the class").
} 
In the more frequent cases where the defendant's interests are not aligned with those of the class or corporation, the defendant cannot be expected to serve the class or corporation's interests when challenging the typicality or adequacy of representation..$^{\mathbf{1 9 0}}$ Instead, the defendant is likely to act strategically to serve its own interests and harm those of the class. ${ }^{101}$ First, the defendant may attempt to use the typicality and adequacy rules as a means for influencing the choice of plaintiffs' counsel. The defendant is unlikely to challenge the named plaintiff's typicality or adequacy, even when such a challenge might be successful, if the defendant believes that counsel representing this particular individual is someone who is likely to cut a favorable deal in settlement. On the other hand, the defendant may challenge typicality or adequacy, even when such a challenge is likely to fail, if the defendant believes counsel for the representative plaintiff to be vigorous and tough-minded in settlement negotiations, or if the defendant believes that the representative plaintiff is indeed likely to act as an effective monitor of the plaintiffs' attorney. ${ }^{192}$

The defendant's role in enforcement could generate the perverse result of actually reducing the level of typicality and adequacy of representation below what would otherwise exist. For example, the defendant is unlikely to challenge typicality when the plaintiff's claims are in fact atypical. The defendant may sometimes benefit if the named plaintiff has interests in the litigation that are not shared by the class as a whole, because the defendant may find a means for settling the case cheaply on terms that favor the named plaintiff over the other class members or shareholders. Conversely, the truly typical named plaintiff is one whose claims are indistinguishable from the claims of other class members or shareholders; such an individual is likely to be deterred from act-

${ }^{180}$ See Eggleston $v$ Chicago Journeymen Plumbers' Local Union, 657 F2d 890, 895 (7th Cir 1981) (allowing defendant to police the class representative's adequacy is like "permitting a fox .... to take charge of the chicken house").

${ }_{191}$ See Susan Getzendanner, Class Certification Discovery, 15 Litigation 25 (Fall 1988) ("As defense counsel in a certification war, you want global, all-out class discovery even if there is only a modest chance of defeating certification... [ [O]ften, you can knock out the class representative. In that case, the battle may go ahead, but the plaintiffs will not have their chosen standard bearer."). For a nice example of an all-out attack on the representative plaintiffs, see In re Consumers Power Co. Securities Litigation, 105 FRD 583, $602-07$ (E D Mich 1985) (various named plaintiffs challenged on grounds that they were too closely related to the class attorney, too old, too sick, too different from the typical class member, too incompetent, too busy, too dishonest, and too much under someone else's influence).

${ }^{182}$ Although often overlooked, this problem has been understood for many years. See Zechariah Chaffee, Jr., Some Problems of Equity 237-38 (Mich Law School Press, 1950) ("It is a strange situation where one side picks out the generals for the enemy's army."). 
ing as a representative plaintiff in the first place if she fears being grilled in a deposition as to the nature of her interest in the litigation, ${ }^{193}$ especially if she has nothing to gain from the litigation other than her pro rata share of the recovery. ${ }^{194}$ Plaintiffs who are willing to endure the rigors of a deposition as to their typicality are, virtually by that fact alone, not typical.

By the same token, defendants often have little incentive to challenge the adequacy of named plaintiffs who in fact are inadequate representatives of the class or corporation. Other things being equal, the quality of representation of the class or corporation will be lower with an inadequate representative plaintiff than with an adequate one. Because defendants are in an adversary relationship with the class or corporate plaintiff, they can be expected to be pleased when the named plaintiff is an inadequate representative. Certainly they are not going to bring this matter to the attention of the court with a request that the named plaintiff be replaced, at least not unless they believe that they can gain some strategic benefit from doing so.

${ }^{10 s}$ One former federal judge observes that defense counsel depose named plaintiffs as often and as vigorously as possible "because such inquiries can apply intense pressure on the plaintiffs. The more uncomfortable the named plaintiffs become, the less interest they may have in a suit where their own recoveries are likely to be modest." Getzendanner, 15 Litigation at 26 (cited in note 191). See also Cooper and Kirkham, 7 Litigation at 35-36 (cited in note 139). For cases in which the named plaintiff was evidently subject to such a grilling, see Weinstein v American Biomaterials Corp., 123 FRD 442, 445 (S D NY 1988) (transcript of named plaintiff's deposition came to 170 pages); Goldwater $v$ Alston \& Bird, 116 FRD 342, 353 \& n 40 (S D Ill 1987) (deposition of named plaintiff by "at least a half dozen highly experienced, antagonistic attorneys" took three days and resulted in a 600 page transcript).

194 Plaintiffs' attorneys undoubtedly provide some kind of payment to the representative plaintiffs in some cases to compensate them for their services. There is no way to measure the prevalence of this practice, as it is almost never publicly disclosed. Recently, however, several courts have awarded bonuses or other extra compensation to named plaintiffs to compensate them for their services to the class or corporation, a development we view as salutary because it tends to reduce the de facto dominance of the established firms. See, for example, In re Dun \& Bradstreet Credit Services Customer Litigation, 130 FRD 366, 374 (S D Ohio 1990) (two named plaintiffs received bonuses of $\$ 55,000$, and three others $\$ 35,000$ each); In re First Jersey Securities, Inc. Securities Litigation, 12 Class Action Rep 536 (E $\mathrm{D} \mathrm{Pa} 1989$ ) (\$25,000 bonus for named plaintiff); Fossett Corp. $v$ Gearhart, 12 Class Action Rep 470 (N D Tex 1989) ( $\$ 10,000$ bonuses for each of two named plaintiffs). But see Weseley $v$ Spear, Leeds \& Kellogg, Fed Secur L Rptr (CCH) १ 94,403 at 92,616 (E D NY 1989) (denying requested $\$ 5,000$ bonus for named plaintiff on ground that if named plaintiffs expected bonuses they might be "tempted to accept suboptimal settlements").

If the rules on large-scale, small-claim class and derivative litigation were reformed as we suggest, however, to eliminate the requirement of an actual named plaintiff, see notes 219, 248-49 and accompanying text, it would not be necessary to compensate named plaintiffs at all. 
Although a weak mechanism, enforcement by defendants might be justifiable as the only feasible regulatory approach, if it were not for the fact that the court itself is much better situated to enforce these requirements. The court is not subject to the egregious built-in conflict of interest that impeaches enforcement by defendants. To be sure, courts already have power, in theory, to enforce the typicality and adequacy requirements. In practice, however, the courts tend to play a passive role, focusing on questions of typicality and adequacy only when they are specifically raised by defendants. As long as defendants retain the primary role in enforcement, courts are unlikely to provide adequate protection to absent class members or corporate shareholders.

As a general matter, therefore, it appears sensible to redesign the regulatory structure in order to reduce or eliminate the defendant's role in "protecting" the plaintiffs' interests. Instead, as discussed below, the role of the courts in this area should be expanded.

2. Reduction in the supply of representative plaintiffs.

A second major cross-cutting problem with the typicality and adequacy rules is that they exclude a substantial number of individuals from the pool of potential class or derivative plaintiffs. This weeding out of potential plaintiffs has three negative effects: it increases the transactions costs of litigation, it reduces the supply of attorneys able to perform legal services for the class or corporation, and it destroys the viability of a class of lawsuits that would be brought if the aggrieved person were an individual rather than a group or a corporation under hostile management.

Consider first the problem of transactions costs. Representative plaintiffs do not seek out attorneys to represent them in class action or derivative litigation. The attorney usually finds the plaintiff. ${ }^{185}$ The inevitable consequence is an increase in the costs to attorneys of obtaining a suitable plaintiff. The attorney must search harder for plaintiffs when suits arise, must spend more time maintaining contacts with potential sources of plaintiffs, and must work harder at convincing potential representatives to agree to act on behalf of the class or corporation. Many of these costs represent deadweight social losses that should be avoided if possible. ${ }^{196}$ Fur-

195 See Coffee, 86 Colum L Rev at 681 (cited in note 4).

${ }^{108}$ In the case of the typicality requirement, the problem of increased transactions costs is especially prominent in the derivative litigation context. The attorney must conduct a search in each case for some unrelated party who happens to have held stock at the time of 
ther, the typicality and adequacy requirements increase transactions costs by providing opportunities for discovery as well as fertile breeding grounds for legal disputes that require the attention of judges and attorneys alike.

A second defect of strict typicality and adequacy rules is that insofar as they reduce the supply of representative plaintiffs, they also reduce the supply of attorneys willing and able to bring class and derivative litigation. If the attorney wishes to enter this business, she must have a reliable source of plaintiffs. Attorneys who lack such a reliable source cannot participate even though they may be fully competent and willing to do so. The typicality and adequacy rules therefore create a barrier to entry into the plaintiffs' bar, reducing competition from new entrants and enhancing the stature and influence of the established firms in the market. This phenomenon appears to be particularly pronounced in the case of securities fraud litigation, where some of the larger firms probably maintain extensive contacts with private investors and securities brokers willing to act as or to identify plaintiffs. ${ }^{197}$

In most markets, the elimination of potential competition and the creation of barriers to entry would appear per se undesirable.

the alleged wrong, and must then convince the party to act as derivative plaintiff. The costs of such a search will often be significant. See notes 226-28 and accompanying text.

The principal costs of the adequacy requirement are felt in the class action area. This is so because of the the rule in many states that the representative plaintiff must bear the costs of class notice in the event the class is certified but the litigation proves unsuccessful. Because notice costs can run upwards of $\$ 1,000,000$, few class representatives-in fact, probably none other than the attorney herself-would willingly shoulder this burden. Although in reality a majority of courts have allowed plaintiffs to circumvent the requirement to a significant degree, financial adequacy raises the attorney's search costs because the attorney must find a plaintiff with at least the appearance of a highly solid financial footing.

197 The largest plaintiffs' securities firm is Milberg Weiss Bershad Specthrie \& Lerach of New York. Other major players in this field are Abbey \& Ellis (New York); Stull, Stull and Brody (New York); Berger \& Montague (Philadelphia); Much, Shelist, Freed, Denbenberg, Ament \& Eiger (Chicago); and Wolf, Popper, Ross, Wolf \& Jones (New York). (Based on personal conversations with attorneys in the area.)

A good recent example of how these firms spar for control of securities class action litigation, with an unusual outcome, is In re Oracle Securities Litigation, 131 FRD 688, 69091 (N D Cal 1990). Within a week after the defendant corporation announced disappointing earnings, 14 class action complaints were filed against the corporation by more than 25 of the leading plaintiffs' securities firms in the country. Almost immediately Berger \& Montague and Milberg, Weiss called an organizational meeting for all other plaintiffs' firms. Fifteen firms attended and elected Berger \& Montague and Milberg Weiss as co-lead counsel. Two firms that had boycotted the organizational meeting challenged the motion to designate Berger \& Montague and Milberg Weiss as lead counsel. The result was an old-fashioned shootout in which the competing teams lavished praise on themselves and denigrated their adversaries. When the court insisted that they resolve their dispute by competitive bidding, the combatants quickly gained an appreciation of their opponents' qualifications and filed a joint petition for designation as lead counsel. 
The market for plaintiffs' attorneys, however, is somewhat unusual. Because fees are set by courts, rather than markets, and awarded on either a lodestar or percentage basis, the addition of new competition would not necessarily drive down the price of the service. Nevertheless, there remain good reasons to be concerned about the concentration of the market for plaintiffs' attorneys, especially in the securities fraud context. If entry into this market were less costly, the influence of repeat-player attorneys at the plaintiffs' bar would presumably be reduced. New entrants might find themselves increasingly able to gain stature and prestige among their colleagues-and therefore better situated to reap the economic benefits of lead counsel or steering committee appointments-by virtue of their legal skills and dedication. Thus a reduction of barriers to entry might well increase the level of quality competition among plaintiffs' attorneys, presumably to the benefit of both clients and the litigation system.198 Further, the entry of new counsel would likely enhance the monitoring of lead counsel by others in the plaintiffs' group, thus reducing agency costs. These advantages are significantly undermined if the typicality and adequacy requirements are administered with excessive stringency.

It should be evident that if the supply of available plaintiffs is reduced by strict typicality and adequacy requirements, at the margin certain cases will not be brought. Opponents of class action and derivative litigation may argue that this is a beneficial result, given the social disutility of this sort of litigation. As explained above, an analysis of the costs and benefits of class and derivative litigation within the overall economic system is outside the scope of this study. ${ }^{198} \mathrm{We}$ operate on the premise that because the relevant political authorities have determined to create class and derivative procedures, there is good reason to suppose that these mechanisms ought to be available to enforce violations of the law. If there are problems with this type of litigation, it would be far more appropriate to address them directly rather than policing them indirectly through a series of inexact and conceptually flawed proxies such as the typicality and adequacy requirements.

\footnotetext{
${ }^{198}$ In other words, if plaintiffs' attorneys did not compete on the basis of price, they would probably compete along other vectors, such as service.

199 See note 19.
} 


\section{B. Typicality}

We turn now to particular problem areas under the typicality requirement broadly defined. Questions of typicality arise in three principal settings: (1) cases in which class certification or derivative status is challenged on the ground that the representative plaintiff has interests that differ impermissibly from the interests of other class members or shareholders; (2) derivative lawsuits in which the representative plaintiff fails or arguably fails the requirement of contemporaneous ownership; and (3) cases in which the claims of the representative plaintiff, although initially sufficient to satisfy the typicality requirement, become atypical (or disappear) at some later point of the litigation. The issues presented by the typicality requirement implicate not only the applicable federal rules, but also principles of justiciability arising (in part) under Article III of the Constitution, and concerns for fairness to absent parties arising under the due process clauses of the Fifth and Fourteenth Amendments.

\section{Obtaining class or derivative status.}

Defendants in class action and shareholder's derivative litigation often challenge the representative plaintiff on the ground that her claim is not typical of the class or shareholders. The relief requested is usually an order denying class certification or striking the derivative allegations in the complaint. If the relief is granted, the action can proceed only as an individual action. In the context of derivative litigation, the action must be dismissed altogether if the claims of the representative plaintiff are derivative rather than direct.

This regulatory structure, in our view, is unsatisfactory, at least as applied to large-scale, small-claim cases. As presently administered, the rules fail to distinguish cases in which the identity of the plaintiff poses real dangers to the absent class members or corporation from cases in which this danger is illusory. Consider in this regard the run-of-the-mill typicality challenge in which the defendant complains that the named plaintiff enjoys an inappropriately close relationship with plaintiffs' counsel. The defendant may complain, for example, that the representative plaintiff is a mem- 
ber $^{200}$ or employee ${ }^{201}$ of counsel's law firm, a family member ${ }^{202}$ or close business associate ${ }^{203}$ of the class counsel, or an individual who, although not formally tied to class counsel, has a longstanding relationship and willingness to act as representative plaintiff. ${ }^{204}$ Occasionally the attorney herself seeks to act as representative plaintiff. ${ }^{205}$ Courts often accept these challenges and reject the named plaintiff as atypical.

Close connections between class representative and class counsel are alleged to create two principal dangers to the putative client. First, the representative plaintiff is likely to act as a poor monitor of plaintiffs' counsel if there is an overly close relationship between them. ${ }^{206}$ Thus, the representative plaintiff is unlikely to check the tendency of plaintiffs' counsel to favor her own interests over those of the class or corporation in key matters such as settlement. Second, under the law of jurisdictions, the representative plaintiff is liable to pay the costs of the litigation if the case is unsuccessful. ${ }^{207}$ The representative plaintiff is therefore likely to be more risk-averse than other class members or shareholders with respect to the outcome of the litigation, and may prefer the certainty of settlement-even at a relatively low amount-over the uncertain prospect of going to trial, even if the expected value of the trial outcome exceeds the settlement value. A representative plaintiff who is closely connected to the plaintiffs' attorney may

${ }^{200}$ See, for example, Susman v Lincoln American Corp., 561 F2d 86, 94 (7th Cir 1977); Turoff v May Co., 531 F2d 1357, 1360 (6th Cir 1976); In re AM International, Inc. Securities Litigation, 108 FRD 190, 197-98 (S D NY 1985); Stull v Baker, Fed Sec L Rptr (CCH) I 94,227 at 94,929 (S D NY 1973).

${ }^{201}$ See, for example, Shroder v Suburban Coastal Corp., 729 F2d 1371, 1375 (11th Cir 1984) (representative plaintiff primarily employed by class counsel's firm); Wellman $v$ Dickinson, 79 FRD 341 (S D NY 1978) (representative plaintiff was once associate in class counsel's firm).

${ }^{202}$ See, for example, Turoff, 531 F2d at 1360 (6th Cir 1976) (wife); Zlotnick v TIE Communications, Inc., 123 FRD 189, 193 (E D Pa 1988) (father); AM International, 108 FRD at 197-98 (brother); In re Consumers Power Co. Securities Litigation, 105 FRD 583, 602 (E D Mich 1985) (father-in-law).

${ }^{203}$ See, for example, Grossman v Waste Management, Inc., 100 FRD 781, 790 (N D Ill 1984) (named plaintiff had past fee-sharing relationships with class counsel); Flamm $v$ Eberstadt, 72 FRD 187, 190 (N D III 1976), aff'd as Susman, 561 F2d 86 (court took notice that plaintiffs' attorney had prior buisiness dealings with a named plaintiff).

204 See, for example, Katz v Comdisco, Inc., 117 FRD 403, 410 (N D III 1987) (plaintiff had previously acted as representative plaintiff in 16 class actions with plaintiffs' attorney); Kirby $v$ Cullinet Software, Inc., 116 FRD 303, 310 (D Mass 1987).

${ }_{208}$ See, for example, Bachman v Pertschuk, 437 F Supp 973, 974 (D DC 1977); Holland $\checkmark$ Goodyear Tire \& Rubber Co., 75 FRD 743, 745 (N D Ohio 1975); Shields v Valley National Bank, 56 FRD 448, 449 (D Ariz 1971).

${ }^{208}$ See, for example, Kirby, 116 FRD at 309 (named plaintiff who was father of attorney "could be unduly influenced by the possible benefit his son receives in attorneys fees, even if father does not financially benefit from the fees himself").

${ }^{207}$ See notes 253-55 and accompanying text. 
exercise undue influence on the attorney to induce her to settle for an inappropriately low figure. ${ }^{208}$

These supposed dangers, however, should not cause particular concern, at least in the case of large-scale, small-claim class action or derivative lawsuits. In such cases, the notion that the representative plaintiff exercises any significant leverage over the plaintiffs' attorney is dubious at best. The plaintiffs' attorney dominates the litigation regardless of whether the representative plaintiff is a complete stranger or the attorney's brother-in-law. The second argument-that the client would prefer settlement to avoid litigation costs-is even more unlikely. As we observe below, representative plaintiffs never actually pay litigation costs; it is a patent fiction to claim otherwise. The attorney pays the costs, and it is the attorney's incentives that control the outcome. To be sure, the potential liability for costs may cause the attorney to be risk-averse; but this will be true whether or not the representative plaintiff has some close relationship with the attorney. Accordingly, in large-scale, small-claim lawsuits, the relationship between plaintiffs' counsel and the representative plaintiff should make no difference whatever in the protection of class members or shareholders.

When the attorney herself attempts to act as class representative, courts may reject the representation on the ground that there is too great a danger the attorney will become a witness in the case. ${ }^{209}$ This consideration, however, should not be disqualifying. There is ordinarily no bona fide reason why the class representative should become a witness in large-scale, small-claim litigation. (Class members are often deposed under the existing system, but only for information as to their adequacy and typicality and not as to their knowledge of the facts underlying the issues in the case.) The class representative is a figurehead, and her testimony is-or should be-irrelevant to the factfinding process. Thus, even if the problems of an attorney acting as witness would require disqualification in traditional litigation, ${ }^{210}$ a different rule should apply in the unique context of large-scale, small-claim litigation.

Nearly identical considerations arise when the alleged lack of typicality stems, not from a preexisting relationship between named plaintiff and plaintiffs' counsel, but rather from some special sophistication or financial qualification of the representative.

\footnotetext{
${ }^{208}$ See Note, 84 Mich L Rev at 313 (cited in note 131) (named plaintiff has an incentive to settle in order to avoid liability for expenses if the case is unsuccessful at trial).

${ }^{209}$ See, for example, Susman, 561 F2d at 91; Kriger v European Health Spa, Inc., 56 FRD 104, 105 (E D Wis 1972).

${ }^{110}$ See Model Code DR 5-102; Model Rule 3.7.
} 
In securities fraud litigation, for example, defendants have argued successfully that a sophisticated investor could not be a representative plaintiff because the individual's financial acumen made it unlikely that she would be misled by the alleged misrepresentations or omissions. ${ }^{211}$ But it is difficult to justify such a result on the basis of any alleged dangers to the class or corporation from having a financially sophisticated representative. Excluding such investors as representative plaintiffs, on the other hand, is likely to harm the interests of the class members or the corporation. After all, only a financially sophisticated investor is likely to recognize the statements that might give rise to liability under the securities laws. Sophisticated investors are much less easily deterred from acting as representative plaintiffs by the threat of depositions. If such investors, are not permitted to act as representative plaintiffs, the litigation may not go forward at all, or if it does, the class members or shareholders may be less well-represented by their attorneys than if sophisticated investors were routinely permitted to act as class representatives.

The sophisticated investor cases are a subclass of a broader category of cases in which the typicality of the representative plaintiff is challenged on the ground that she is subject to defenses not available against the class as a whole. ${ }^{212}$ In general, we believe that the courts err when they dismiss large-scale, small-claim class actions on the ground of unique defenses, so long as the representative plaintiff is indeed a figurehead and not an individual exercising any real control over the litigation. If the representative plaintiff is a figurehead, the existence of special defenses should be completely irrelevant because the attorney is extremely unlikely to alter the representation to the detriment of other class members in this case. If, on the other hand, the representative plaintiff is not a figurehead, but rather exercises, or could exercise, substantial influence over the attorney, the courts would do well to make a more

${ }^{211}$ See, for example, Irvin E. Schermer Trust $v$ Sun Equities Corp., 116 FRD 332, 337 (D Minn 1987) (named plaintiffs were too sophisticated because one was a former prosecutor and a securities fraud attorney and the other a law firm founder who had managed a complex securities portfolio); Zandman $v$ Joseph, 102 FRD 924, 930-31 (N D Ind 1984) (sophisticated investor who did not rely on market in making trades was not a typical plaintiff in fraud-on-the-market case). But see Kennedy $v$ Tallant, 710 F2d 711, 717 (11th Cir 1983) ("The degree of investment experience of sophistication of each of the class members is irrelevant."); Feder v Harrington, 52 FRD 178, 182 (S D NY 1970) (same).

${ }_{212}$ See, for example, Gary Plastic Packaging Corp. v Merrill Lynch, Pierce, Fenner \& Smith, Inc., 903 F2d 176, 180 (2d Cir 1990); Warren v Reserve Fund, Inc.; 728 F2d 741, 747 (5th Cir 1984); J.H. Cohn \& Co. v American Appraisal Associates, Inc., 628 F2d 994, 998-99 (7th Cir 1980). 
discriminating inquiry into the ways in which individualized defenses might affect the representation of the class as a whole. ${ }^{213}$ Rejection of the named plaintiff would not be necessary even in this setting if the defenses were so separate from the underlying determination of liability that representation of the named plaintiff would not substantially threaten the interests of other class members. However, the trial court should have discretion to disqualify a named plaintiff if zealous representation on the named plaintiff's special defense could impair the interests of the class in obtaining as large a recovery as possible. These matters can only be evaluated by the trial court on a case-by-case basis.

In other cases named plaintiffs have been rejected because their claims were so large that the court determined that they were able to pursue the litigation as an individual rather than as a class action. ${ }^{214}$ It is difficult to understand what benefit is conferred on the absent class members by excluding representative plaintiffs with relatively large claims. Such individuals would presumably be the most motivated to bring the litigation in the first place because they have the most at stake. If they are excluded, the chance that the action will be brought at all is reduced because plaintiffs' counsel must then search for a substitute representative. Excluding large-stake class representatives appears perversely calculated to eliminate whatever monitoring of the plaintiffs' attorney's actions might be feasible in the class action and derivative setting; largestake plaintiffs may have sufficiently large interest in the litigation to warrant active supervision of the attorney. Similarly, if large stakeholders are excluded from representation, they will have less incentive to monitor the conduct of potential defendants initially, thus potentially increasing the incidence of socially undesirable conduct. Other things being equal, therefore, sophistication or disproportionate stakes should not support disqualifying named plaintiffs on typicality grounds.

21 Whether the named plaintiff is situated to control the litigation can be evaluated on the basis of objective factors, such as the size of the named plaintiff's claim or other indications of the named plaintiff's personal interest in the litigation or relation with the attorney. Compare Kirby, 116 FRD at 310 ("In cases where a familial relationship with counsel raises questions about the adequacy of the plaintiff, the degree of concern and involvement demonstrated by the representative becomes especially important.").

214 See, for example, Stoudt v E.F. Hutton \& Co., Inc., 121 FRD 36, 38 (S D NY 1988) (rejecting representative status for plaintiff who sought more than $\$ 60,000$ in damages, with the observation that "[Rule 23] was not designed to permit large claimants, who are fully capable of proceeding on their own, to strengthen their bargaining position by threatening their adversaries with the prospect of class-wide relief and large attorney fee awards"); Steinmetz v Bache \& Co., Inc., 71 FRD 202, 205-06 (S D NY 1976). 
Defendants may also seek to disqualify the named plaintiff on the ground that she is a "professional" litigant in class or derivative suits. The existence of such professional plaintiffs is a matter of common knowledge. For example, one plaintiff, Harry Lewis, has been a named representative in over one hundred cases. ${ }^{215} \mathrm{De}-$ fendants may attempt to obtain discovery showing that the named plaintiff has an extensive history of involvement in class action or derivative litigation. The goal is either to disqualify the named plaintiff, or perhaps more commonly, to cast the named plaintiff and plaintiffs' counsel in a negative light before the judge. ${ }^{216}$

Interestingly, courts have little difficulty upholding the representative status of such professional plaintiffs, apparently bowing in this case to the realities of class and derivative litigation. ${ }^{217}$ This clearly seems a correct result; there is no reason to suppose that the representation of the plaintiff class or corporation will be impaired in any way because the named plaintiff is a repeat player. However, we do note that allowing repeat players to act as representative plaintiffs further accentuates the already-great advantages that established plaintiffs' attorneys have over new entrants in this market. Professional plaintiffs are often in the "stables" of existing firms. While we have no difficulty with the rule allowing professional plaintiffs to act as class or shareholder representatives, it should be accompanied by other reforms that would open up the plaintiffs' market to new service providers.

A final class of problematic cases are those in which the named plaintiff is simply not a member of the class of persons on whose behalf suit is brought. The Supreme Court has held that the requisites for a class action under Rule 23 are not satisfied if the named plaintiff is not a member of the class. ${ }^{218} \mathrm{On}$ its face, this

${ }^{215}$ See Lewis $v$ Anderson, 453 A2d 474, $475 \mathrm{n} 1$ (Del Chanc 1982), aff'd, 477 A2d 1040 (Del 1984); Coffee, $54 \mathrm{U}$ Chi L Rev at $885 \mathrm{n} 17$ (cited in note 4); Deborah A. DeMott, Limiting Directors' Liability, 66 Wash U L Q 295 (1988).

${ }^{216}$ See Kaufmann $v$ Credithrift Financial, Inc., 465 NE2d 207, 210 (Ind App 1984) (although class representative's status as "professional plaintiff" would not be disqualifying, trial court allowed discovery of past involvement in class litigation on ground that answers might lead to discovery of relevant information).

217 See, for example, Koenig $v$ Benson, 117 FRD 330, 336 (E D NY 1987) (named plaintiff's "litigious nature" insufficient to deny certification); Steiner v Ideal Basic Industries, Inc., 127 FRD 192, 194-95 (D Colo 1987) (same plaintiff as in Koenig, who had filed fifteen to twenty lawsuits, was adequate, as was another plaintiff who had filed so many lawsuits that he could not remember how many were pending); Zandman $v$ Joseph, 102 FRD 924, 933 (N D Ind 1984).

${ }^{218}$ See General Telephone Co. of the Southwest v Falcon, 457 US 147, 157-61 (1982) (Mexican-American who claimed he was discriminated against in promotion decision could not represent class of Mexican-Americans who were not discriminated against in hiring deci- 
appears to be a reasonable construction of the Rule 23(a)(3) requirement that the claims of the representative party be typical of the claims of the class. From a functional and pragmatic perspective, however, it is not at all clear that the rule should be so rigidly interpreted, at least in the large-scale, small-claim context. Given that the named plaintiffs are usually figureheads, the requirement of typicality serves little purpose other than to deter litigation. It would seem quite consistent with the purposes of Rule 23 to allow "Jane Doe" or "Richard Roe" complaints on behalf of unnamed absent class members. In the large-scale, small-claim context, these individuals can be considered perfectly appropriate "representative parties" whose claims are no doubt typical of the claims of the other absent class members. ${ }^{219}$

Where the named plaintiff's typicality is challenged on the ground that the group of persons of which the named plaintiff is a member has interests that conflict with the interests of others within the purported class, the courts play an important role in protecting the interests of absent class members against being inadequately represented by class counsel. ${ }^{220}$ For example, in Gilpin $v$ American Federation of State, County, and Municipal Employ$e e s,{ }^{221}$ a nonunion employee brought suit as class representative against a union and certain employers challenging a union agency fee paycheck deduction. The Seventh Circuit upheld the trial court's refusal to certify a class action, observing that the putative class was comprised of two different groups with potentially divergent aims: those who were hostile to unions in general on ideological grounds, and those who bore no particular animus toward unions but who wanted to free-ride for their representation services on the contributions of union members. Because the named plaintiffs were in the former category, they could not adequately represent all nonunion employees. Gilpin is only one of a number of cases in which courts appropriately either narrow or refuse to cer-

sion); East Texas Motor Freight System, Inc. v Rodriguez, 431 US 395, 463-64 (1977) (Mexican-American city drivers could not represent class of Mexican-Americans allegedly denied transfers to more desirable line-driver jobs when named plaintiffs were not qualified for line-driver positions).

210 We argue below that such complaints would also be consistent with the policies underlying doctrines of justiciability. See notes $248-49$ and accompanying text.

220 For an account of the problems with intra-class conflicts, see Garth, Conflict and Dissent in Class Actions: A Suggested Perspective, $77 \mathrm{Nw}$ U L Rev 492 (1982) (cited in note 98); Deborah L. Rhode, Class Conficts in Class Actions, 34 Stan L Rev 1183 (1982).

221875 F2d 1310-13 (7th Cir 1989). • 
tify a class on the ground that the representative plaintiff has interests that diverge from those of other class members. ${ }^{222}$

These cases, however, need not be conceived of as typicality cases per se. The underlying problem is not that the named plaintiff has interests that do not typify the interests of all class members. The divergence in interests between the named plaintiff and other class members is rather a function of a more fundamental problem, namely the divergence in interests among members of the class. Rather than focusing on typicality, which directs undue attention to the nature of the named plaintiff, courts should examine this more basic issue directly and ask whether the class itself is well-formed given the existence of divergent strains within it. If the conflicts of interest within the plaintiff class are significant, the court may narrow the class or split it into subclasses, as appropriate. But it can manage the litigation in this fashion without lengthy consideration of whether the named plaintiff's claim is typical of the absent class members. This observation underscores the need for reform of the procedural rules for class and derivative suits.

2. The contemporaneous ownership rule in derivative suits.

A second typicality rule is the so-called "contemporaneous ownership" requirement in derivative litigation. In general, to qualify as a representative plaintiff in a derivative suit, an individual must not only own stock at the time the suit is brought but must also have owned the stock at the time of the alleged wrong to

${ }^{222}$ See, for example, United Independent Flight Officers, Inc. $v$ United Air Lines, Inc., 756 F2d 1262, 1284 (7th Cir 1985) (upholding trial court's refusal to certify a class of airline pilots in suit challenging amendments to pension plan, on ground that differences among class members concerning their economic interests in the plan "represent a substantial conflict going to the subject matter of the litigation"); Phillips v Klassen, 502 F2d 362, 367 (DC Cir 1974) (upholding trial court's refusal to certify a class of postal employees challenging early retirement plan, observing that there were likely to be divergent views among class members as to whether the plan benefited or harmed them). Conflict between the named plaintiff and other class members can readily be determined if a high percentage of the class indicates opposition to the representation. See, for example, Bailey v Ryan Stevedoring Co., Inc., 528 F2d 551, 553 (5th Cir 1976) (204 of 230 class members rejected the class representative).

One interesting line of cases concerns class representatives who have a personal vendetta against the defendant. The general rule in such cases is that while "a plaintiff"s small personal animus is insufficient to render an otherwise qualified class representative inappropriate, an unduly antagonistic litigant, or a litigant who bears a grudge against the defendant is not an appropriate class representative." Kamerman v Ockap Corp., 112 FRD 195, 197 (S D NY 1986). This rule seems appropriate, at least when the named plaintiff's level of personal animus against the defendant, either alone or in combination with other factors, indicates that the named plaintiff is in a position to exercise substantial control over the plaintiffs' attorney. 
the corporation. ${ }^{223}$ This rule can only be justified as a typicality requirement; it tends to require that the interests of the representative plaintiff be aligned with those of the corporation during all relevant periods of the controversy.

The rationale for the contemporaneous ownership rule, however, appears questionable at best. No discernible harm to the corporation can arise simply from the fact that a given plaintiff may not have owned the stock at the time of the alleged harm. Such a plaintiff has the same interest after the fact as all other shareholders, including those who happen to have held their stock for a longer period. And since the representative plaintiff's principal role is to act as key to the courthouse door, there would appear to be little harm to the corporation even if some element of conflict could be established.

The most plausible current justification ${ }^{224}$ for the contemporaneous ownership rule would appear to be a concern with avoiding litigation that might harm the corporation, either because the litigation itself is not in the corporation's best interests, or because the possibility that such litigation would be brought will impose wealth-reducing costs on the corporation. These costs might occur in the form of higher insurance premiums or increased compensation for corporate officers to reimburse them for the risk of suit, for example. The greatest danger, according to this view, is the nonmeritorious "strike suit" brought by entrepreneurial attorneys solely for settlement value. The justification for the contemporaneous ownership rule, then, is that it deters strike suits by discouraging attorneys from purchasing shares themselves or causing someone they know to purchase shares in order to act as representative plaintiff-in other words, it discourages them from "manufacturing plaintiffs in order to initiate strike suit litigation."

${ }^{223}$ See FRCP 23.1(1). It seems odd that a contemporaneous ownership requirement for derivative suits arising under state law would be framed as a federal rule of civil procedure, since the plaintiff's right to bring suit would seem to be a matter of substance rather than procedure. See 28 USC $\$ 2072(b)$ (1983) (federal rules of civil procedure "shall not abridge, enlarge or modify any substantive right"); 28 USC \& 1652 (state laws provide rules of decision in federal litigation in cases where they apply). As a practical matter, however, the rules under state law appear similar. See, for example, Del Chanc Ct R 23.1.

${ }^{24}$ The original justification for the rule in federal courts was apparently a fear of collusive diversity jurisdiction. See Hawes v Oakland, 104 US 450, 452-53 (1882). This rationale is obviously inapplicable to state court jurisdiction, and appears to have little merit for federal court derivative litigation given that plaintiffs' attorneys can search for representative plaintiffs with suitable citizenship even under a contemporaneous ownership rule; the only difference is that the search costs will be higher. 
This argument, however, is not particularly plausible. Although a theoretical model exists in which suits are brought solely for their nuisance settlement value, ${ }^{225}$ the frequency of strike suits in derivative and class litigation remains an open question. Most observers agree that strike suit litigation is relatively uncommon. ${ }^{226}$ Defendants in class action and derivative litigation are typical repeat players, in that they are vulnerable to frequent lawsuits brought by entrepreneurial attorneys. It would not appear particularly desirable for such defendants (or their insurers, as the case may be) to settle cases for their nuisance value, because doing so would predictably establish a reputation as an easy mark and thus generate even more frivolous litigation. Conversely, a defendant that vigorously contests derivative or class action litigation, even when meritorious, is likely to gain a reputation as a party that derivative attorneys take on at their peril. Moreover; a plaintiffs' attorney who brings a strike suit incurs substantial risk; she must fund and staff the litigation subject to a high probability of nonsuccess at the end. The true strike suit, where it occurs, is unlikely to be overly costly for defendants because the plaintiff would be likely to settle at a very low figure.

To the extent that the strike suit is a problem in derivative cases, the contemporaneous ownership rule appears to be a poorly designed regulatory tool for handling the difficulty. It is overinclusive: bona fide derivative suits may be deterred if the plaintiffs' attorney must identify a contemporaneous shareholder. It is also underinclusive: to the extent strike suits are possible, the contemporaneous ownership rule does not prevent them. A plaintiffs' attorney wishing to engage in a strike suit simply has to expend additional resources to identify a contemporaneous shareholder. These additional expenses might deter some strike suits, but so would any other means for increasing the costs of class and derivative litigation. If the goal is to increase costs, it would seem more efficient to impose some sort of direct tax on the plaintiffs' attorneys, ${ }^{227}$ because doing so avoids the socially inefficient transactions costs of searching for an appropriate representative plaintiff.

${ }^{228}$ D. Rosenberg and S. Shavell, A Model in Which Suits are Brought for Their Nuisance Value, 5 Intl Rev L \& Econ 3 (1985).

${ }^{228}$ See, for example, Note, The Rule 23(b)(3) Class Action: An Empirical Study, 62 Georgetown L J 1123, 1136-37 (1974); Newberg, 3 Class Actions $\S 15.29$ at 246 (cited in note 187).

${ }^{227}$ Indeed, in some states a de facto tax may be applied to class and derivative litigation in the form of statutes providing that the plaintiff may be required to post a bond if her financial stake in the corporation is below some minimum threshold. As of 1988 such statutes were in effect in 14 states. Lewis D. Solomon, Donald E. Schwartz, and Jeffrey D. Bauman, Corporations: Law and Policy 892 (West, 2d ed 1988). Even where they are in effect the statutes play little current role in contemporary litigation. See Note, Security for 
Further, if the goal is to deter frivolous litigation, the most direct approach would be to sanction litigation when it is frivolous. Sanctions are now widely available under Rule 11 of the Federal Rules of Civil Procedure, which allows the trial court to fine attorneys who file pleadings that are not well-grounded in law or fact. ${ }^{228}$ Although not without problems of its own, Rule 11 appears to provide a potentially more carefully tailored regulatory response to the problem of frivolous litigation or strike suits than does the blunt instrument of the contemporaneous ownership rule.

The principal effect of the contemporaneous ownership rule, like that of the typicality rules discussed earlier, is to place artificial restrictions on the availability of plaintiffs' counsel. Plaintiffs' counsel with good access to potential plaintiffs are benefited disproportionately, and thus enhance their position of power and influence within the plaintiffs' bar. As in the case of the general typicality rules, the putative "client" is the loser.

\section{Justiciability considerations.}

Typicality rules also have a constitutional dimension. A named plaintiff whose claim does not represent the claims of the class may not have the power to invoke the jurisdiction of a federal court. If the named plaintiff has not suffered the type of harm alleged in the complaint, she may not be able to establish a "case or controversy" as required under Article III. ${ }^{229}$ Alternatively, the court might determine for prudential reasons not to adjudicate a claim even if a constitutional case or controversy is present. ${ }^{230}$ Justiciability considerations can play a role at the outset of the litigation, when the question is one of standing, or during the pendency of a lawsuit, when the claim of the representative plaintiff, although not that of the class, may become moot.

The Supreme Court set forth principles for class action standing in O'Shea $v$ Littleton, ${ }^{231}$ a suit for injunctive relief against municipal officials for alleged racial discrimination in the performance

Expenses in Shareholders' Derivative Suits, 4 Colum J L \& Soc Probs 50, 65 (1968). These statutes are inapplicable in federal question actions. See Fielding $v$ Allen, 181 F2d 163, 168 (2d Cir 1950).

228 FRCP 11.

220 US Const, Art III, § 2, cl 1.

2s0 See, for example, Singleton v Wulf, 428 US 106, 112-16 (1976) (justiciability rules embody additional, self-imposed restraints on the exercise of judicial power in addition to the constitutional minima). 2s1 414 US 488 (1974). 
of their official duties. The Court held that the complaint should have been dismissed for failure to establish a case or controversy under Article III because none of the named plaintiffs experienced any real or immediate threat of injury from the actions charged in the complaint. ${ }^{232}$ Thus, because "none of the named plaintiffs purporting to represent a class [had established] the requisite of a case or controversy with the defendants, none [could] seek relief on behalf of ... the class." ${ }^{233}$

The rule in O'Shea fails to take account of the realities of class action litigation. The complaint in that case had set forth numerous allegations of wrongdoing by the defendant municipal officials, allegations that were fully sufficient to establish injury in fact to some members of the class, even if not to the named plaintiffs. There was, further, obvious adversariness and concrete controversy between the class as represented by their attorneys (who evidently were in control of the litigation) and the defendants. Thus, all the requisites for Article III standing-injury in fact, adversariness, and concrete presentation of issues-were established in every functional sense.

The principal consequence of O'Shea is to deter civil rights and other litigation by making it more difficult for counsel to identify representative plaintiffs. If the goal of public policy is to reduce the level of such litigation, however (a matter on which we take no position), it would appear far better for the legal system to attack the problem directly-by, for example, altering substantive rules or enhancing burdens of proof-rather than by imposing an arbitrary filter that screens out litigation on the basis of whether plaintiffs' counsel has been able to persuade a suitable individual to file as class representative. The Court would have been better advised to allow the litigation to continue, on the theory that the named plaintiffs were mere figureheads in any event.

In contrast with its standing cases, the Supreme Court's approach to mootness in class actions has been quite sensible, although the Court has failed to carry the analysis to its appropriate conclusion. In Deposit Guaranty National Bank $v$ Roper, ${ }^{234}$ the district court denied class certification, required the named plaintiffs, over their objection, to accept defendant's tender of their individual damages, and then dismissed the complaint. The Supreme Court held that the named plaintiffs were entitled to appeal the

\footnotetext{
232 Id at $497-98$.

293 Id at 494 .

2s4 445 US 326 (1980).
} 
adverse certification ruling notwithstanding the apparent mootness of their individual claims, on the ground that the named plaintiffs had a continuing personal stake in class certification in order to "shift part of the costs of litigation to those who will share in its benefits if the class is certified and ultimately prevails." ${ }^{235}$ A companion case, United States Parole Commission v Geraghty, ${ }^{236}$ was a class action brought on behalf of potential federal parolees. The district court denied class certification and ruled for the defendant on the merits; the named plaintiff appealed the denial of class certification but was released from prison while the appeal was pending. The Supreme Court again held that the mootness of the individual claim did not vitiate the appeal because the named plaintiff retained a "personal stake" in obtaining class certification that survived the claim for relief on the merits. ${ }^{237}$

Geraghty and Roper carry mootness analysis beyond anything the Supreme Court has ever endorsed in traditional litigation settings. In both cases the named plaintiff's claim for relief on the merits had rather clearly been mooted out. Nor did these cases fit easily into the traditional mootness exception for cases "capable of repetition yet evading review." ${ }^{238}$ The Court in Geraghty was quite explicit that it was adjusting traditional mootness notions in order to accommodate "nontraditional forms of litigation, such as the class action." ${ }^{239}$ As Justice Powell observed in dissent, if the case were viewed in the light of standard mootness doctrine, it clearly "lack[ed] a plaintiff with the minimal personal stake that is a constitutional prerequisite to the jurisdiction of an Art. III court."240

In our view, the results in Geraghty and Roper are correct. A contrary rule would give class action defendants a tool to undermine the class action by buying off the named plaintiff, either by voluntary settlements or by giving the named plaintiff relief that the plaintiff cannot refuse. For example, in Geraghty, the federal government indicated that it was no longer willing to entertain the plaintiff as a guest in its correctional facilities, and in Roper the trial court crammed a settlement down the throats of unwilling class representatives. The opportunities for abuse in this situation

293 Id at 336.

2s6 445 US 388 (1980).

237 Id at 404 .

2s8 In earlier cases the Court had suggested that class action mootness could be analyzed under this traditional doctrine. See, for example, Sosna v Iowa, 419 US 393, 397-403 (1975).

230445 US at 402.

${ }^{210}$ Id at 424 (Powell dissenting). 
are patent. Second, these cases did not present a realistic threat to the policies underlying Article III: whether or not the named plaintiff's claim had become moot, there remained a concrete, live controversy in both cases with clearly framed issues for adjudication. The fact that the named plaintiffs may have lost a personal stake was hardly relevant as a realistic or functional matter given that these cases were controlled by plaintiffs' attorneys throughout. The departure of the named plaintiffs did not significantly change anything in the lawsuit. The decisions in Geraghty and Roper are consistent with the policies underlying both the class action rule and Article III, and take due account of the economic realities of class action litigation. ${ }^{241}$

Unfortunately, the Court in both cases found it necessary to force the result into traditional doctrinal categories by explaining that the named plaintiff maintained a personal stake in the litigation despite the mootness of the substantive claims. Here the Court indulged in analytically unsound fictions. Consider the argument in Roper that the named plaintiff had an interest in obtaining reimbursement for the costs of the litigation. The idea that the named plaintiffs, whose claims, inclusive of interest and court costs, amounted to $\$ 889.42$ and $\$ 423.54,{ }^{242}$ would willingly shoulder the costs of a class action with 90,000 claims $^{243}$ seems far-fetched. Although the plaintiffs asserted to the Court that they had a "continuing obligation" to pay the fees and expenses of the litigation, ${ }^{244}$ they did not say whether they intended to fulfill their obligation if the action were unsuccessful.

Even more absurd is the majority's assertion in Geraghty that the named plaintiff, a former federal prisoner, had a live personal stake in obtaining class certification. The Court pointed to no affidavit or other representation in the record as to why vindicating a purely procedural "right" might have been important to the named plaintiff when the plaintiff had nothing to gain from the litigation on the merits. The Court suggested obliquely that the named plaintiff might obtain "certain benefits" from the class nature of

242 See Richard K. Greenstein, Bridging the Mootness Gap in Federal Court Class Actions, 35 Stan L Rev 897, 925 (1983) ("In a class action suit, the function of the named plaintiff, with respect to the claims of the class, is to represent the interests of putative class members, not to supply the injury needed to satisfy the case-or-controversy requirement of article III. This latter function is served by the class allegations themselves.").

${ }^{242}$ Roper, 445 US at 329.

243 Id at 328.

${ }^{244}$ Id at $334 \mathrm{n} 6$. 
the action. ${ }^{245}$ Neither the court nor the sources it cited indicated what those benefits might be. ${ }^{246}$ Perhaps the Court was implying that the named plaintiff hoped to obtain payoffs from class counsel for agreeing to front the litigation, but this hardly seems a justification for recognizing Article III standing in obtaining class certification. Moreover, the Court did not point to the potential disadvantages to the named plaintiff of class status: the probability that the named plaintiff would have to submit to an inquisition into her adequacy and typicality as class representative, ${ }^{247}$ and, crediting for the moment the Court's fiction of client repayment, the liability for the costs of the litigation, including class notice, if the suit were not successful.

These fictions might have been necessary in order to hold a majority, ${ }^{248}$ but their implications are unfortunate. They suggest an unnecessarily restrictive view of justiciability in class action and derivative litigation. Given the unique nature of class and derivative litigation, it should not be necessary to demand a representative plaintiff who fulfills traditional Article III requirements for injury in fact and a stake in the outcome. Both standing and mootness analysis rather require that the policies underlying Article III be served. In our view these policies are quite adequately served so long as (1) there exist some individual class members who have a concrete stake in the outcome sufficient to satisfy traditional justiciability requirements, and (2) class or derivative counsel who effectively control the litigation have framed the issues so as to create the requisite degree of adversary testing and protection against collusive litigation.

It should not be necessary from the standpoint of justiciability, in other words, that there be any named plaintiff at all. Because the named plaintiff is a mere figurehead who adds little or nothing to the conduct of the litigation in the large-scale, smallclaim setting, a talismanic focus on the nature of the named plaintiff as the key to justiciability appears misguided. A "Jane Doe" or "Richard Roe" complaint, asserting rights on behalf of as-yet unidentified class members, should be fully sufficient to satisfy jus-

\footnotetext{
246 Geraghty, 445 US at 403.

246 See Jonathan M. Landers, Of Legalized Blackmail and Legalized Theft: Consumer Class Actions and the Substance-Procedure Dilemma, 47 S Cal L Rev 842, 894-95 (1974); William Simon, Class Actions-Useful Tool or Engine of Destruction, 55 FRD 375 (1972), cited in Geraghty, 445 US at $403 \mathrm{n} 9$.

${ }^{247}$ See notes $281-83$ and accompanying text.

${ }^{248}$ Geraghty was a 5-4 decision. Four of the five majority Justices are still on the Court; the fifth, Justice Brennan, resigned in July, 1990.
} 
ticiability concerns when (1) the well-pleaded allegations establish the existence of some putative class members who would have standing if they brought suit individually; and (2) the court is satisfied that class counsel will present the issues in an appropriately adversary fashion. ${ }^{249}$

\section{Adequacy}

We now address the question of the adequacy of the named plaintiff. Unlike typicality, which goes to the closeness of fit between the named plaintiff's claim and those of absent class members or corporate shareholders, the adequacy rule requires that the named plaintiff provide "adequate"-that is, reasonably skillful, sufficiently financed, and appropriately zealous-representation of absent class members or the corporation.

The adequacy requirement is grounded most immediately in the applicable federal rules, which require as a precondition to the maintenance of class or derivative litigation that the named plaintiff be an adequate representative of the class or corporation. ${ }^{250}$ Due process concerns, however, underlie the requirements; a plaintiff cannot be constitutionally bound by the res judicata effect of a decree when the interests of absent class members have not been adequately protected..$^{251}$

We argue that, at least as presently administered, the adequacy requirement is among the least sensible and most perverse of all the regulations governing entrepreneurial litigation. The absurdity of the adequacy requirement as presently administered is heightened when it is considered in conjunction with the typicality rules because there is considerable tension between these two sets of principles. Read for all they are worth, these two bodies of doctrine create something of a Catch-22: if a representative plaintiff is

${ }^{249}$ See, for example, Harry Kalven, Jr. and Maurice Rosenfield, The Contemporary Function of the Class Suit, $8 \mathrm{U}$ Chi L Rev 684, 718 n 98 (1941) ("the requirement of the initial client [seems] anachronistic; the class is the real client and the situation does not readily adjust to orthodox notions of the lawyer-client relationship"); Note, Class Standing and the Class Representative, 94 Harv L Rev 1637, 1638 (1981).

280 See FRCP 23(a)(4); 23.1.

${ }^{281}$ Hansberry $v$ Lee, 311 US 32, 42-46 (1940) (granting relief from judgment when representative plaintiffs had interests adverse to the interests of class members not before the court); Gonzales $v$ Cassidy, 474 F2d 67, 75 (5th $\mathrm{Cir}$ 1973) (granting relief from the judgment when representative plaintiff failed to appeal ruling granting relief to the representative plaintiff alone and denying relief to other class members). See Comment, The Importance of Being Adequate: Due Process Requirements in Class Actions Under Federal Rule 23, $123 \mathrm{U}$ Pa L Rev 1217, 1219 (1975). 
typical, she is, virtually for that reason alone, not adequate, and a plaintiff who satisfies the adequacy rules is generally not typical.

The adequacy requirement assumes importance with respect to two principal questions: (1) will the litigation be adequately supported financially; and (2) will the legal representation be reasonably competent.

1. Financial support of the litigation.

Defendants sometimes attempt to take the deposition of the representative plaintiff for the purpose of discovering whether the plaintiff will be able to support the litigation financially. ${ }^{262}$ Underlying this discovery is the theory that the representative plaintiff pays the costs of the litigation if the suit is unsuccessful. This allocation of responsibility between named plaintiff and attorney flows from the Model Code of Professional Responsibility, applicable in approximately half the states, which allows an attorney to advance the client the expenses of litigation "provided the client remains ultimately liable for such expenses."253 These expenses include "court costs, expenses of investigating, expenses of medical examination, and costs of obtaining and presenting evidence."254 Most importantly, in the class action context the representative plaintiff is liable for the costs of notice. ${ }^{280}$ Thus, in theory at least, the named plaintiff may ultimately be liable for notice costs running into the hundreds of thousands of dollars in the event that the litigation is unsuccessful.

To the extent it is actually enforced, the rule that the named plaintiff must have sufficient resources to support the litigation, including the costs of class notice, would appear to be utterly without merit, at least as applied to the large-scale, small-claim class action or derivative suit. A stringent financial adequacy requirement in this context would greatly reduce the number of cases that

${ }^{262}$ See generally Note, Discovery of Plaintiff' Financial Situation in Federal Class Actions: Heading 'em Off at the Passbook, 30 Hastings L J 449 (1978); Comment, Class Certification: Relevance of Plaintiff's Finances and Fee Arrangements With Counsel, $40 \mathrm{U}$ Pitt L Rev 70 (1978).

${ }^{25 s}$ Model Code DR 5-103(B). Under the more recently promulgated Model Rules, the plaintiff need not be ultimately liable for expenses. See Rule 1.8(e)(1).

258 Id.

2ss Eisen $v$ Carlisle \& Jacquelin, 417 US 156, 178-79 (1974) ("The usual rule is that a plaintiff must initially bear the cost of notice to the class. ... [T] [Te plaintiff must pay for the cost of notice as part of the ordinary burden of financing his own suit."). Eisen stands for the proposition that ordinarily the plaintiff, not the defendant, is liable for notice costs; it does not itself speak to the issue of whether the plaintiff's attorney can advance notice costs to the plaintiff with repayment contingent on success. The latter issue is governed by the applicable ethics rules. 
are brought. Few representative plaintiffs would be foolish enough to agree to bear the high expenses of class or derivative litigation in the event of nonsuccess when their expected recovery from the lawsuit is much lower than their expected costs. If financial adequacy were truly taken seriously, the large-scale, small-claim class action would wither on the vine.

The financial adequacy rule is based on a palpable fiction. Everyone understands that attorneys support the litigation, and that if the case is unsuccessful the attorney will not ask for reimbursement of costs from the representative plaintiff. ${ }^{258}$ The only difference, in this regard, between an ethical plaintiffs' attorney and an unethical one is that the ethical attorney might actually send the client a bill to provide a paper record of compliance with DR 5-105(B). Along with the bill might be a conspicuous wink or suggestion that the client file the bill in the waste basket. Attorney payment of costs in large-scale, small-claim class and derivative litigation is inevitable given the economic structure of class and derivative litigation. The inquiry into the adequacy of the representative plaintiff's finances is a preposterous charade.

Neither does the financial adequacy requirement protect absent class members or the corporation. The Model Code suggests that allowing the attorney to pay the costs will impair her professional judgment. ${ }^{267}$ The Model Code does not, however, spell out how the attorney's professional judgment might be impaired. Perhaps the reason is that the attorney might be more inclined to settle a case on relatively unfavorable terms to the client in order to assure the repayment of costs. This theory is not completely implausible because the inherent conflict of interest between attorney and client over the matter of settlement is conceptually more acute when costs, rather than fees, are at issue. Costs are typically deducted from the settlement fund first, with the remainder allocated between lawyer and client according to the applicable procedure for determining attorney fees. The attorney who has advanced costs subject to a risk of nonsuccess would much prefer to settle out at a low sum in order to assure that the costs will be

\footnotetext{
${ }^{268}$ See, for example, Janet E. Findlater, The Proposed Revision of DR 5-103(B): Champerty and Class Actions, 36 Bus Law 1667, 1670, 1672 n 27 (1981); Theresa A. Gabaldon, Free Riders and the Greedy Gadfly: Examining Aspects of Shareholder Litigation as an Exercise in Integrating Ethical Regulation and Laws of General Applicability, 73 Minn L Rev 425, 441 (1988) (contingent costs arrangements are "virtually an essential concomitant of section 16(b) enforcement"); Mark Lynch, Ethical Rules in Flux: Advancing Costs of Litigation, 7 Litigation 19, 20 (Winter 1981).

${ }^{25 z}$ See note 253 and accompanying text.
} 
repaid. In a broader context, however, the theory underlying the ban on attorney advances of litigation costs with repayment contingent on success appears questionable at best. The attorney operating on a contingent fee basis has a far greater conflict of interest with the client based simply on the fee allocation. If conflicts of this sort are to be permitted, it is difficult to see why the relatively minor conflict over contingent costs should be banned, especially when requiring the client to pay the costs is likely to prevent many suits from ever being brought.

Allowing the defendant to delve into the representative plaintiff's finances also represents an obvious intrusion on privacy. Courts have sometimes allowed a defendant to discover tax returns and other personal financial information that the plaintiff might prefer to keep private. ${ }^{288}$ The defendant might also ask the representative plaintiff whether she is obligated and intends to repay the attorney for costs in the event the litigation is unsuccessful. 259 The representative plaintiff may then have to perjure herself by stating that she does indeed intend to repay the attorney.

Finally, to the extent it is enforced vigorously, a financial adequacy rule will dramatically reduce the supply of attorneys able to conduct derivative litigation. The attorney must now identify a representative plaintiff who is not only a valid class representative or derivative shareholder, in the sense of having a suitable claim, but who in addition has considerable personal wealth, a relatively underdeveloped sense of personal privacy, the toughness of mind to withstand adversary grilling at a deposition, and, possibly, the willingness to perjure herself for the benefit of the other class members and the plaintiff's' attorney. Such individuals are surely uncommon. Any representative plaintiff who meets the conditions for financial adequacy is thereby rendered suspect as a typical

\footnotetext{
${ }^{288}$ See, for example, Rodriguez v Banco Central, 102 FRD 897, 902 (D Puerto Rico 1984); Gordon v Hunt, 98 FRD 573, 579 (S D NY 1983); Strong $v$ Arkansas Blue Cross and Blue Shield, Inc., 87 FRD 496, 510 (E D Ark 1980); Rode v Emery Air Freight Corp., 76 FRD 229, 233 (W D Pa 1977) (financial data is relevant to the adequacy of representation because of the danger that attorney may use the threat of fund revocation to "coerce the representative plaintiff into complying with his attorney's position"). But see Sanderson v Winner, 507 F2d 477, 478 (10th Cir 1974) (district court improperly allowed discovery of named plaintiff"s "[c]urrent financial statements, income tax returns for the years 1972 and 1973, and any other writings or documents reflecting plaintiffs' ability to finance the expenses that may be involved in this purported class action litigation").

${ }^{250}$ See Sanderson, 507 F2d at 478 (district court allowed discovery of "[a]ny agreements plaintiffs have made, collectively or individually, among themselves, with their attorneys of record herein and with any other persons, pertaining to (a) the financing of the costs of this litigation, and (b) the payment of attorneys' fees that might be incurred").
} 
class member because she is likely to have special financial interests in the litigation and a much higher level of financial sophistication than is typical of the plaintiff group generally.

Often the court will profess itself satisfied with the named plaintiff's representations as to assets and earning power, even though, as we have noted, there is reason to be highly suspicious of the named plaintiff's intent to repay class counsel in the event of nonsuccess. ${ }^{260}$ In a number of cases, however, courts have imposed perverse and unwarranted results on the plaintiff class on the ostensible ground that they needed to be protected against the attorney paying the litigation costs. For example, in In re Mid-Atlantic Toyota Antitrust Litigation, ${ }^{261}$ the defendant was allowed to inquire by way of interrogatories as to whether the representative plaintiffs were willing and able to finance the costs of the litigation as a class action. Apparently unwilling to perjure themselves, the plaintiffs stated that their law firms were advancing the costs of the litigation, and that they understood the law firms followed a policy of not seeking reimbursement from the class representatives in the event of nonsuccess. ${ }^{262}$ The court denied class certification on the ground that "[i]f the client is not financially responsible, the attorneys have free rein over the prosecution of the action."2183 Thus the court protected the absent class members by effectively denying them the opportunity of any recovery at all. ${ }^{264}$

\footnotetext{
${ }^{280}$ For cases where the court accepted the plaintiff's assertion that she would assume ultimate responsibility for legal costs despite lack of current resources, see County of Suffolk v Long Island Lighting. Company, 710 F Supp 1407, 1413 (E D NY 1989); Gordon v Hunt, 98 FRD 573, 579 (S D NY 1983).

281 93 FRD 485 (D Md 1982), aff'd as Commonwealth of Pennsylvania v Mid-Atlantic Toyota Distributors, Inc., 704 F2d 125 (4th Cir 1983).

${ }^{282} 93$ FRD at 489.

${ }^{28 s}$ Id at 490. See also Klusman v Bucks County Court of Common Pleas, 564 A2d 526, 532-33 ( $\mathrm{Pa}$ Commw 1989), aff'd per curiam, 574 A2d 604 ( $\mathrm{Pa} 1990$ ) (named plaintiffs were not adequate class representatives because fee arrangement excused them liability for costs if the suit were unsuccessful).

${ }^{204}$ See also Palmer v BRG of Georgia, Inc., 874 F2d 1417, 1420-21 (11th Cir 1989) (trial court did not abuse its discretion in refusing to certify class because named plaintiffs stated that they were only capable of assuming the cost of mailing notice to approximately 280 absent class members); Lim $v$ Citizens Savings and Loan Assn., 430 F Supp 802, 812-13 (N D Cal 1976) (decision to deny class certification supported in part by named plaintiff's refusal to indicate the nature of the fee arrangement); Held v Missouri Pacific R.R. Co., 64 FRD 346, 350 (S D Tex 1974); Ralston v Volkswagenwerk, A.G., 61 FRD 427, 433-34 (W D Mo 1973).

In at least one other case the court used the inadequacy of financing as a reason for drastically limiting the scope of the plaintiff class. See P.D.Q. Inc. of Miami v Nissan Motor Corp., 61 FRD 372 (S D Fla 1973), aff'd as In re Nissan Antitrust Litigation, 577 F2d 910 (5th Cir 1978) (based on named plaintiffs' depositions, court concluded that they could not pay more than a few thousand dollars to support the litigation, and accordingly rejected
} 
Fortunately, many trial courts have administered the adequacy rule in a more sensible fashion, even at the expense of conceptual tension between the stated rule and the rule administered by the courts. For example, in Sayre v Abraham Lincoln Federal Savings \& Loan Ass'n, defendants asked the named plaintiffs at depositions to disclose information on "the extent of their financial assets, their understanding of how the costs of prosecuting [the] suit [were] to be met, and their understanding of their arrangement with their counsel for meeting these costs." ${ }^{265}$ Observing that "to deny a class whenever plaintiffs' counsel advances significant funds to plaintiffs of little or modest means would be to defeat the very purposes which class actions were designed to achieve,"268 the court granted a protective order against the discovery. The decision in Sayre is not easily reconciled with the theory that the plaintiffs would be ultimately liable for costs or with the general rule of discovery that the defendant can obtain access to "any matter, not privileged, which is relevant to the subject matter involved in the pending action ...."267 It is, however, an eminently sensible result from the standpoint of the true economic realities involved in large-scale, small-claim class and derivative litigation. ${ }^{288}$

Other courts have crafted rules of substance, as opposed to discovery, that tend to mitigate the perverse results of a stringent financial adequacy requirement. In the Southern District of New York, for example, the primary arena for much class action securities litigation, the named plaintiff satisfies her burden on financial adequacy by testifying in deposition that counsel is advancing the costs, and that there are no factors present such as pending bankruptcy or financial distress that cast doubt on plaintiff's ability to reimburse her attorney. ${ }^{269}$ This approach finesses the requirement

nationwide class action certification, permitting only narrowly defined subclasses for which the court deemed the plaintiffs to have adequate financing).

${ }^{283} 65$ FRD 379, 380-81 (E D Pa 1974).

268 Id at 385.

267 FRCP 26(b)(1).

${ }^{268}$ For other cases denying discovery into the representative plaintiff's finances, see Sanderson v Winner, 507 F2d 477 (10th Cir 1974); In re Alcoholic Beverages Litigation, 95 FRD 321, 326 (E D NY 1982); In re McDonnell Douglas Corp. Securities Litigation, 92 FRD 761, 762 (E D Mo 1981); Klein v Checker Motors Corp., 87 FRD 5, 6 (N D Ill 1979).

${ }^{260}$ See Stern v Carter, 82 AD2d 321, 441 NYS2d 717, 730 (1981) ("unless a court directs otherwise, based on sufficient independent evidence raised by defendant as to a plaintiff's inability to finance a class action either personally or through other sources, a defendant in a pretrial deposition of plaintiff should be limited to general questions in that regard"). See also Genden v Merrill, Lynch, Pierce, Fenner \& Smith, Inc., 114 FRD 48, 53 (S D NY 1987); Greene v Emersons Ltd., 86 FRD 47, 63 (S D NY 1980); Kamens v Horizon Corp., 81 FRD 444, 446 (S D NY 1979). This rule does not always protect the named plain- 
of financial adequacy by establishing as a rule of law that the plaintiff satisfies the adequacy burden if she is not in financial distress when the attorney is advancing the costs. Again, the approach is heavily flavored by fiction because the plaintiff's financial position, distressed or flush, is essentially irrelevant to the adequacy of representation in large-scale, small-claim class and derivative litigation. However, the dubiety of the fiction may be justified by the soundness of the result.

Although these partial responses, which today represent the clear majority opinion among the federal and state courts, ${ }^{270}$ mitigate the worst aspects of the financial adequacy rule, it would be far better, in our view, for the regulatory system to abandon the whole skein of fictions and adopt a sensible and pragmatic approach to the problem of financial adequacy in the case of largescale, small-claim class actions. The courts should forthrightly acknowledge that the financial resources of the named plaintiff in such cases are irrelevant. ${ }^{271}$ The attorney pays the litigation expenses and does not seek reimbursement if the suit is unsuccessful. ${ }^{272}$ What matters, therefore, is not the financial resources of the named plaintiff, but the financial resources of the attorney.

Thus, if the named plaintiff states under oath that counsel is advancing the costs of the litigation, the trial court should prohibit any further inquiry into the financial adequacy of the named plaintiff. Rather, the trial court should investigate the financial resources of the plaintiffs' attorney. Such an inquiry should be conducted by the trial court, and not by defense counsel, both because the defendant has no legitimate interest in ensuring that the plaintiffs' attorneys' resources are adequate, and because of the serious dangers of abuse that would arise if opposing counsel could depose

tiff against deposition into her financial status, however. See, for example, Moll v U.S. Life Title Insurance Co. of New York, 113 FRD 625, 632 (S D NY 1987) (allowing discovery into named plaintiff's financial status because defendant had raised questions regarding her ability to pay for the litigation).

${ }^{270}$ See Getzendanner, 15 Litigation at 28 (cited in note 191) ("there may be some vitality left to financial inquisitions, but not much").

${ }^{271}$ For a case that comes close to doing so, see Harris $v$ General Development Corp., 127 FRD 655, 662 (N D Ill 1989) (refusing to deny class certification even though plaintiffs would not be liable for expenses in the event of nonsuccess because "a contrary ruling under these circumstances would prevent plaintiffs of modest means from pursuing a class action").

${ }^{272}$ See County of Suffolk v Long Island Lighting Co., 710 F Supp 1407, 1413 (E D NY 1989) ("We recognize that, were the suit unsuccessful and no fund recovered, it would be most unusual for the attorney for a class to seek to recover legal fees and expenses from a few, relatively poor, named class representatives. This is the reality of class litigation. It should not be ignored by the courts."). 
plaintiffs' attorneys as to their resources. It would be appropriate for such an inquiry to be conducted ex parte, on plaintiffs' counsel's motion, if the trial court determines that disclosure to the defendant of the plaintiffs' attorneys' financial resources could be prejudicial to the class's or corporation's chances in the litigation. Alternatively, the trial court should be prepared to accept a bond posted by plaintiffs' counsel to provide assurance of financial adequacy. ${ }^{273}$

\section{Competence of representation.}

A second area of obvious importance to the adequacy analysis is that the legal representation of the class or corporation must be "adequate." Even if the lawsuit is generously financed, the absent class members would hardly receive due process if they were bound by a decree obtained against them as a result of egregiously incompetent legal representation. ${ }^{274}$ In class and derivative settings the challenge to the competence of representation is most often made by the defendant in opposition to plaintiff's motion for class certification. The theory typically is that the representative plaintiff is not sufficiently sophisticated in legal matters to monitor the plaintiffs' attorney and ensure that the class or corporation receives adequate legal representation.

From the defendant's point of view, the utility of this strategy has long been limited by the Supreme Court's leading precedent in the area, Surowitz $v$ Hilton Hotels Corp. ${ }^{275}$ The defendants established on deposition that the derivative plaintiff, a "Polish immigrant with a very limited English vocabulary and practically no formal education," could not explain the statements made in the complaint, [] had a very small degree of knowledge as to what the lawsuit was about, [] did not know any of the defendants by name, [] did not know the nature of their alleged misconduct, and in fact . . . had merely relied on what her son-in-law had explained to her about the facts in the case."277 The trial court dismissed the complaint on the ground that it had been falsely verified, ${ }^{278}$ but the Supreme Court held

\footnotetext{
${ }^{273}$ See, for example, Stern v Carter, 82 AD2d 321, 441 NYS2d 717, 731 (1981).

274 There are obvious analogies in the Sixth Amendment right to the effective assistance of counsel. See, for example, United States $v$ Cronic, 466 US 648, 653 (1984).

${ }^{278} 383$ US 363 (1966).

278 Id at 368 .

273 Id at 366 .

${ }^{278}$ The federal rule then applicable to derivative litigation, Rule 23(b), required that the complaint be "verified by oath" and contain specified averments. See 383 US at 365 n 4 . Current Rule 23.1 continues to require a verified complaint.
} 
that the named plaintiff's ignorance should not have barred the litigation, since it was evidently not a strike suit and the named plaintiff was exactly the type of small investor most in need of protection.

Despite its apparently strong facts, Surowitz has not foreclosed inquiry into the plaintiff's sophistication. First, the plaintiff in Surowitz had relied on the financial advice of her son-in-law, a Mr. Brilliant, who had graduated from Harvard Law School, possessed a master's degree from Columbia University, and "wore a Phi Beta Kappa key."278 Whatever intellectual or educational deficiencies might have characterized the named plaintiff were apparently more than offset by her wise decision to follow the instructions of her outstanding son-in-law. Second, the applicable federal rule at the time of the Surowitz decision did not contain an adequacy requirement; the case was decided on the ground of verification. Technically Surowitz has no bearing on the current adequacy requirement of Rule 23.1, which became effective after that decision. ${ }^{280}$

Defendants continue to depose the representative plaintiff for the ostensible purpose of determining whether that individual has sufficient intellectual capacity and legal acumen to supervise class or derivative counsel. ${ }^{281}$ The Supreme Court added a certain credibility to this line of inquiry in East Texas Motor Freight System, Inc. $v$ Rodriguez, ${ }^{282}$ where the Court held that a class action should not have been certified because (among other things) the named plaintiffs had failed to protect the absent class members by moving for class certification prior to trial. This error, in the Court's view, "surely bears strongly on the adequacy of the representation that those class members might expect to receive." ${ }^{283}$ The implication

278383 US at 368.

${ }^{280}$ It is perhaps noteworthy, however, that the Supreme Court approved proposed Rule 23.1 on February 28, 1966 (effective July 1, 1966), a mere week before the Surowitz case was handed down on March 7, 1966.

${ }^{281}$ See, for example, Rothenberg $v$ Security Management Co., Inc., 667 F2d 958, 962 (11th Cir 1982) (defendant took a "series of exhaustive depositions" of representative plaintiff and inquired repeatedly into her knowledge of the factual basis and legal issues in the complaint); Gordon v Hunt, 98 FRD 573, 579 (S D NY 1983); Greenspan v Brassler, 78 FRD 130, 133-34 (S D NY 1978); Kaufmann v Credithrift Financial, Inc., 465 NE2d 207, 209, 210-11 (Ind App 1984).

${ }^{282} 431$ US 395 (1977).

${ }^{283}$ Id at 405. But see Robert Alan Insurance Agency $v$ Girard Bank, 107 FRD 271, 27374 (E D Pa 1985) (holding named plaintiff to be an adequate class representative despite failure to file motion for class certification within time deadlines set by local rule on the ground that the error was due to counsel's negligence). 
appears to be that a named plaintiff, to be "adequate," must be . competent to make informed decisions such as whether or not to seek class certification prior to trial; and the plaintiff's qualifications in this regard would appear, at least as a matter of logic, to be appropriate subjects for inquiry through deposition or other discovery technique. While courts generally refuse to deny class certification on the ground that the named plaintiff lacks the ability to monitor the attorney, ${ }^{284}$ there remains a significant thread of doctrine, with some Supreme Court support, indicating that at least some minimal monitoring skills on the part of the named plaintiff may be required in order to establish the individual's adequacy as class or derivative representative. ${ }^{285}$

This thread of doctrine is bizarre, at least as applied to the large-scale, small-claim class or derivative suit. As we have noted repeatedly, the named plaintiff simply is not equipped to monitor the activities of the plaintiffs' counsel; any claim that named plaintiffs do monitor counsel in such cases is purest confabulation. This is true whether the named plaintiff is one of low educational level and legal sophistication, like Mrs. Surowitz, or the holder of advanced degrees and a Phi Beta Kappa key, like Mr. Brilliant.

In large-scale, small-claim litigation, the courts should forthrightly acknowledge that the named plaintiff is a figurehead and should accordingly prohibit any inquiry by the defendant into the

${ }^{284}$ See, for example, Kirkpatrick v J.C. Bradford \& Co., 827 F2d 718, 727 (11th Cir 1987) ("adequate class representation generally does not require that the named plaintiffs demonstrate to any particular degree that individually they will pursue with vigor the legal claims of the class"); Klein v A.G. Becker Paribas, Inc., 109 FRD 646, 651 (S D NY 1986) ("recent trend in this district is to assess the adequacy of the representative's attorney rather than the personal qualification of the named plaintiff"); Wolfson $v$ Riley, 94 FRD 243,245 (N D Ohio 1981) (class representative need not be "knowledgeable, intelligent, or possess[] a firm understanding of the legal or factual basis on which a class action can be maintained"); Simon v Westinghouse Electric Corp., 73 FRD 480, 485-86 (E D Pa 1977) ("Although the plaintiffs have demonstrated in deposition that they do not possess a thorough knowledge of all aspects of their claims, a detailed knowledge on the part of nonlawyers of what acts might create liability under section $10 \mathrm{~b}-5$ cannot be expected and is not required of a class representative.").

${ }^{285}$ See, for example, Rothenberg $v$ Security Management Co., Inc., 667 F2d 958, 962 (11th Cir 1982) (derivative plaintiff who "lacked any understanding of the nature of the derivative suit and displayed an unwillingness to learn" was not an adequate representative); Wright v Stone Container Corp., 524 F2d 1058 (8th Cir 1975) (certification denied in part on the ground that representative plaintiff had failed to join union as a defendant when under the facts and prevailing law union potentially bore some responsibility for the alleged unlawful employment practices); Weinstein v American Biomaterials Corp., 123 FRD 442, 466 (S D NY 1988); Efros v Nationwide Corp., 98 FRD 703, 708 (S D Ohio 1983); Massengill $v$ Board of Education, 88 FRD 181, 186 (N D Ill 1980); Helfand $v$ Cenco, Inc., 80 FRD 1, 7 (N D Ill 1977). 
named plaintiff's intellect, educational achievements, or understanding of the case. Allowing such inquiry merely serves to harass and invade the named plaintiff's privacy and to reduce artificially the supply of representative plaintiffs, further concentrating and limiting the availability of legal services by plaintiff's attorneys. Indeed, because the named plaintiff is a figurehead, the adequacy of representation would not be harmed if plaintiffs' attorneys could file "Jane Doe" or "Richard Roe" complaints on behalf of a fictitious absent class member without supplying an actual carcass for grilling over the hot coals of a deposition.

The relevant inquiry should not be the intellectual ability and legal acumen of the named plaintiff, but rather the vigor, skill, and experience of the plaintiff's' attorney. ${ }^{286} \mathrm{~A}$ number of courts have recognized this fact and have acknowledged their responsibility to police the competence of plaintiffs' counsel. ${ }^{287}$ Courts also occasionally police attorney competence with the threat of judicial sanctions. ${ }^{288}$ For the most part, however, the courts have not been willing to undertake any real scrutiny into the plaintiffs' attorney's

${ }^{286}$ See William E. Haudek, The Settlement and Dismissal of Stockholders' Actions-Part II: The Settlement, 23 Sw L J 765, 767-68 (1969). A case like East Texas Motor Freight, 457 US at 147 (see text at notes 218-19) should probably be understood as a disguised comment on the plaintiffs' attorney's competence given the obvious fiction involved in assuming that the named plaintiffs could be expected to understand the need to seek class certification.

${ }^{287}$ See, for example, Fendler $v$ Westgate-California Corp., 527 F2d 1168, 1170 (9th Cir 1975); In re Joint Eastern and Southern Districts Asbestos Litigation, 132 FRD 332 (E D NY and S D NY 1990); County of Suffolk $v$ Long Island Lighting Co., 710 F Supp 1407, 1419 (E D NY 1989), aff'd, 907 F2d 1295 (2d Cir 1990); Harman v Lyphomed, Inc., 122 FRD 522, 528 (N D Ill 1988); Mechigian v Art Capital Corp., 612 F Supp 1421, 1433 (S D NY 1985); Weinberg v Lear Fan Corp., 102 FRD 269, 272 (S D NY 1984).

For obvious reasons, courts scrutinize the competence of representation when the class representative is proceeding pro se. See, for example, Johnpoll $v$ Thornburgh, 898 F2d 849 (2d Cir 1990), cert den 111 S Ct 63 (1990) (upholding trial court's refusal to certify a class based in part on pro se litigant's inability to represent adequately the absent class members).

${ }^{288}$ See, for example, Hatch v Reliance Insurance Co., 758 F2d 409, 416 (9th Cir 1985) (court sua sponte imposed sanction against plaintiffs' attorney, observing that “[c]ounsel's performance in these proceedings demonstrates an inability to adequately and competently represent a single plaintiff, much less a class of plaintiffs"); Elster $v$ Alexander, 122 FRD 593, 604 (N D Ga 1988); Danik, Inc. $v$ Hartmarx Corp., 120 FRD 439 (D DC 1988), aff'd in relevant part, 875 F2d 890 (DC Cir 1989), rev'd on other grounds and remanded as Cooter \& Gell v Hartmarx Corp., 110 S Ct 2447 (1990). Although sanctions are occasionally directed at the client as well as the attorney, see Danik, 120 FRD at 445 (sanction divided between attorney and named class representative), in the large-scale, small-claim context it would make no sense to impose sanctions on the named plaintiff. Indeed, the threat of sanctions against named plaintiffs in this context would potentially further reduce the supply of available plaintiffs, although to date Rule 11 does not appear to have been frequently applied against named plaintiffs in such cases. 
qualifications. They typically engage in only the most perfunctory oversight, ${ }^{289}$ sometimes using their putative obligation to police the plaintiffs' attorney's adequacy as an excuse for administering fulsome compliments. ${ }^{290}$ Often defense counsel, either as a matter of strategy $^{291}$ or professional courtesy, will not contest the competence of the plaintiffs' attorney. In such cases the courts usually decline to make any kind of inquiry despite the obvious unreliability of defendant's representations regarding the plaintiffs' attorney's skills. ${ }^{292}$

The courts' diffidence in evaluating the competence of plaintiffs' counsel is not difficult to understand. A court, after all, is supposed to be a neutral umpire between plaintiff and defendant. It stretches this idea to require the court to act as de facto manager for one of the teams. Further, evaluating lawyer competence is exceedingly difficult when the matters involved are ones of judgment rather than simple adherence to rules. There may be few criteria, other than the court's subjective reactions, on which to base an assessment of the plaintiffs' attorney's competence when it comes to the most fundamental litigation decisions. While the court may appropriately use experience in similar litigation as a proxy for competence, the measure is quite inexact, for experienced lawyers may in fact be less capable than aggressive new entrants into the field. Accordingly, despite the theoretical value of a judicial inquiry into attorney competence, there are a variety of practical impediments to actually carrying out such a regulatory program.

As a practical matter, however, the policing of the plaintiffs' attorney's competence must be left to the discretion of the trial court. If the trial court determines at any point in the litigation that the class or corporation is receiving representation of exceptionally low quality, it would be appropriate for the court to insist

\footnotetext{
289 See, for example, Grace v Perception Technology Corp., 128 FRD 165, 170 (D Mass 1989) (court rejected defendant's attack on plaintiff's attorneys' ability with the comment "[t]he court is convinced that plaintiff's counsel will vigorously prosecute this action and are qualified to do so"); Getzendanner, 15 Litigation at 30 (cited in note 191); Note, 89 Harv L Rev at $1471 \mathrm{n} 93$ (cited in note 85).

${ }^{200}$ See, for example, Mashburn v National Healthcare, Inc., 684 F Supp 660, 672 (M D Ala 1988) (in upholding settlement, court praised plaintiff's counsel as "one of the most able and experienced trial lawyers in the State of Alabama").

${ }^{201}$ See Charles Donelan, Prerequisites to a Class Action Under New Rule 23, $10 \mathrm{BC}$ Indust \& Comm L Rev 527, 536 (1969) (attacking competence of plaintiffs' attorney can be "strategically disastrous" unless charge is specific and supported by solid evidence).

${ }^{202}$ See, for example, Kirby v Cullinet Software, Inc., 116 FRD 303, 311 (D Mass 1987) (noting that defendant did not contest attorney's adequacy).
} 
that co-counsel be appointed to take substantive control of the litigation. Relevant to a court's deliberations on this question would be an inquiry into whether the existing plaintiffs' counsel had engaged in any acts or omissions that would be inconsistent with the behavior of any reasonably competent attorney engaged in class or derivative litigation; missing filing deadlines or procedural defaults would be prime examples. The court's overall experience with counsel might also lead it to conclude that the lawyer is incapable of rendering even minimally competent legal representation. It might be useful to require the trial court to make explicit findings as to the plaintiffs' attorney's competence at the time of class certification and again when approving settlement in order to ensure that this issue is not entirely overlooked.

We doubt that this proposed judicial oversight of the competence of plaintiffs' counsel would affect results in many cases. For the most part courts would be expected to approve the attorneys without any difficulty. Our proposed approach offers two benefits over the existing regulatory system in this area, however. First, it directs attention away from the the misplaced focus on the representative plaintiff and to the plaintiffs' attorney. Second, our proposed approach would be likely, at some margin, to deter exceptionally poor legal representation, and in this respect it would serve the interests of absent class members or corporations as well as the legal system as a whole.

\section{Plaintiffs' Attorney's Ethics}

In addition to challenging the typicality or adequacy of the named plaintiff, defense counsel in large-scale, small-claim action class and derivative litigation may launch a direct attack on the plaintiffs' attorney by claiming some form of ethical default. Courts often permit the defendant to inquire into the ethics of the plaintiffs' attorney. The court may be asked to disqualify the plaintiffs' attorney if defense counsel can document conduct that violates or arguably violates applicable ethics rules.

This body of regulation is potentially the most quixotic of all the rules governing the conduct of class and derivative attorneys. If the rules were to be applied strictly, the result would be to exclude attorneys on ethics grounds who will be competent and zealous advocates of the plaintiff class, harming the very "clients" whom the ethics rules are ostensibly designed to protect.

Moreover, the policies underlying the ethics rules often suggest that the plaintiffs' attorney's conduct ought not to be considered a breach of professional ethics. In general, the ethics rules 
were devised to address problems that arise in a traditional litigation setting; they often have no relevance in the context of largescale, small-claim litigation, despite the fact that such litigations fall within the rules' literal language. Further, even if the conduct in question does violate the applicable ethics rules, this fact is not itself a sufficient justification for excluding the attorney on adequacy grounds from representing the class or the corporation. The assumption that an attorney who behaves unethically cannot be an adequate advocate for the class or corporation is simply wrong as a matter of theory. Codes of legal ethics are bodies of rules designed to regulate attorney behavior in order to protect clients, serve the well-being of society, and advance the interests of the legal profession. They have different purposes and arise from a different source than the adequacy requirement, which is designed to protect members of the absent plaintiff class. While behavior by an attorney that may be unethical under a state's ethics rules may (or may not) be relevant to the inquiry into the attorney's qualification to conduct the litigation, it is not-or not necessarily-dispositive. ${ }^{293}$

Attorneys whose ethics are challenged under the adequacy rule may be accised of a panoply of disciplinary violations. However, for purposes of exposition it is useful to separate out the key problem areas and to analyze them separately. The most important ethical violations typically alleged against class and derivative attorneys are (1) maintenance, (2) solicitation, (3) conflict of interest, and (4) creating the "appearance of impropriety."

\section{A. Maintenance}

A maintenance charge alleges that a third party interfered with or attempted to influence ongoing litigation by assisting or "maintaining" one of the litigants. ${ }^{294}$ As noted above, approxi-

\footnotetext{
${ }^{203}$ Judge Jack Weinstein, one of the most thoughtful commentators on the special problems of class and derivative litigation, may have been the first to make this observation. See County of Suffolk v Long Island Lighting Co., 710 F Supp 1407, 1413 (E D NY 1989) ("[a] federal court is not bound to enforce New York's view of what constitutes ethical professional conduct" when ruling on class certification). See also Harris v General Development Corp., 127 FRD 655, 662 (N D Ill 1989) ("[a]lthough the fee arrangement may give rise to a technical deviation from ethical standards, denial of class certification is unwarranted"); Gabaldon, 73 Minn L Rev at 429 (cited in note 256) (in litigation under $\$ 16(\mathrm{~b})$ of the Securities Exchange Act of 1934, behavior of attorney that technically violates ethical requirements can "actually further the goals of generally applicable law").

${ }^{294}$ See Black's Law Dictionary 860 (West, 5th ed 1979) (maintenance is "[a]n officious intermeddling in a suit which in no way belongs to one, by maintaining or assisting either party, with money or otherwise, to prosecute or defend it").
} 
mately half the states adhere to the Model Code of Professional Responsibility, which provides that while an attorney may advance the costs of litigation, the client must remain uitimately liable for such costs. ${ }^{295}$ Such jurisdictions would appear to prohibit agreements between plaintiffs' attorneys and named plaintiffs under which the attorney promises not to seek reimbursement for costs in the event the litigation is not successful. ${ }^{296}$

The problem of maintenance is closely intertwined with the issue of the representative plaintiff's financial adequacy. ${ }^{207}$ If the named plaintiff states at deposition that she is ultimately liable for costs, the defendant may argue that she lacks sufficient financial resources to support the litigation adequately and should therefore be disqualified as class or corporate representative. If, on the other hand, the named plaintiff states that her attorney will be ultimately liable for the costs, the defendant can then argue that the attorney should be disqualified for unethically maintaining the litigation. ${ }^{208}$

Although courts have sometimes concluded that the plaintiffs' attorney's maintenance of the litigation, alone or in combination with other factors, is a sufficient reason for excluding the attorney as an unreliable advocate for the interests of the class or corporation, ${ }^{299}$ we believe these cases are questionable at best because the costs of applying the disciplinary rule to large-scale, small-claim litigation far exceed the benefits of such a course.

Everyone knows that plaintiffs' attorneys routinely maintain litigation in apparent violation of DR 5-105(B), but there appear to be virtually no sanctions outside the limited context of disqualification determinations. If the rule were perfectly enforced, it would paralyze class and derivative litigation because no one would be willing to assume ultimate liability for costs. Analysis of social policy suggests, therefore, that DR 5-105(B) should not be a basis for excluding plaintiffs' attorneys in large-scale, small-scale class and derivative litigation.

${ }^{295}$ Model Code DR 5-105(B). The Model Rules drop the requirement that the client remain ultimately liable for expenses. See Model Rule 1.8(e)(1).

${ }^{296}$ But see notes 252-59 and accompanying text.

297 See notes $252-73$ and accompanying text.

${ }^{298}$ Trial courts, of course, do not enforce the ethics rules directly, but they have the authority to disqualify attorneys who appear before them on the ground that the representation is unethical.

${ }^{209}$ See, for example, Klusman $v$ Bucks County Court of Common Pleas, 564 A2d 526, 531-32 ( $\mathrm{Pa}$ Commw 1989), aff'd, 574 A2d 604 ( $\mathrm{Pa} \mathrm{1990)} \mathrm{(attorney} \mathrm{inadequate} \mathrm{in} \mathrm{part} \mathrm{because}$ agreement under which client would not be liable for costs in the event of nonsuccess was contrary to EC 5-8). 
There are two doctrinal bases on which a court may refuse to exclude the plaintiffs' attorney in a Model Code jurisdiction even if it it is established that the attorney will not seek reimbursement for costs from the client in the event of nonsuccess. First, it is by no means clear that DR 5-105(B) should apply to the case of largescale, small-claim class actions at all. If the purposes of a rule are not served by the application of the rule to a particular set of circumstances, it may be appropriate to create an implied exception even if none appears in the literal language. ${ }^{300}$ Because DR 5105(B)'s benefits are far outweighed by its costs, there is good reason to believe that the rule would not be applied literally in the large-scale, small-claim litigation context. In addition, any bar committee or court considering a proceeding against a plaintiffs' attorney under DR 5-105(B) might find it persuasive that the ABA and a large number of states have repudiated the rule that the plaintiff must remain ultimately liable for costs. ${ }^{301}$

Second, a determination that DR 5-105(B) applies and that the attorney violated the rule does not mean that the attorney should be disqualified in litigation. The attorney's qualification should be evaluated in terms of the actual risks to the client. The fact that the attorney is advancing the costs of the litigation and will remain ultimately liable for those costs if the suit fails is hardly a sufficient reason to remove her from the case. A court should deny the motion to disqualify the attorney, leaving for separate bar disciplinary proceedings the question of whether the plaintiffs' attorney should receive sanction for maintaining the litigation.

\section{B. Solicitation}

Another potential defense challenge to the plaintiffs' attorney's ethics is to assert that the attorney has solicited the named plaintiffs and thereby violated the relevant ethics rules. That such solicitation occurs on a regular basis is patently obvious. Indeed, in the context of large-scale, small-claim actions, it could not be otherwise. If attorneys were not able to contact potential clients to

\footnotetext{
${ }^{300}$ See note 88 and accompanying text.

sor Also, if the rule were applied literally to class and derivative plaintiffs for actions undertaken in federal court litigation, there is some possbility that the rule would be deemed preempted by the Federal Rules of Civil Procedure. Judge Weinstein suggests this in County of Suffolk v Long Island Lighiing Co., 710 F Supp 1407, 1414-15 (E D NY 1989) (dicta). We doubt that the preemption argument would find acceptance in many courts, however, because the conflict between the Federal Rules of Civil Procedure and the state's ethics regulations is only indirect.
} 
solicit their participation in the litigation as named plaintiffs, much litigation would not occur at all because clients with small claims would be very unlikely to seek out attorneys on their own.

'In-person solicitation of named plaintiffs by plaintiffs' attorneys would appear to violate the clear commands of the relevant ethics codes. Under the Model Code, a lawyer generally may not recommend herself as a private practitioner to any lay person who has not sought her advice, ${ }^{302}$ may not pay any kind of finder's fee, ${ }^{303}$ and may not use runners or touters to recommend the attorney's services. ${ }^{304}$ Under the Model Rules, an attorney may not solicit employment from a prospective client with whom the lawyer has no family or prior professional relationship "when a significant motive for the lawyer's doing so is the lawyer's pecuniary gain." ${ }^{305}$

These provisions of the Model Code and the Model Rules suggest the possibility of frequent defense motions to disqualify plaintiffs' attorneys on solicitation grounds. Fortunately, however, claims of unethical solicitation are fairly uncommon in class and derivative litigation. ${ }^{306}$ The relative infrequency of such claims is probably due to several factors. Any attempt by the defendant to probe into the named plaintiffs' relationship with the plaintiffs' attorney-other than an inquiry into their financial arrangements-would almost certainly be met with vigorous objections on grounds of privilege. ${ }^{307}$ The defendant may find it difficult to obtain concrete evidence that solicitation has indeed occurred. In the absence of established facts, courts are likely summarily to reject suggestions of solicitation based on circumstantial evidence or inference. ${ }^{308}$

${ }^{302}$ Model Code DR 2-103(A). See also Model Code EC 2-3.

${ }^{303}$ Model Code DR 2-103(B).

304 Model Code DR 2-103(C).

sos Model Rule 7.3.

${ }^{306}$ But see, for example, Halverson $v$ Convenient Food Mart, Inc., 458 F2d 927 (7th Cir 1972); Harris v General Development Corp., 127 FRD 655, 662 (N D III 1989); duPont Glore Forgan Inc. $v$ American Telephone and Telegraph Co., 69 FRD 481, 484 (S D NY 1975); Staurides v Mellon National Bank \& Trust Co., 60 FRD 634, 637 (W D Pa 1973) (inference of solicitation). See also Getzendanner, 15 Litigation at 30 (cited in note 191) ("[C]ourts [] disfavor lawyers who blatantly solicit-in fact create-a class action. . . . [Therefore,] defense counsel should consider questioning the named plaintiffs on how the case arose and how they chose their lawyers.").

${ }^{307}$ See Getzendanner, 15 Litigation at 30 (cited in note 191). Yet the attorney's behavior toward the client in soliciting participation as named plaintiff would not seem to fall within the normal scope of the attorney-client privilege, at least so long as the questions are carefully limited to the genesis of the litigation rather than touching on advice the attorney may have given the client or information the client may have provided to the attorney.

${ }^{308}$ See Harris v General Development Corp., 127 FRD 655, 662 (N D Ill 1989). 
In addition, there would today be serious constitutional difficulties with a rule that prohibited plaintiffs' attorneys from soliciting named plaintiffs in large-scale, small-claim class and derivative actions. Although such solicitation is no doubt made for pecuniary purposes, and therefore is not within the exception for "public interest" solicitation, ${ }^{308}$ the class action and derivative devices do have public interest components; they permit "private attorneys general" to enforce laws that would not otherwise be effectively administered. ${ }^{310}$ The dangers of undue influence and overreaching that take the regulation of classic ambulance chasing outside the protections of the First Amendment ${ }^{311}$ are not strongly present in the case of class and derivative suits; the named plaintiff's personal stake in such suits is usually low and the matters in issue are not central to the named plaintiff's well-being. There is good reason to suppose that the First Amendment protects solicitation of named plaintiffs in large-scale, small-claim class and derivative suits even though the attorney's motives in conducting the litigation may be pecuniary in nature. ${ }^{312}$

The relative infrequency of solicitation claims is reassuring, for it would be extremely inappropriate to exclude attorneys from class and derivative litigation on the ground that they solicited their clients. If a solicitation rule were enforced vigorously, the effect would be to reduce the efficacy of class and derivative suits and to further reduce the supply of potential named plaintiffs (thereby reducing the number of attorneys able to conduct the representation). To clear up any confusion, however, the courts should establish clearly and unequivocally that it is no objection to the adequacy of representation in large-scale, small-claim class and de-

\footnotetext{
${ }^{300}$ See In Re Primus, 436 US 412 (1978) (solicitation by nonprofit organization of prospective litigants to engage in public interest litigation protected by the First Amendment).

310 This point was repeatedly made by Professor Hornstein in a series of influential early articles. See, for example, Hornstein, 69 Harv L Rev at 662 (cited in note 66); George D. Hornstein, The Counsel Fee in Stockholder's Derivative Suits, 39 Colum L Rev 784, 787 (1939).

s11 See Ohralik v Ohio State Bar Assn., 436 US 447 (1978) (First Amendment did not protect in-person solicitation of injured accident victim where attorney's motive was pecuniary gain).

${ }^{312}$ See Vance G. Camisa, The Constitutional Right to Solicit Potential Class Members in a Class Action, 25 Gonzaga L Rev 95 (1989/90) (advocating broad rights of communication with absent class members); Gabaldon, 73 Minn L Rev at 449-64 (cited in note 256) (suggesting constitutional protections for solicition in derivative litigation context); Charles D. Schoor, Class Actions: The Right to Solicit, 16 Santa Clara L Rev 215 (1976) (same). See also Gulf Oil Co. $v$ Bernard, 452 US 89, 102-04 (1981) (trial court abused its discretion by barring communications between class counsel and absent class members because of the mere possibility of abuse by class lawyer).
} 
rivative suits that the attorney may have personally solicited the named plaintiff. ${ }^{313}$ (No concerns about solicitation would arise at all, of course, if plaintiffs' attorneys were allowed to bring "Richard Roe" or "Jane Doe" complaints on behalf of unidentified, absent class members.)

\section{Fee-splitting}

Defendants might also attempt to challenge the ethics of plaintiffs' attorneys on the ground that the attorneys have engaged in fee-splitting in violation of the applicable provisions of the Model Code, which prohibit lawyers from dividing fees with another lawyer who is not a partner in or associate of her law firm unless the arrangement is fully disclosed to the client and the client consents. ${ }^{314}$ The division of the fees must be "made in proportion to the services performed and responsibility assumed by each," and the total fee for all lawyers must be reasonable. ${ }^{316}$

Read literally, this provision would appear to be routinely violated in large-scale, small-claim cases. Such cases are ordinarily prosecuted by a consortium of firms on the plaintiff's side, which necessarily split fees upon conclusion of the case. The client cannot possibly consent to the fee-splitting for reasons already discussed: the costs of disclosure of the fee arrangement would be enormous in the class action context, and any "consent" obtained would be suspect because of the small interest of each individual class member. In the derivative litigation context, the "client"- the corporation-is under the control of hostile management, and accordingly cannot be expected to consent to anything requested by plaintiffs' counsel to aid them in the conduct of the litigation. Large-scale, small-claim litigation necessarily requires fee arrangements that are not based on the time spent on the case. For example, in some cases where clients are hard to come by, an attorney's principal contribution to a case may be to provide the representative plain-

313 See Newberg, 1 Class Actions $\$ 11200$ at 220 n 306 (cited in note 60) ("once courts candidly recognize the important role of lawyer-motivated class action litigation, enforcement of ethical prohibitions against solicitation of clients becomes questionable"). See also Halverson $v$ Convenient FoodMart Inc., 458 F2d 927, 931 (7th Cir 1972) (letter to class members seeking their participation as named plaintiffs constituted "slight breach of ethics" but that misconduct was not serious and did not warrant dismissal of action); duPont Glore Forgan, Inc. v AT\&T, 69 FRD 481, 484 (S D NY 1975) (solicitation does not taint named plaintiffs' capacity to represent the class if they are otherwise adequate; class counsel responsible for the solitication had withdrawn from the case).

314 Model Code DR 2-107(A).

s1s Id. See also Model Code DR 5-103(A); Model Rule 1.5(e). 
tiff (another unnecessary impediment to class and derivative litigation that would be obviated if "Jane Doe" or "Richard Roe" complaints were allowed). Such attorneys expect to be compensated for providing the representative plaintiff in an amount greater than would be justified by their time records alone. Other attorneys may front the costs of the litigation at their own expense; they may demand extra compensation for this service to account for the time value of money and the risk of nonrepayment. ${ }^{316}$

To date there appear to be no cases disqualifying counsel for engaging in unethical fee-splitting. However, the Second Circuit's recent Agent Orange ${ }^{317}$ decision raises the prospect that motions to disqualify based on alleged breaches of ethical rules may be seen in the future. Because the court in Agent Orange required immediate disclosure of any fee-splitting arrangements, defendants will have more information in future cases on which to base a challenge to the plaintiffs' attorneys' ethics on grounds of fee-splitting. We hope that courts will reject such challenges; the alleged ethical impropriety has nothing to do with whether the attorneys in question can function as adequate advocates for the plaintiff class.

\section{Appearance of Impropriety}

A further ground for challenging plaintiffs' counsel, which has proved successful for defendants in several cases, is the claim that counsel's behavior has created an "appearance of impropriety" that either aggravates other ethical violations or operates as an independent disqualifying factor. The ethics rule at issue states that "[a] lawyer should avoid even the appearance of professional impropriety." 318

Cases in which the attorney has been criticized for creating an appearance of impropriety are often intertwined with questions of typicality of the named plaintiff. A leading case is Kramer $v$ Scien-

s18 See In re "Agent Orange" Product Liability Litigation, 611 F Supp 1452, 1454 (E D NY 1985), rev'd, 818 F2d 216 (2d Cir 1987) (lawyers in consortium agreed that members who advanced funds to support the litigation would receive threefold reimbursement from pool of attorneys' fees generated upon successful completion of the litigation); Wolfram, 47 L \& Contemp Probs at 303 (cited in note 45) ("Fee-splitting and kindred practices probably are rather widely engaged in by plaintiff's lawyers in certain clientless litigation such as class actions for damages. ... Related practices include rather blatant and self-interested 'brokering' of power positions in one case in return for power in another-always with a larger share of the fee award ultimately in view.").

${ }^{317}$ In re "Agent Orange" Product Liability Litigation, 818 F2d 216 (2d Cir 1987).

s18 Model Code Canon 9. There is no direct analog for this canon in the newer Model Rules. 
tific Control Corp. ${ }^{319}$ At issue was whether a named plaintiff, an attorney, could retain one of his own law partners as class counsel. The court disqualified the attorney on the ground that serving as class counsel would create the appearance of impropriety because, among other things, the attorney-plaintiff had an interest in the attorney's fee that conflicted with his interest in the class recovery. ${ }^{320}$

The results in Kramer and similar cases are extremely questionable. The close connection between the representative plaintiff and the plaintiffs' attorney did give the representative plaintiff an interest in the attorney's fee that differed substantially from his interest as class representative. But for reasons already discussed, this result is not particularly problematic. ${ }^{321}$ The alternative to having a close associate of the attorney serve as representative plaintiff is to have a stranger do so, and in the large-scale, smallclaim class and derivative suit, the named plaintiff cannot be expected to monitor the attorney. The attorney's actions are unlikely to be affected by the nature of the representative plaintiff. That a close relationship between attorney and client would give rise to public obloquy against the legal profession ${ }^{322}$ seems far-fetched at best. The argument that the attorney creates an "appearance of impropriety" when she represents some close associate in largescale, small-claim class or derivative litigation seems extraordinarily weak.

At the same time, implementation of the Kramer rule is likely to harm the interests of the class members or corporation it was ostensibly designed to protect. In Kramer itself the motion to disqualify counsel was almost certainly a defense counsel litigation tactic. Rather than moving to disqualify counsel immediately, the defendant waited until the litigation was relatively well-advanced. It is hardly likely that the defendant's motives were to protect the absent class members. Instead, the defendant was apparently attempting to obtain the maximum settlement leverage by threatening counsel at a time of greatest vulnerability. After Kramer, this kind of litigation tactic is more likely to be successful, resulting in

${ }^{319} 534$ F2d 1085 (3d Cir 1976).

${ }^{320}$ Id at 1092. See also Zylstra v Safeway Stores, Inc., 578 F2d 102, 104 (5th Cir 1978); Fechter v HMW Industries, 117 FRD 362 (E D Pa 1987); Bachman v Pertschuk, 437 F Supp 973, 977 (D DC 1977); Flamm v Eberstadt, 72 FRD 187, 190 (N D Ill 1976), aff'd as Susman v Lincoln American Corp., 587 F2d 866 (7th Cir 1978).

${ }^{321}$ See text at notes 208-12.

${ }^{322}$ See Zylstra, 578 F2d at 104-05 ("the public suspicion of such a conflict is sure to outweigh any public benefit from having that attorney continue"). 
less favorable settlements for the class or corporation and reducing the amount of class and derivative litigation brought in the first place.

In our view, courts should be extremely cautious about disqualifying counsel for an inappropriately close relationship with the named plaintiff. We can conceive of few circumstances in which the alleged "appearance of impropriety" would be so serious as to justify the costs to the class or the corporation of disqualification. What matters is whether the representation is likely, as a practical matter, to be harmed by the relationship between attorney and named plaintiff. Because the harm to the putative clients is usually entirely speculative, a district court should ordinarily refuse to disqualify an attorney on this ground.

\section{E. Appropriate Use of Ethical Considerations}

We do not mean to suggest that a court should never consider an attorney's ethical behavior in determining whether or not the attorney is a proper advocate for the class or corporation. There are obviously many situations in which the attorney's ethics should be taken heavily into account. For example, the attorney may have some prior relationship with the defendant that raises questions either about the confidences of a former client or about potentially lingering loyalties to a current adversary. The attorney could have misused client funds or engaged in conduct prejudicial to the factfinding process in other cases. ${ }^{323}$ Given that the putative clients cannot effectively monitor the attorney in class and derivative cases, it would seem fitting for the trial court to examine the attorney's actions on its own initiative if there are grounds to suspect that the attorney will not prove trustworthy in the ongoing case.

\section{An Auction Approach to Class Action and Derivative Litigation}

So far we have analyzed the existing regulatory structure and made suggestions for reform within that structure. We turn now to a more dramatic suggestion for reform: the legal system should experiment with an auction approach to large-scale, small-claim class and derivative suits. ${ }^{324}$ 1986).

323 See Wagner v Lehman Brothers Kuhn Loeb, Inc., 646 F Supp 643, 656 (N D III

324 Although an auction approach to class and derivative litigation has been suggested previously, the following is, to the best of our knowledge, the first extended discussion of the 


\section{A. Description of an Auction Model}

As we envision it, an auction for the claims in a class action or derivative suit would look something like the following. A lawsuit is filed containing class or derivative allegations, or containing allegations that clearly support class relief. At this point the judge can make an initial investigation of the case to determine whether it would be appropriate for auction treatment. The judge should be authorized to conduct a limited examination of the defendant in order to obtain necessary information. The judge could ask the attorney who filed the initial lawsuit to cooperate with this investigation on the understanding that if the case is auctioned to another attorney, the original attorney would receive fair compensation for her efforts and search costs. The judge could also appoint a master to further investigate the facts.

The judge's determination of whether the case is suitable for auction should turn on several factors. First, are there a large number of small claimants-in other words, does the case fall into our category of large-scale, small-claim litigation? Second, how many lawsuits have been filed to redress the alleged wrongs? If only one suit has been filed, this would tend to count against auction treatment. But if several lawsuits are filed, as is typical in large-scale, small-claim litigation, this factor supports auction treatment. Third, are the claims involved sufficiently definite to warrant an auction at this time? If the claims are diffuse, indefinite, and poorly defined, an auction might be unsuccessful; the court might then be inclined to wait until further clarity has been achieved in the ongoing lawsuit. Fourth, are there any other factors that counsel against auction treatment, such as important individualized issues that would require extensive participation by class members?

If the judge determines that auction treatment is appropriate, she would then define the claim involved as precisely as possible.

idea. Leo Herzel and Robert Hagan briefly suggest the possibility of an auction in their outstanding article on plaintiffs' attorney fees. Leo Herzel and Robert K. Hagan, Plaintiffs' Attorneys' Fees in Derivative and Class Actions, 7 Litigation 25, 27 (Winter 1981). Our analysis generally accords with that of Herzel and Hagan, although it is more developed. John Coffee also mentions the possible value of an auction approach, see Coffee, 86 Colum L Rev at 691-93 (cited in note 4), but dismisses the idea out of hand because of difficulties in compensating the attorneys who frame and initiate the litigation. Janet Cooper briefly mentions the Oracle litigation in her unpublished working paper, Do the Merits Matter? at 208 (cited in note 3), but does not discuss the idea at any length. These are the only commentators who have ever mentioned the possibility of the auction concept.

For an interesting suggestion that a debtor's legal claim against a third party be auctioned in the bankruptcy context, see Matter of Central Ice Cream Co., 836 F2d 1068, 107273 n 3 (7th Cir 1987). 
The court would issue the definition of the claim with the caveat that further modifications or revisions may become necessary as the litigation progresses and that the asset being sold is the claim as defined subject to such potential future modifications. The judge would then cause notice to be posted in suitable newspapers and other periodicals announcing that the claim will be auctioned off, stating where further information about the claim (such as a formal bid package) can be obtained, and setting forth bidding procedures. The most workable bid procedure would seem to be a standard sealed-bid protocol with the claim going to the highest bidder. To simplify the process, all bids would be in cash or the equivalent. The judge, at her discretion, might state a minimum bid in order to prevent an excessively low sale price. There would be no need for the named plaintiff to have any involvement in the auction, nor should the bidders be required to provide their own named plaintiffs. Indeed, for reasons already discussed, ${ }^{325}$ a named plaintiff is entirely unnecessary in large-scale, small-claim litigation; a "Jane Doe" or "Richard Roe" complaint brought on behalf of absent class members or shareholders should suffice.

After allowing a suitable period of time for potential bidders to investigate the claims, the judge would award the claim to the highest bidder. That bidder, not necessarily an attorney or law firm, would then pay the bid amount to the court. The judge would deduct expenses, such as the costs of investigation and publicity, and would, at her discretion, deduct an amount she considers appropriate to compensate the lawyers who initially filed the litigation, or who assisted the judge in investigating the claim and packaging it for sale.

The judge would then handle the distribution of the remaining funds. In derivative litigation, the distribution would ordinarily be a simple payment into the corporate treasury. In class action litigation, the judge would order notice to those class members who could be identified with reasonable certainty. The court could again utilize a master, or "retain" one of the lawyers who has been involved in framing the litigation, to identify the absent class members. Plaintiffs would be asked to submit proofs of claim to the degree that such proofs would be necessary in order to establish damages in a trial on the merits. The court would then distribute the funds as in standard class action litigation-but the funds would come before trial. 
Meanwhile, the winning bidder would succeed to the rights of the plaintiffs who have not opted out. If the defendant's submission turns out to be the winning bid, the defendant could simply move for dismissal of the action with prejudice. There could be some technical difficulties here-a federal court might be said to lack jurisdiction over an action brought by a party against itself-but these could no doubt be finessed by, for example, an order dismissing the lawsuit issued after the judge has opened the bids and determined the defendant to be the winner, but before the court has actually caused the sale to be consummated by formally accepting the winning bid. To facilitate this result, the defendant's bid could contain a request to the court to dismiss the action with prejudice in the event that the defendant wins the auction. In such a case, the court would still follow the above procedure to distribute the fund to the claimants.

If a bidder other than the defendant wins the auction, the winning bidder would then prosecute the claim. We would assume that the litigation would appear from the outside much like standard class or derivative litigation. For the most part, the litigation would then be expected to closely resemble standard litigation between contesting parties, with a few wrinkles that we address below.

\section{B. Advantages of the Auction Approach}

There are a number of potential advantages of the auction approach. Most saliently, it may overcome the agency costs that plague class and derivative litigation in its current guise. ${ }^{326}$ The winning bidder becomes the owner of the claim, and therefore acts as its own agent. ${ }^{327}$ The winning bidder, in other words, would

${ }^{326}$ Realistically, an auction would not totally eliminate agency costs because any largescale litigation will itself involve the division of labor, with the attendant costs of agency. However, the auction could be expected greatly to reduce agency costs by substituting a relationship in which monitoring and bonding are highly developed and effective for one in which these devices are virtually absent.

${ }^{327}$ Several commentators have noted the benefits, in terms of reducing agency costs, of selling claims to the attorney or some other party. See Robert Cooter, Toward a Market in Unmatured Tort Claims, 75 Va L Rev 383 (1989) (analyzing potential function of market for unmatured tort claims); Marc J. Shukaitis, A Market in Personal Injury Tort Claims, 16 J Legal Stud 329 (1987) (outlining significant advantages to victims from a market for personal injury tort claims); Miller, $16 \mathrm{~J}$ Legal Stud at 196-97 (cited in note 21) (agency costs in settlement would be largely absent if client could sell the claim to the attorney); Kevin M. Clermont and John D. Currivan, Improving on the Contingent Fee, 63 Cornell L Rev 529, 596-97 (1978) (sale of claim would overcome problems inherent in contingent fee arrangements). 
have the same incentives to litigate the claim as would the sole owner of a claim in traditional litigation. The principal advantage of reducing these agency costs is that the plaintiffs' attorney no longer has an incentive to engage in collusive settlements with the defendant. Rather, the winning bidder will seek to prosecute the action for all it may be worth. The benefits of the higher expected recoveries would, of course, be shared ex ante with the class members or the corporation, given that the bidder will have every incentive to share some of these anticipated gains with the class or corporation in the form of a higher initial bid in order to raise the probability of winning the auction.

The auction device could reduce transactions costs. It would no longer be necessary, for example, for the court to review the substance of settlements or fee requests. If after auction the litigation resulted in a settlement, it would simply be filed in court as in standard litigation. No judicial scrutiny would be required because the winning bidder as owner of the claim has optimal incentives to obtain the best possible outcome, and there are no absent parties whose rights could be prejudiced by the litigation. Issues of attorney fees would arise only in fee-shifting cases, where the settlement would presumably include defendant's liability for fees. Again, no problems of simultaneous negotiations over fees and merits relief would arise, thus obviating any need for judicial scrutiny of negotiated fee awards. No judicial determination of fees would be required at all in common fund cases, where the winning bidder would pay its own attorneys.

Transactions costs could also be reduced in the conduct of the litigation on the plaintiffs' side. The winning bidder could be expected to conduct the litigation through a single law firm or team, in contrast with the current system in which the plaintiffs' side is typically represented by a loose consortium of plaintiffs' firms under the general coordination of lead counsel. Consolidation of the litigation within a single firm could be expected to reduce the high costs of monitoring, coordination, and duplicative work that characterize the current conduct of plaintiffs' class and derivative litigation. Of course, an auction of the claim would itself entail transactions costs. The claim must be defined, the offer must be brought to the attention of potential bidders, and the asset under sale must be investigated by bidders. We think, however, that these costs will be less than those of the current system.

Another advantage of the auction procedure is that, as in the case of any market arrangement, it tends to direct the asset under sale to the most efficient (i.e., highest-valuing) user. This would 
represent a major change from the present system, which contains no meaningful guarantee that the litigation will be conducted by the most qualified attorney. Indeed, in some contexts (such as securities fraud litigation) the system appears subject to pervasive problems of entrenchment by established firms occupying relatively well-defined positions in a long-standing pecking order. ${ }^{328}$ Other things equal, we would expect the winning bidder in an auction to be better qualified and more competent at prosecuting the claim than the losing bidders. Better representation would presumably benefit the class members or the corporation because they can be expected to share in some of the gains from the improved representation in the form of higher bids at the auction.

Finally, an auction should enhance the private enforcement of the law by replacing a party whose interest is only in the profits flowing from the award of fees (the plaintiffs' attorney under the current regime) with a party with a bona fide interest in maximizing the net return to the claim for a party (the winning bidder of the auction process). Potential defendants could be expected to adjust their primary conduct accordingly in order to equilibrate their marginal costs of expected litigation losses with their marginal costs of complying with the law. Assuming that the underlying legal principles are worthy of enforcement in the public interest, ${ }^{328}$ enhancement of the private enforcement of the law would appear to represent a significant social benefit.

\section{Problems with the Auction Approach}

We do not mean to imply that an auction approach is a panacea for the problems attending large-scale, small-claim litigation. It is not. There are a number of obvious difficulties with the approach, both in theory and in practice, and undoubtedly other difficulties would arise if the approach were implemented. In our view, these difficulties are not insurmountable and do not refute the desirability of experimenting with an auction approach. We are confident that the benefits of an auction process in large-scale, small-claim litigation outweigh the costs in a wide range of cases. ${ }^{330}$

First, defining the scope of the claim being auctioned would be difficult in many cases. To be sure, class and derivative litigation

s28 See note 197 and accompanying text.

329 This is a matter on which we take no position. See note 19 and accompanying text.

${ }^{330}$ We recognize that an experiment with an auction approach might lead to the conclusion that reform of the existing system-according to our suggestions in the preceding sections of this Article-may be the best we can do in an imperfect world. 
eventually $d o$ result in outcomes, whether settlements or judgments, in which the claim is sufficiently defined as to establish claim preclusion against subsequent litigation. But these outcomes occur after the litigation has been underway for some time and the scope of the claims has been refined as a result of discovery. The auction procedure would require that the claim be defined with reasonable precision at the outset.

This difficulty is not overly serious, however. As mentioned already, it should be open to the trial court either on its own authority or in cooperation with the initial plaintiffs' counsel to conduct limited discovery of the defendant for purposes of defining the claim, as well as to engage in further investigation as necessary. The trial court could also make clear that the "claim" being sold was only provisionally defined, and that additional refinements might be necessary as the litigation progressed. These refinements might be either beneficial or detrimental to the winning bidder at the auction, but there is no reason to think that they would be biased in either direction. The only problem with maintaining the definition of the asset being sold in somewhat fuzzy fashion would appear to be that doing so increases the riskiness of the litigation to the winning bidder. The indeterminate nature of the claim would probably reduce somewhat the amount risk-averse bidders would be willing to pay for the assets. Although this is a real cost of an auction procedure, it is not enough in itself to justify abandoning the experiment.

Second, the auction procedure would be ineffective to the extent that the bidders engaged in collusion to keep prices low. The defendant will always be a potential bidder who might be expected to keep the other bidders at least reasonably within bounds. However, in the case of the plaintiffs' securities bar in particular, which is currently dominated by a relatively small number of firms, the dangers of collusion should not be ignored. ${ }^{331}$ The danger of collusion would seem relatively slight; however, the threat of criminal penalties for price-fixing, not to mention disbarment, should ordinarily be sufficient to deter the practice.

Third, there may be too few bidders, or too few bidders with sufficient finances to make adequate bids. The amounts in controvery in large-scale, small-claim litigation can be enormous, running into the millions or even tens of millions of dollars. Obviously

s32 This is not to say, of course, that there is any reason to expect the excellent firms in the plaintiffs' securities bar to engage in improper behavior. Collusion is always more probable when there are a small number of participants in a market. 
the number of bidders at such rarefied price levels might well be fewer than for assets of lesser value. If the number of bidders falls too low, the value of the auction may be dissipated because the bidders will pay too little for the claim. ${ }^{332}$

Again, however, this problem may not be as serious as it appears at first blush. The auction should be open to all bidders, including defendants, whether or not they are lawyers or law firms. ${ }^{333}$ Venture capital firms, wealthy investors, specialized corporations or limited partnerships, among others, should be allowed full participation rights. Increasing the number of bidders in this fashion should enhance the auction prices. Further, especially if an auction procedure were instituted, we would expect to see the development of creative financing structures to provide funds for bidders with legal expertise. These structures, which might include securitized equity or limited partnership offerings, could provide financing that would not otherwise be available to bidders through sources such as banks or other financial intermediaries. Although creative financing of litigation faces potential ethical limitations ${ }^{334}$ and has not been particularly successful when attempted in the past, ${ }^{335}$ the

${ }^{332}$ Virtually no information exists on how much bidders would be willing to pay for unliquidated damage claims of this magnitude. There is some indication that attorneys would be able to raise substantial funds to support the litigation of large cases, if the courts were to permit them to do so. See, for example, In re "Agent Orange" Product Liability Litigation, 818 F2d 216, 218-19 (2d Cir 1987) (six members of plaintiffs' attorneys' consortium agreed to advance $\$ 200,000$ each-later raised to $\$ 250,000$ for five of the members-to fund massive product liability litigation; court invalidated arrangement because those advancing the money received a 300 percent return).

${ }^{333}$ See Herzel and Hagan, 7 Litigation at 27 (cited in note 324).

${ }^{334}$ See Vincent Robert Johnson, Ethical Limitations on Creative Financing of Mass Tort Class Actions, 54 Brooklyn L Rev 539 (1988). Recently a federal disctrict judge, in an unreported decision, dismissed a syndicated lawsuit on grounds of champerty-the practice of dividing awards in lawsuits with third-party investors. See Leslie Spencer, Some Call it Champerty, Forbes 72 (Apr 30, 1990) (describing dismissal of patent infringement case in which patent holder had raised $\$ 750,000$ to prosecute the suit by syndicating it to 32 investors).

s3s Perhaps the most notable failure was the attempt by a public interest group to launch a "Public Equity Corporation" by means of a registered stock offering of 480,000 shares of common stock at $\$ 5$ per share. See Comment, Financing the Market for Legal Remedies: The Public Equity Company Concept, 4 Class Action Rep 308, 310 (1975). The organizers stated that the funds raised would be used, among other things, to support public interest class action litigation. The offering, however, failed to attract the minimum number of initial subscribers and had to be cancelled.

More recent attempts to syndicate class action litigation have been less altruistic, and sometimes more sučcessful. See Spencer, Forbes at 72 (cited in note 334) (describing one syndicated lawsuit in which 44 individuals apparently received a return of $\$ 63$ million on an initial investment of $\$ 4$ million); Catherine Yang, Psst! Wanna Buy a Lawsuit?, Forbes 67 (May 19, 1986). 
existence of an auction mechanism might stimulate the development of more effective means for obtaining public financing.

Nevertheless, financing remains a potentially serious problem for the largest claims. If it turns out that such claims cannot be effectively sold at auction due to their size, the regulatory system could experiment with an auction format that does not involve the complete sale of the claim. For example, the court could auction the right to litigate the claim, but not the claim itself, to the attorney who offers to do so at the lowest percentage of the recovery. Indeed, one federal district court judge recently conducted an auction for lead counsel rights in a large securities class action, with apparently successful results. ${ }^{336}$ This approach would not require the attorneys to put forward any cash to obtain the right to litigate the claim, and would have the advantages of opening up the market for plaintiffs' attorneys and reducing the systematic overcompensation feature of the percentage-of-the-recovery approach..$^{337}$ However, this approach would reintroduce a substantial element of agency costs, in that the winning attorney would have an incentive to settle early in order to obtain a larger profit on the fee. ${ }^{338}$ The competence or financial qualifications of the low bidder in this type of auction might also be suspect.

An alternative would be for the court to set a percentage fee-say 30 percent-and then conduct a cash auction for the right to represent the plaintiff class or corporation and to recover the fee out of the common fund. The cash bids required at such an auction would be far lower than the bids required in an outright sale of the claim, thus mitigating the financing problem. At the same time, the requirement that the attorney front cash aligns the attorney's interests with those of the absent class members better than in the case of an auction based on percentage bids. It also tends to substantiate the attorney's competence and financial resources.

s36 See In re Oracle Securities Litigation, 131 FRD 688 (N D Cal 1990) (court instructed teams of lawyers competing for lead counsel designation to submit competitive litigation budgets; when attorneys refused to compete and filed joint budget, the court rejected the proposal and insisted on in camera competitive bids, including statements of qualifications and percentage of the judgment counsel would accept as a fee). The court received bids from four firms and chose one as representing the best value for the class. See In re Oracle Securities Litigation, 132 FRD 533 (N D Cal 1990).

See also Bennet A. McConaughy, Back to the Future: Use of Percentage Fee Arrangements in Common Fund Litigation, 12 Puget Sound L Rev 43, 65-66 (1988) (recommending that plaintiffs' counsel be required to file a fee agreement with the complaint stating the lowest percentage of the recovery she will accept, but not specifically advocating an auction based on the percentage bids).

s37 See notes 68-70.

ss8 See note 71 . 
Nevertheless, a cash auction for the right to receive a specified percentage recovery would only partially mitigate the agency problem over the issue of settlement. Any approach that does not involve the complete auction of the claim will involve substantial agency costs. In large cases, however, these costs may be preferable to the costs of an auction in which the bidders are too few or inadequately financed.

Let us return to the analysis of the complete auction of the claim, in order to discuss a fourth problem with this procedure-namely, ensuring the cooperation of the plaintiff class in the proof of the claim. ${ }^{339}$ The problem here is particularly acute if-as would be common in securities litigation, for example-the damages suffered by each class member will depend on individualized facts about when and how much she traded. We mentioned above that in such cases the class members could be required to submit a proof of claim in order to obtain their share of the auction results, and those proofs would be used by the auction winner to establish its own claim. There could, however, be thorny legal problems with this procedure if the defendant chose to contest the claim on the ground that the proofs of claim were hearsay or that the defendant had a constitutional right under the due process clause to crossexamine class members as to whether they actually incurred the damages they claimed. The defendant might also seek to examine individual class members as to the existence of any individualized defenses, such as lack of reliance in a fraud-on-the-market case. ${ }^{340}$ These class members could be subpoenaed, of course, but their cooperation would be in doubt if they no longer had a viable economic stake in the outcome. A court would need to develop innovative procedures for dealing with these difficulties.

Another problem with the auction approach is that of compensating the plaintiffs' attorney who first identified the claim. Under the current regulatory system, the "first mover" receives some compensation for identifying and researching the claim. Although the first attorney to file is rarely able to exclude other attorneys

\footnotetext{
s30 Problems of cooperation are emphasized as an impediment to the sale of legal claims in Danzon, 14 Bell $\mathrm{J}$ Econ at 223 (cited in note 47) (At the limit, a "profit-maximizing plaintiff could capture twice the value of the claim by selling it first to his attorney for its expected value and then selling his services to the defense to save them that expected value."). Danzon's concerns, however, appear more relevant to personal injury lawsuits with single plaintiffs than to large-scale, small-claim class action litigation with multiple plaintiffs similarly situated for most purposes. The cooperation problem is not present in the case of derivative litigation.

340 See Basic, Inc. v Levinson, 485 US 224 (1988).
} 
from participating in large-scale, small-claim suits, she at least has a share in the litigation and a claim to a position of some importance in the plaintiffs' consortium, especially if the claim was not widely publicized prior to the filing of the complaint. An auction approach could deter first movers by threatening to deprive them of any benefit from their research into the case.

However, this problem would not appear to be insurmountable. The contributions of first movers in large-scale, small-claim litigation can easily be overstated. It would appear that in most cases, the existence of the claim is widely known among the plaintiffs' bar prior to filing, as a result of prior government action ${ }^{341}$ or because of newspaper or other publicity. In any event, the first filer could simply receive some sort of quantum meruit award for her services in the litigation, to be taken out of the winning bid. The judge could make such awards as a matter of discretion and, in determining the amount to award, could examine the likelihood that the suit would not have been brought in the absence of the first mover's services in identifying and framing the litigation and filing the initial complaint. Although the rewards to the first mover would not be set very accurately under this system, they would seem to be no worse, in this regard, than the current arrangements for compensating first filers. ${ }^{342}$

The auction approach would also face inevitable problems of multidistrict litigation. If suit is filed in one federal district court, the trial court would not have the power to conduct a nationwide auction that would preclude the prosecution by plaintiffs' attorneys of the same claim in other districts. The auction method presupposes the aggressive use of the consolidation procedures set forth in the Manual for Complex Litigation. But even if these procedures effectively consolidate litigation as between federal district courts, it is unclear how the auction procedure would deal with cases in which class or derivative claims are filed simultaneously in state as well as federal courts. ${ }^{343}$ Because of the critical importance

${ }^{341}$ See John E. Kennedy, Securities Class and Derivative Actions in the United States District Court for the Northern District of Texas: An Empirical Study, 14 Houston L Rev $769,809,824$ (1977) (at least one-third of securities class actions studied follow SEC proceedings or bankruptcy filings); Benjamin S. DuVal, Jr., The Class Action as an Antitrust Enforcement Device: The Chicago Experience (II), 1976 Am Bar Found Res J 1273, 1282 (high incidence of private class actions following on heels of government antitrust enforcement proceedings).

s42 We disagree, therefore, with Professor Coffee, who views the problem of compensating first movers as fatal to the auction approach. See Coffee, 86 Colum L Rev at 691-93 (cited in note 4).

sis Under current law, a state action cannot be consolidated with a federal action by the 
of the size of the claim to the auction process, this state-federal conflict, although also extant in the current regulatory regime, presents more significant problems in the auction context.

In jury cases that have been auctioned, defendants would undoubtedly attempt to bring the fact of the auction to the attention of the jury, on the theory that a large corporation or other entity owning a $\$ 10$ million claim purchased in a speculative auction is a considerably less appealing plaintiff than thousands of innocent small individuals. Because this is indeed likely to be an accurate assessment of the jury's response, we see no reason to bring the fact of the auction to the jury's attention. The presence of a new real party in interest does not change the underlying facts or law of the case, and should not have any relevance to the jury's deliberations.

Finally, an auction approach would face difficulties in civil rights and other cases in which injunctive relief is the primary relief sought. Because the bidders at such auctions generally expect no pecuniary benefit from the litigation other than an award of attorney's fees if the suit is successful, it may be necessary at a minimum to exclude defendants from any participation in such auctions. An auction approach may simply be infeasible in injunctive cases where ideology is a major factor.

Although the problems we have identified counsel caution in implementing an auction procedure, the auction approach also promises significant benefits. These potential benefits support at least preliminary experimentation with the idea.

\section{Conclusion}

In attempting to explain how his earlier philosophy had fallen into egregious error in its account of the meaning of a word, Ludwig Wittgenstein remarked that "a picture held us captive." Our analysis of the regulatory system applicable to class and derivative cases likewise suggests that an erroneous picture has captured the imaginations of those who craft the rules in this area. The picture is that of the traditional lawsuit in which the client actively attempts to monitor and control the activities of the attor-

Federal Multidistrict Judicial Panel unless the defendants remove the action to federal court. Federal injunctions against parallel state litigation are generally barred by the AntiInjunction Act, 28 USC $\$ 2283$ (1982). See Coffee, 54 U Chi L Rev at 910-11 (cited in note 4).

344 Ludwig Wittgenstein (G.E.M. Anscombe, trans), Philosophical Investigations โI 115 at $48 \mathrm{e}$ (Macmillan, $3 \mathrm{~d}$ ed 1958) (emphasis in original). 
ney. Although the regulations applicable to class and derivative litigation are typically justified on the ground that client monitoring is absent in this setting, too often the regulatory system has not gone far enough in recognizing the unique dynamics of class and derivative litigation, especially in large-scale, small-claim cases.

This Article has attempted a comprehensive analysis of the economic incentives facing plaintiffs' attorneys in class action and derivative litigation. Drawing on the theory of agency costs, we demonstrated that the standard devices for reducing conflicts of interest between principal and agent-monitoring, bonding, and incentives-are almost totally ineffective in large-scale, small-claim class and derivative suits. Nor are the standard regulatory responses for overcoming the agency problem in traditional litigation settings effective in the class and derivative context.

Three regulaiory programs are specifically designed to control agency costs in the class action and derivative litigation setting: regulatory devices for allocating litigating authority away from the plaintiffs' attorney and into the hands of others involved in the process (absent class members, corporate management in derivative suits, the representative plaintiff, and the court itself); regulation of the named plaintiff under the rules for typicality of claim and adequacy of representation; and challenges to the qualification of the plaintiffs' attorney on grounds of ethical violations. These systems of rules, however, are often ineffective and sometimes selfdefeating. Whether this regulatory failure is due to a conceptual block on the part of the policymakers, or to some unspoken agenda of hostility to class and derivative suits, the result is the same: the utility of the class action and derivative devices as mechanisms for the private enforcement of the law is undermined.

At various points in this paper we have made concrete suggestions for improvements in the existing regulatory system. The essential thrust of each of these suggestions has been the same: abandon the attempt to assimilate class and derivative litigation with the picture of traditional lawsuits, and instead devise sensible rules crafted to account for the fact that it is the plaintiffs' attorney who controls such litigation. In addition to proposing a variety of concrete doctrinal reforms, we suggested that many current problems could be mitigated if plaintiffs' attorneys were not required to provide an actual named plaintiff as their ticket into the litigation.

An auction approach to class and derivative claims promises a number of benefits, most importantly reductions in agency costs and increases in the efficiency of private enforcement of legal 
norms. The approach is subject to a number of potentially serious problems. Yet, particularly in light of the current regulatory failure, the auction idea has sufficient merit to warrant at least a limited experiment to determine whether such a system would indeed be workable on a larger scale. 